\title{
1 Skepticism in the Philosophical Tradition
}

\subsection{On Sextus Empiricus' Outlines of Pyrrhonism}

Pyrrhonian skepticism as a philosophical idea is named after Pyrrho of Elis (c. 365-275 BCE). Pyrrho left no writings of his own (at least none that have survived) but what is known about his life is that he participated in the campaigns of Alexander the Great, including those in India, and lived to see Alexander's demise and the dissolution of his empire. The mainly anecdotal information that has been passed down represents the consequent realization of his skeptical philosophy in everyday life mostly in a polemical, caricaturing manner. ${ }^{4}$ Pyrrhonism was presumably developed into a theory by Aenesidemus, a first-century philosopher based in Alexandria, ${ }^{5}$ but its most famous proponent was another Alexandrian - the Greek physician and philosopher Sextus Empiricus, who lived over 400 years after Pyrrho. Sextus Empiricus' work Outlines of Pyrrhonism (Pyrrhōneioi hypotypōseis) provides the most comprehensive and detailed account of Pyrrhonian skepticism yet found. In addition to Outlines, his preserved works comprise the eleven books Against the Mathematicians (Pros mathematikús or Adversus mathematicos; usually the Latin version of the title is used). The first section critically examines the individual arts and sciences of grammar, rhetoric, geometry,

4 For instance, the accounts are legion that he, "[...] leaving nothing to the arbitrariness of the senses[;]", was not "[...] going out of his way for nothing, taking no precaution, but facing all risks as they came, whether carts, precipices, dogs or what not [...]" (cf. Diogenes Laertius, Vitae et sententiae philosophorum IX,62 [Diogenes Laertius, Lives of Eminent Philosophers (GreekEnglish), trans. Robert Drew Hicks, 2 vols., London/New York 1925, vol. 2, pp. 474 f.]); the following anecdote, documenting the skeptical serenity, is also famous: "When his fellow-passengers on board a ship were all unnerved by a storm, he kept calm and confident, pointing to a little pig in the ship that went on eating, and telling them that such was the unperturbed state in which the wise man should keep himself" (Diogenes Laertius, Vitae philosophorum IX,66 [Lives of Eminent Philosophers, vol. 2, pp. 480 f.]). When he was in the retinue of Alexander the Great in India, he is said to have come into contact with Indian ascetics - called by the Greeks

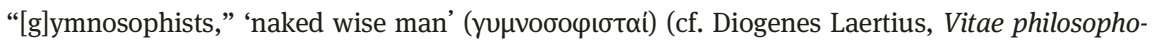
rum IX,61 [Lives of Eminent Philosophers, pp. 474 f.]); for possible influences and parallels as well as for the related research, cf. Richard Bett, Pyrrho, His Antecedents, and His Legacy, Oxford 2000, pp. 169-178; with regard to Pyrrho of Elis, see also, among others, Svavar Hrafn Svavarsson, "Pyrrho and Early Pyrrhonism," in: Richard Bett (ed.), The Cambridge Companion to Ancient Scepticism, Cambridge/New York 2010, pp. 36-57.

5 See Malte Hossenfelder, Die Philosophie der Antike 3: Stoa, Epikureismus und Skepsis, in: Wolfgang Röd (ed.), Geschichte der Philosophie, 13 vols., Munich 1976-2014, vol. 3 (1985), pp. $147 \mathrm{f}$.

Ә Open Access. (C) 2019 Leonie Pawlita, published by De Gruyter. (cc)BY-NC-ND This work is licensed under a Creative Commons Attribution-NonCommercial-NoDerivatives 4.0 International License.

https://doi.org/10.1515/9783110660586-002 
arithmetic, astronomy, and music (Books I-VI), and the second section (Books VII-XI) explores dogmatic philosophy (logic, physics, and ethics), thus broadening the discussion of the Outlines' books three and four.

Sextus Empiricus begins the first book of Hypotyposes (the second and third books deal with "statements of the Dogmatists") by declaring that in the search for truth one can either claim to have found it (the Dogmatists), believe that it is unattainable (the Academic skeptics), or maintain that although the truth has not yet been found, one is committed to continue searching for it (the Pyrrhonian skeptics). ${ }^{6}$ From the beginning Sextus makes it clear that his work is descriptive, but also sets out the subjective-relative orientation typical of Pyrrhonism: "[O]ur task at present is to describe in outline the Sceptic doctrine, first premising that of none of our future statements do we positively affirm that the fact is exactly as we state it, but we simply record each fact, like a chronicler, as it appears to us at the moment." ${ }^{7}$

6 Sextus Empiricus, Pyrrhoneion Hypotyposeon/Outlines of Pyrrhonism I, 1-4: "The natural result of any investigation is that the investigators either discover the object of search or deny that it is discoverable and confess it to be inapprehensible or persist in their search. So, too, with regard to the objects investigated by philosophy, this is probably why some have claimed to have discovered the truth, others have asserted that it cannot be apprehended, while others again go on inquiring. Those who believe they have discovered it are the 'Dogmatists,' specially so called-Aristotle, for example, and Epicurus and the Stoics and certain others; Cleitomachus and Carneades and other Academics treat it as inapprehensible: the Sceptics keep on searching. Hence it seems reasonable to hold that the main types of philosophy are three-the Dogmatic, the Academic, and the Sceptic" (Sextus Empiricus, Пupṕóveıo

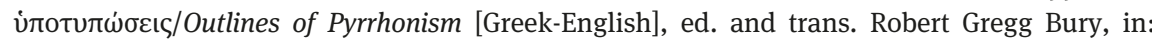
Sextus Empiricus, ed. and trans. R. G. Bury, 4 vols., London/Cambridge, MA 1933-1949, vol. 1, 3rd ed. 1961, p. 2/3). Bury's Greek-English edition of the Outlines forms the textual basis used here. More recent English editions of the Hypotyposeis include: Sextus Empiricus, Outlines of Scepticism, trans. and ed. Julia Annas and Jonathan Barnes, Cambridge/New York 2000 (1st ed. 1994); The Skeptic Way: Sextus Empiricus's Outlines of Pyrrhonism, trans. and ed. Benson Mates, Oxford/New York 1996). With regard to the name of the skeptical school and the aspect

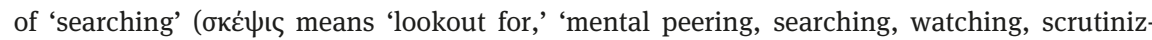
ing'), the following is later specified: 'The Sceptic School, then, is also called 'Zetetic'

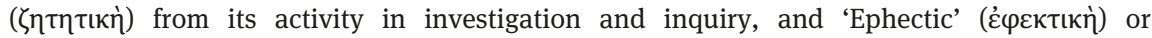
Suspensive from the state of mind produced in the inquirer after his search, and 'Aporetic' ( $\dot{\alpha} \pi о \rho \eta \tau \iota \kappa)$ or Dubitative either from its habit of doubting and seeking, as some say, or from

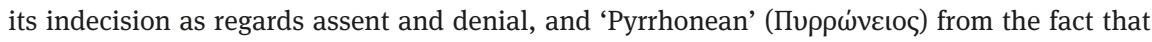
Pyrrho appears to us to have applied himself to Scepticism more thoroughly and more conspicuously than his predecessors" (Pyrr. Hyp. I, 7 [S. E., Outlines, pp. 4/5-6/7]).

7 Sextus Empiricus, Pyrr. Hyp. I, 4 (S. E., Outlines, pp. 2/3-4/5). 


\section{Sextus defines skepticism as}

[...] an ability, or mental attitude, which opposes appearances to judgements in any way whatsoever, with the result that, owing to the equipollence of the objects and reasons thus opposed, we are brought firstly to a state of mental suspense and next to a state of 'unperturbedness' or quietude. ${ }^{8}$

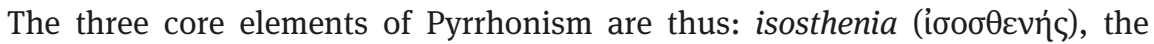
equally balanced co-presence of opposing arguments (establishing these oppo-

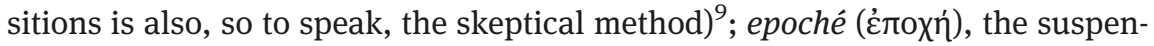
sion of judgement that follows from isosthenia; and ataraxia ( $\alpha \tau \alpha \rho \alpha \xi \dot{\prime} \alpha)$, a tranquil state of mind, the attainment of which is the goal of Pyrrhonism.

To begin with, let us consider "[t]he originating cause of Scepticism [. . .][:] the hope of attaining quietude."10 Ataraxia is the absence of tarachai ( $\tau \alpha \rho \alpha \chi \alpha \mathrm{l})$, disturbances, a freedom from inner restlessness and confusion, or to put it metaphori-

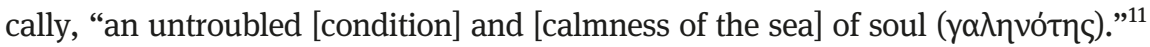
Ataraxia is not held to be a consistently achievable state - it represents no overarching goal, cannot be obtained by means of a zealous pursuit or the avoidance of such a pursuit, and it is not clear that ataraxia will lead to happiness:

We assert still that the Sceptic's End is quietude in respect of matters of opinion and moderate feeling ( $\mu \varepsilon \tau \rho ı \pi \alpha \dot{\theta \varepsilon ı \alpha}$ ) in respect of things unavoidable. For the Sceptic, having set out to philosophize with the object of passing judgement on the sense-impressions and ascertaining which of them are true and which false, so as to attain quietude thereby,

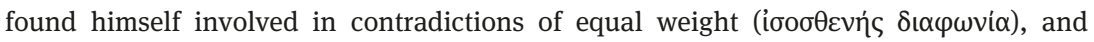
being unable to decide between them suspended judgement; and as he was thus in suspense there followed, as it happened, the state of quietude in respect of matters of opinion. For the man who opines that anything is by nature good or bad is forever being disquieted: when he is without the things which he deems good he believes himself to be tormented by things naturally bad and he pursues after the things which are, as he thinks, good; which when he has obtained he keeps falling into still more perturbations because of his irrational and immoderate elation, and in his dread of a change of fortune he uses every endeavour to avoid losing the things which he deems good. On the other

8 Sextus Empiricus, Pyrr. Hyp. I, 8 (S. E., Outlines, p. 6/7).

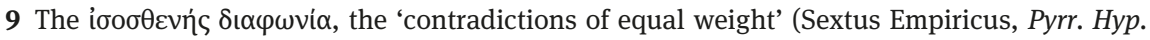
I, 26 [S. E., Outlines, p. 18/19]; see the following quote above). For the use of the term isosthenia, see Malte Hossenfelder, "Einleitung," in: Sextus Empiricus, Grundriß der pyrrhonischen Skepsis, introd. and trans. Malte Hossenfelder, 5th ed., Frankfurt am Main 2002, pp. 9-88, here p. 43.

10 Sextus Empiricus, Pyrr. Hyp. I, 12 (S. E., Outlines [cf. note 6], p. 8/9).

11 Sextus Empiricus, Pyrr. Hyp. I, 10 (S. E., Outlines, p. 8/9). 
hand, the man who determines nothing as to what is naturally good or bad neither shuns nor pursues anything eagerly; and, in consequence, he is unperturbed. ${ }^{12}$

The telos is thus consequently modified by Sextus to the effect that attaining ataraxy refers to 'matters of opinion,' that is to the realm of voluntary deci-

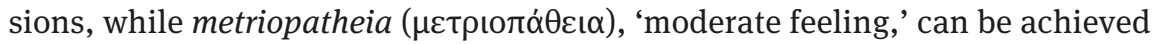
in respect to conditions that are unavoidable, such as pleasure/unpleasure or physical suffering (being cold, hungry etc.), in the sense that by accepting them as subjective realities, without subjecting them to a value judgment (e.g., without interpreting them as an objective evil), then there is 'moderate feeling,' that is, metriopatheia is achieved. ${ }^{13}$ The possibility of recognizing the truth of a judgment, including value judgements, is radically rejected.

Given 'the contradictions of equal weight' of conflicting opinions (isosthenia), all a skeptic can do is refrain from judgement; or pause, ${ }^{14}$ and 'by chance' ( nia like "a shadow follows its substance."15 For a skeptic, tarachai (perturbations)

12 Sextus Empiricus, Pyrr. Hyp. I, 25-28 (S. E., Outlines, p. 18/19).

13 Cf. Sextus Empiricus, Pyrr. Hyp. I, 29 f. ("We do not, however, suppose that the Sceptic is wholly untroubled; but we say that he is troubled by things unavoidable; for we grant that he is cold at times and thirsty, and suffers various affections of that kind. But even in these cases, whereas ordinary people are afflicted by two circumstances,-namely, by the affections themselves and, in no less a degree, by the belief that these conditions are evil by nature,the Sceptic, by his rejection of the added belief in the natural badness of all these conditions, escapes here too with less discomfort. Hence we say that, while in regard to matters of opinion the Sceptic's End is quietude, in regard to things unavoidable it is 'moderate affection"” [S. E., Outlines, p. 20/21]). With the concept of metriopathy, the demarcation to Stoa (an arbitrary re-evaluation of things and thus their controllability is not possible) and epicureism (pleasure can not be regarded as always available or unpleasure as always avoidable) becomes evident. (See also Hossenfelder, Stoa, Epikureismus und Skepsis [cf. note 5], pp. 152 ff.). 14 Cf., however, Hossenfelder's remark: “'Epoché' bedeutet zweierlei im Pyrrhonismus. Einmal meint es die Urteilsenthaltung, zum anderen das 'Innehalten' mit der Suche nach dem Wahren. [...] Es findet sich jedoch in den Quellen keine klare Scheidung der beiden Begriffe von Epoché. Sogar in der Definition, die Sextus von Epoché gibt, scheinen mir beide Begriffe vermengt zu sein [...]" [Epoché means two things in Pyrrhonism. On the one hand, it means the suspension of judgement; on the other hand, it means the 'pausing' in the search for what is true. (...) In the sources, however, there is no clear separation of the two concepts of epoché. Even in the definition that Sextus gives of epoché, both concepts seem to me to be mingled (...)] (“Einleitung” [cf. note 9], pp. 56 f.).

15 Cf. Sextus Empiricus, Pyrr. Hyp. I, 29: "So, too, the Sceptics were in hopes of gaining quietude by means of a decision regarding the disparity of the objects of sense and of thought, and being unable to effect this they suspended judgement; and they found that quietude, as if by chance, followed upon their suspense, even as a shadow follows its substance” (S. E., Outlines [cf. note 6], p. 20/21). 
consists of any pursuit of knowledge compelled by zeal. Knowledge must rather be sought in a state of distanced serenity and indifference. Unlike universal skepticism, however, which casts doubt on the very possibility of knowledge, Pyrrhonian skepticism maintains that the truth is not principally unrecognizable, it has simply not yet been recognized. Even doubt is relative and refers to the current state of each perceiving and judging individual. ${ }^{16}$

The Pyrrhonian attitude of epoché, suspension of judgment, is based on isosthenia, a methodology of continual questioning of absoluteness. For each statement, a counter-statement is deliberately sought. The acceptance of their equivalence leads to un-decidability, the inability to recognize the truth of a statement and give it preference over another.

Isosthenia, the equally balanced conflict of opposing opinions that leads to suspension of judgement, is grounded upon lists of skeptical arguments, the famous tropes (тро́лоь). The first list of these "skeptical modes" consists of ten tropes, ${ }^{17}$ which, according to Sextus, originate from Aenesidemus (1st century BCE). This is followed by another five "modes" or "tropes of suspension of judgement"18 attributed to Agrippa (1st century CE), two 'newer' tropes, ${ }^{19}$ and an account of "skeptical expressions." 20

The ten tropes of Aenesidemus focus on proving the skeptical position on the relativity of every judgment ("[...] the Mode of relation stands as the highest genus [...]") ${ }^{21}$ and use mostly perceptive impressions to argue relativity, namely that sense experience cannot provide a basis for certain knowledge. They thus challenge the Aristotelian conception of knowledge acquisition.

The first trope argues that due to differences among animals, they do not experience (see, hear, smell, feel) the same things in the same way, thus it is possible to make a statement about how a thing appears in each case, but not about how it 'really' is: "If, then, owing to the variety in animals their sense-impressions differ, and it is impossible to judge between them, we must necessarily suspend judgement regarding the external underlying objects."22

16 Hossenfelder, Stoa, Epikureismus und Skepsis (cf. note 5), pp. $156 \mathrm{f}$.

17 Sextus Empiricus, Pyrr. Hyp. I, 36-163 (S. E., Outlines [cf. note 6], pp. 24/25-92/93).

18 Sextus Empiricus, Pyrr. Hyp. I, 164-177 (S. E., Outlines, pp. 94/95-100/101).

19 Sextus Empiricus, Pyrr. Hyp. I, 178 f. (S. E., Outlines, pp. 100/101-102/103).

20 Sextus Empiricus, Pyrr. Hyp. I, 187-209 (S. E., Outlines, pp. 106/107-124/125).

21 Sextus Empiricus, Pyrr. Hyp. I, 39 (S. E., Outlines, p. 26/27).

22 Sextus Empiricus, Pyrr. Hyp. I, 40-78, here I, 61 (S. E., Outlines, pp. 26/27-46/47, here p. 36/37). 
The next trope expands the argument to the differences among human beings, saying that given that individual perception can differ from human to human, views about the same object can be contradictory. ${ }^{23}$

The third trope points to different perceptions within a particular human being. Since each of the senses has a different nature, the same individual can have contradictory reactions to the same impetus. For example, honey can appear pleasant to taste, but not to see, paintings can seem plastic to sight, but not to the sense of touch. Reason is therefore incapable of making a clear judgement and must exercise restraint: "But if the senses do not apprehend external objects, neither can the mind apprehend them; hence, because of this argument also, we shall be driven, it seems, to suspend judgement regarding the external underlying objects."24

The fourth trope focuses on how different states of being, such as sleeping or waking, drunkenness or sobriety, motion or rest, or the different stages of age and development, causes our perceptions and understanding to vary, making a reliable judgment about the 'reality status' of perception impossible, “[. . .] so that as a result of this Mode also we are brought to suspend judgement regarding the nature of external realities."25

The first four tropes illustrate the relativity of sensory perception by the perceiving subject. The next tropes include the relation to what is "judged," i.e. to the perceived objects, in order to argue against a universal validity of sense experience. $^{26}$

Thus, the fifth trope considers the changing positions, distances, and locations that cause a change in the perception of the object. For example, a ship viewed from a distance appears small and stationary, but appears large and in motion from up close; the same tower that seems round from afar round, seems square when near; the same oar that seems to be bent when in the water, is

23 See, e.g.: "But if the same objects affect men differently owing to the differences in the men, then, on this ground also, we shall reasonably be led to suspension of judgement. For while we are, no doubt, able to state what each of the underlying objects appears to be, relatively to each difference, we are incapable of explaining what it is in reality" (Sextus Empiricus, Pyrr. Hyp. I, 79-90, here I, 87 [S. E., Outlines, pp. 46/47-54/55, here pp. 52/53]).

24 Sextus Empiricus, Pyrr. Hyp. I, 91-99, quote I, 99 (S. E., Outlines, pp. 54/55-58/59, quote p. 58/59).

25 Sextus Empiricus, Pyrr. Hyp. I, 100-117, quote I, 117 (S. E., Outlines, pp. 58/59-68/69, quote p. 68/69).

26 See Sextus Empiricus, Pyrr. Hyp. I, 38 ("The first four of the ten Modes are subordinate to the Mode based on the subject [for the subject which judges is either an animal or a man or a sense, and existent in some condition]: the seventh and tenth Modes are referred to that based on the object judged: the fifth, sixth, eighth and ninth are referred to the Mode based on both subject and object” [S. E., Outlines, p. 24/25]). 
straight when in the air; the color of a dove's neck changes depending on one's position. Therefore:

[s]ince [...] all apparent objects are viewed in a certain place, and from a certain distance, or in a certain position, and each of these conditions produces a great divergency in the sense-impressions, as we mentioned above, we shall be compelled by this Mode also to end up in suspension of judgement. For in fact anyone who purposes to give the preference to any of these impressions will be attempting the impossible. ${ }^{27}$

The sixth trope argues that an object cannot be perceived in isolation and is always impacted by its surroundings. Thus: "[...] the same sound appears of one sort in conjunction with rare air and of another sort with dense air; and odors are more pungent in a hot bath-room or in the sun than in chilly air; and a body is light when immersed in water but heavy when surrounded by air."28

The seventh trope argues that the quantity and composition of the objects bring about a change in their perception. Individual grains of sand, for instance, are rough to the touch, but a pile of sand is soft; wine has a strengthening effect when consumed in moderation, but an excessive amount weakens the body. Therefore, one is unable to make any absolute assertions concerning the nature of external existing objects. ${ }^{29}$

The eighth trope summarizes the previous arguments and refers in generalizing terms to the relativity of all that is given:

The Eighth Mode is that based on relativity; and by it we conclude that, since all things are relative, we shall suspend judgement as to what things are absolutely and really existent. [...] "[A]ll things appear relative" [...] with respect to the thing which judges, [...] and with respect to the concomitant percepts [...]. Do things which exist "differentially" differ from relative things or not? If they do not differ, then they too are relative; but if they differ, then, since everything which differs is relative to something (for it has its name from its relation to that from which it differs), things which exist differentially are relative. [...] [A]ll things are relative[.] ${ }^{30}$

In the ninth trope, it is argued that phenomena are perceived differently depending on their constant or rare occurrence. The sea makes a completely different impression on someone seeing it for the first time as opposed to someone

27 Sextus Empiricus, Pyrr. Hyp. I, 118-123, quote I, 121 (S. E., Outlines, pp. 68/69-74/75, quote p. 70/71).

28 Sextus Empiricus, Pyrr. Hyp. I, 124-128, quote I, 125 (S. E., Outlines, pp. 72/73-76/77, quote p. 74/75).

29 Sextus Empiricus, Pyrr. Hyp. I, 129-134 (S. E., Outlines, pp. 76/77-78/79).

30 Sextus Empiricus, Pyrr. Hyp. I, 135-140 (S. E., Outlines, pp. 78/79-82/83). 
used to its sight. Although the sun is much more impressive than a comet, we are more awestruck by a comet because it is a rare event compared to the sun, which is visible every day. Consequently, no definite statement could be made about the nature of the objects themselves. ${ }^{31}$

The tenth and last trope differs from the preceding ones, inasmuch as its argument is not directed towards the reliability of sensory perception, but rather to ethics, maintaining that in light of the variety of ways of life, customs, laws, mythical beliefs, and dogmatic assumptions of men, it is only possible to make a statement about a particular phenomenon, but not on the nature of things. Therefore, here, too, one could only suspend value judgement. ${ }^{32}$

The five Agrippean modes (or tropes) of skeptical epoché (غ่лoxท́) that follow the list above are understood as a supplement that strengthens the argument for isosthenia. These are the modes of dispute or discrepancy ( $\delta \alpha \varphi \omega v i \alpha)$, of infinite regress, of relativity, of hypothesis, and of diallelus or circular reasoning. The first trope bases suspension of judgement on the fact that when various opinions exist on a particular matter the result is an undecidable conflict, an insoluble diaphonia. ${ }^{33}$ The trope on regress ad infinitum says that an argument given as proof of a statement itself requires proof, and this again requires a further proof; this series of confirmations can continue endlessly, so that there is no starting-point for establishing an argument. ${ }^{34}$ The mode deriving from relativity corresponds to the eighth trope in Aenesidemus' list of the ten tropes of suspension of judgement. ${ }^{35}$ The trope of hypothesis relates to the regress ad infinitum. It inevitably occurs when

31 Sextus Empiricus, Pyrr. Hyp. I, 141-144 (S. E., Outlines, pp. 82/83-84/85).

32 Sextus Empiricus, Pyrr. Hyp. I, 145-163 (S. E., Outlines, pp. 84/85-92/93). The isosthenias set up here consist, on the one hand, in the contrasts within the mentioned categories, that is to say, for instance, with regard to habits it was customary for some Ethiopians to tattoo their newborns, but not in other cultures; with regard to the way of life that of the Spartans could be opposed to that of the Italian Greeks, etc.; on the other hand, there is a relativizing contrast between them: for example, custom and legendary belief contradicted one another, when the myths would tell that Kronos had eaten his own children, while it was now customary to take care of children, etc.

33 Sextus Empiricus, Pyrr. Hyp. I, 165 ("That based on discrepancy leads us to find that with regard to the object presented there has arisen both amongst ordinary people and amongst the philosophers an interminable conflict because of which we are unable either to choose a thing or reject it, and so fall back on suspension [of judgement]" [S. E., Outlines, p. 94/95]).

34 Sextus Empiricus, Pyrr. Hyp. I, 166 ("The Mode based upon regress ad infinitum is that whereby we assert that the thing adduced as a proof of the matter proposed needs a further proof, and this again another, and so on ad infinitum, so that the consequence is suspension [of judgement], as we possess no starting-point for our argument” [S. E., Outlines, p. 94/95]).

35 Sextus Empiricus, Pyrr. Hyp. I, 167 ("The Mode based upon relativity, as we have already said, is that whereby the object has such or such an appearance in relation to the subject 
the infinite regression is interrupted by a dogmatic positing, which is then used as proof in the argument that follows, despite clearly not having been proven. ${ }^{36}$ The mode of diallelus occurs when the justification of a statement itself requires the confirmation of this unproven statement. ${ }^{37}$

After naming the five tropes, Sextus gives a demonstration of their application, showing that every object, being either of the senses or of thought, can be referred to these tropes, and he explains the following ${ }^{38}$ : the first trope argues that every object was subject to controversy, since some hold that only objects of perception were true, others that only intelligible objects were true, and still others that some sense-objects and some thought-objects were true. This controversy cannot be resolved. The second trope posits that if the truth of an object of the senses was proven by an object of the senses, this would itself require proof, and so on ad infinitum; and if an object of the senses were to be proven by an object of thought, which are also subject to dispute, this too would lead to an infinite regression. If the proof for an object of thought is sought from an object of the senses, then "[...] since an intelligible was adduced to establish the sensible and a sensible to establish the intelligible, the Mode of circular reasoning is brought in." ${ }^{39}$ Thus, the fifth trope applies. If, in order to escape this conclusion, some postulate without proof was assumed, the inescapable mode of hypothesis (this also harks back to the fourth trope) would be brought in for the opposite or even the subject of inquiry itself could just as well be hypothesized. Finally, which illustrates the third trope, all objects of perception are shown to be relative, since they were relative to those who have the sensations.

In summary, according to the argument of this passage, every perceptible object and/or its qualification can easily be referred to one of the five tropes. Malte Hossenfelder notes that what followed from the demonstrated application

judging and to the concomitant percepts, but as to its real nature we suspend judgement" [S. E., Outlines, p. 94/95]).

36 Sextus Empiricus, Pyrr. Hyp. I, 168 ("We have the Mode based on hypothesis when the Dogmatists, being forced to recede ad infinitum, take as their starting-point something which they do not establish by argument but claim to assume as granted simply and without demonstration" [S. E., Outlines, p. 94/95]).

37 Sextus Empiricus, Pyrr. Hyp. I, 169 ("The Mode of circular reasoning is the form used when the proof itself which ought to establish the matter of inquiry requires confirmation derived from that matter; in this case, being unable to assume either in order to establish the other, we suspend judgement about both” [S. E., Outlines, p. 94/95]). Jonathan Barnes, The Toils of Scepticism, Cambridge/New York 1990, provides a detailed study of the Agrippean tropes in Sextus' Outlines.

38 Sextus Empiricus, Pyrr. Hyp. I, 169-177 (S. E., Outlines, pp. 94/95-100/101).

39 Sextus Empiricus, Pyrr. Hyp. I, 172 (S. E., Outlines, p. 96/97). 
was 'that the five tropes come into effect in a different order and only in connection with each other, so that they basically constitute one single complex trope' ("[...] daß [die fünf Tropen] in einer anderen Reihenfolge und nur im Zusammenhang wirksam sind, so daß sie im Grunde einen einzigen komplexen Tropus ausmachen"). ${ }^{40}$ Sextus then goes on to discuss the parallel application, in which an object of thought has to be decided and concludes:

[...] objects of thought, or intelligibles, are relative; for they are so named on account of their relation to the person thinking, and if they had really possessed the nature they are said to possess, there would have been no controversy about them. [...] [T]he intelligible also is referred to the Five Modes, so that in all cases we are compelled to suspend judgement concerning the object presented. ${ }^{41}$

Whereas the initial ten tropes illustrated the relativity of sensory perception, the above demonstrates that the same difficulty applies to thought objects as well. The result is that, from a skeptical point of view, no reliable knowledge is possible - everything is relative.

Finally, Sextus mentions two further modes of suspension of judgement handed down by the later skeptics. These were thought to introduce aporia about everything by showing that, since everything was apprehended either through itself or by means of something else, nothing can be apprehended either by means of itself or through another thing. That nothing can be apprehended by means of itself is clear from the controversy that existed regarding all things. The addition here is that nothing can be apprehended by means of something else, in other words the means by which an object was apprehended must itself always be apprehended by means of something else, so that one is either thrown into a process of regress ad infinitum or of diallelus. ${ }^{42}$

After presenting the modes of suspension of judgement, Sextus gives a systematic account of the programmatic $\varphi \omega v \alpha$ i of the skeptics, the 'skeptical phrases.' These are succinct formulations that mark a skeptical position. He emphasizes that these expressions are not to be understood as absolute, for even to them no pure significance can be ascribed, they are only relative to the

40 Hossenfelder, Stoa, Epikureismus und Skepsis (cf. note 5), pp. 158 f., here p. 158 (see also the explanatory notes in his "Einleitung" [cf. note 9], pp. 44 f.).

41 Sextus Empiricus, Pyrr. Hyp. I, 177 (S. E., Outlines [cf. note 6], p. 100/101).

42 Sextus Empiricus, Pyrr. Hyp. I, 178 f. (S. E., Outlines, pp. 100/101-102/103). Between the exposition of these two tropes and the presentation of the 'skeptical expressions,' a further list of tropes is given, which, however, are not classified into the tropes of suspension: it is a list of eight arguments by Aesidemus that oppose the concept of causation (I, 180-186). For this, see Hossenfelder, "Einleitung” (cf. note 9), p. 44, n. 76. 
skeptics uttering them; they too must be met with indifference. Furthermore, "[...] we do not employ them universally about all things, but about those which are non-evident and are objects of dogmatic inquiry; and that we state what appears to us and do not make any positive declarations as to the real nature of external objects [...]." ${ }^{43}$ Pyrrhonian skepticism is relative and its epistemological effectiveness consists in the rejection of any claim to truth in the field of knowledge by showing diaphonias and their un-decidability. The telos of the 'skeptical phrases,' as well as that of the 'tropes of suspension of judgement,' is isosthenia.

The first expression, 'Not more' (oủ $\mu \tilde{\alpha} \lambda \lambda o v$ ), stands elliptically for 'Not this more than that, up than down.' This expression makes clear that it is the expression of a subjective opinion that, in the face of the equipollent conflict of several opinions, will perforce withdraw from taking up a position. ${ }^{44}$ Next, Sextus com-

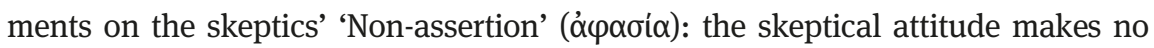
assertions, either affirmative or negative. ${ }^{45}$ Further expressions cited by Sextus are

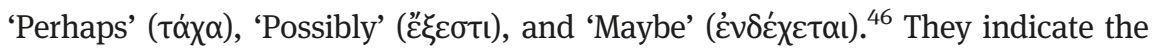
'inability to make assertions' and show the Pyrrhonian attitude of epoché, made

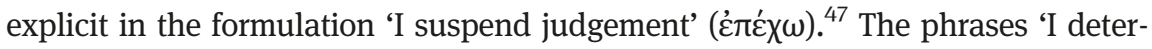

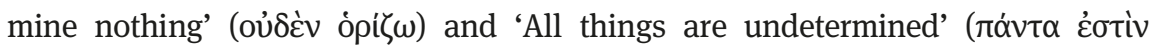

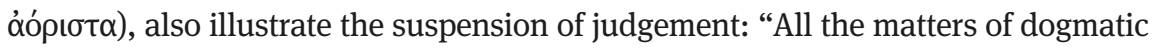
inquiry which I have examined appear to me to be such that no one of them is preferable to the one in conflict with it in respect of credibility or incredibility."48

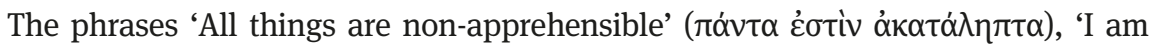

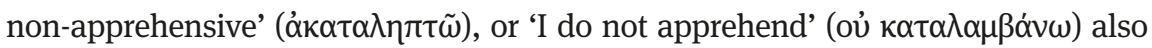
express epoché, emphasize the subjective-relative aspect, and testify to the indifference with which the skeptic is to act even towards the expressions

43 Sextus Empiricus, Pyrr. Hyp. I, 206 ff., quote I, 208 (S. E., Outlines [cf. note 6], p. 122/123). 44 Sextus Empiricus, Pyrr. Hyp. I, 188-191, quote I, 188 (S. E., Outlines, pp. 108/109-110/111, quote p. 108/109).

45 Sextus Empiricus, Pyrr. Hyp. I, $192 \mathrm{f}$. ("Non-assertion, then, is avoidance of assertion in the general sense in which it is said to include both affirmation and negation, so that nonassertion is a mental condition of ours because of which we refuse either to affirm or to deny anything. [.. .] It must also be borne in mind that what, as we say, we neither posit nor deny, is some one of the dogmatic statements made about what is non-apparent; for we yield to those things which move us emotionally and drive us compulsorily to assent” [S. E., Outlines, pp. 110/111-112/113]).

46 Sextus Empiricus, Pyrr. Hyp. I, 194 f. (S. E., Outlines, pp. 112/113-114/115).

47 Sextus Empiricus, Pyrr. Hyp. I, 196 (S. E., Outlines, p. 114/115).

48 Sextus Empiricus, Pyrr. Hyp. I, 197 f., quote I, 198 (S. E., Outlines, pp. 114/115-116/117, quote p. 116/117). 
themselves. ${ }^{49}$ Finally, the skeptical strategy of isosthenia itself is formulated as

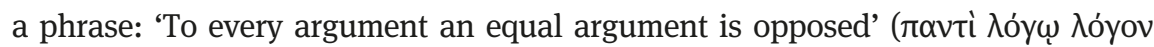

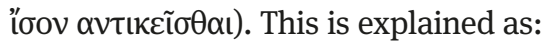

So whenever I say [this] [...], what I am virtually saying is "To every argument investigated by me which establishes a point dogmatically, it seems to me there is opposed another argument, establishing a point dogmatically, which is equal to the first in respect of credibility and incredibility" [......$^{50}$

At the end of the first book of the Hypotyposes, Sextus differentiates Pyrrhonian skepticism from other schools of philosophy, particularly "Academic philosophy." 51 This is the second tradition of Greek skepticism known as Academic skepticism that is based on the Socratic dictum 'I know that I know nothing.' It was promulgated by Plato's Academy, and as the 'New Academy' under the direction of Arcesilaus of Pitane (c. 315-241 BCE) and Carneades of Cyrene (c. 213-129 BCE), and his pupil Cleitomachus of Carthago (c. 186-109 BCE), as well as the slightly later Philo of Larissa (c. 159-84 BCE). ${ }^{52}$ Unlike Pyrrhonism, no unified account of the Academic variant of skepticism has survived. What we do know is mainly based on the writings of M. Tullius Cicero (106-43 BCE), especially Academica, Diogenes Laertius' (3rd century CE) Vitae et sententiae philosophorum, and Aurelius Augustinus' (354-430) discussion Contra Academicos. Its impact extends into the Early Modern era. In this period, however, the terms 'skeptical' and 'Pyrrhonian' were used synonymously by most contemporaries, whereas the adherents of Academic skepticism were, in accordance with Sextus Empiricus' view, not considered skeptics, but rather 'negative dogmatists. ${ }^{, 53}$ Sextus states:

49 Sextus Empiricus, Pyrr. Hyp. I, 200 f. (S. E., Outlines, pp. 116/117-118/119). Cf.: “'All the non-apparent matters of dogmatic inquiry which I have investigated appear to me nonapprehensible.' And this is the utterance not of one who is positively asserting [...], but of one who is announcing his own state of mind, 'wherein', he says, 'I conceive that up till now I myself have apprehended nothing owing to the equipollence of the opposites [...]”” (I, 200 [p. 118/119]).

50 Sextus Empiricus, Pyrr. Hyp. I, 202-205, quote I, 203 (S. E., Outlines, pp. 118/119-120/121, quote p. 120/121).

51 Sextus Empiricus, Pyrr. Hyp. I, 220-235 (S. E., Outlines, pp. 132/133-144/145). Furthermore, the relevant differences to "Heracleitean philosophy" (I, $210 \mathrm{ff}$.), "Democritean philosophy" (I, 213 f.), "Cyrenaic doctrine” (I, 215) and "Protagorean doctrine” (I, 216-219) are pointed out. 52 Cf. Hossenfelder, Stoa, Epikureismus und Skepsis (cf. note 5), pp. 191-200, here pp. $191 \mathrm{f}$.

53 For the latter, see Popkin, The History of Scepticism (cf. note 1), p. XX; for the aspect of the outlined transmission, see Popkin, The History of Scepticism, pp. XVII f.; Olejniczak Lobsien, Skeptische Phantasie (cf. note 2), pp. 36 f.; for the reception history, see in detail: Charles B. Schmitt, Cicero Scepticus: A Study of the Influence of the Academica in the Renaissance, The Hague 1972. 
The adherents of the New Academy, although they affirm that all things are nonapprehensible, yet differ from the Sceptics even, as seems probable, in respect of this very statement that all things are non-apprehensible (for they affirm this positively, whereas the Sceptic regards it as possible that some things may be apprehended) $\left[\ldots . . .^{54}\right.$

The significant distinction between these two classical forms of skepticism is that the skepticism of the Academics is universal and absolute, the recognizability of truth is considered impossible in principle. The skepticism of the Pyrrhonians, however, is universal and relative. Sextus Empiricus notes the consequences of this difference:

[...] [T] hey [the Academics] differ from us quite plainly in their judgement of things good and evil. For the Academicians do not describe a thing as good or evil in the way we do; for they do so with the conviction that it is more probable that what they call good is really good rather than the opposite, and so too in the case of evil, whereas when we describe a thing as good or evil we do not add it as our opinion that what we assert is probable, but simply conform to life undogmatically that we may not be precluded from activity. And as regards sense-impressions, we say that they are equal in respect of probability and improbability, so far as their essence is concerned, whereas they assert that some impressions are probable, others improbable. And respecting the probable impressions they make distinctions: some they regard as just simply probable, others as probable and tested, others as probable, tested, and 'irreversible.' [. . . Furthermore, as regards the End (or aim of life) we differ from the New Academy; for whereas the men who profess to conform to its doctrine use probability as the guide of life, we live in an undogmatic way by following the laws, customs, and natural affections. ${ }^{55}$

Academic skepticism's rejection of truth and certainty as a matter of principle, as well as its concomitant assumption that even deception cannot in principle be excluded, led to its substitution of the certainty criterion with the criterion of

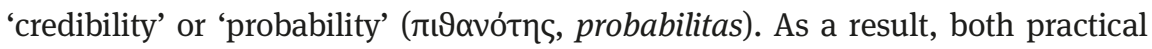
action and judgment about the world are oriented according to probabilities. Ideas are distinguished by degrees of credibility and a detailed examination of the respective object allows, to a certain extent, a provisional 'understanding' of reality, but only when the verified is credible or likely as opposed to true rather than false. This modification developed by Academic skepticism has constructive potential in terms of scientific conceptualizations.

Furthermore, the passage quoted above illuminates an aspect of the debate over skepticism that has been present from the beginning, namely, praxis, i.e.,

54 Sextus Empiricus, Pyrr. Hyp. I, 226 (S. E., Outlines, p. 138/139).

55 Sextus Empiricus, Pyrr. Hyp. I, 226-231 (S. E., Outlines, pp. 138/139-142/143). For the differences between the two forms of skepticism, see Hossenfelder, "Einleitung" (cf. note 9), pp. 12-30. 
the skeptical attitude's compatibility with real (practical) life. Given the skeptics' radical and all-encompassing indifference based on the un-decidability of the equally balanced conflict of opinions, philosophical skepticism has always been prey to the accusation of apraxia. To this the Pyrrhonians respond by saying: 'we [...] simply conform to life undogmatically that we may not be precluded from activity' and 'we live in an undogmatic way by following the laws, customs, and natural affections.' Before explaining further, however, it is important to take note of the following foundational passage on the aspect of the "criterion" of skepticism:

The criterion, then, of the Sceptic School is, we say, the appearance, giving this name to what is virtually the sense-presentation. For since this lies in feeling and involuntary affection, it is not open to question. Consequently, no one, I suppose, disputes that the underlying object has this or that appearance; the point in dispute is whether the object is in reality such as it appears to be. Adhering, then, to appearances we live in accordance with the normal rules of life, undogmatically, seeing that we cannot remain wholly inactive. ${ }^{56}$

The decisions that govern practical life - for Pyrrhonian skepticism recognizes 'phenomena' - comply with everyday life experience and the accepted customs

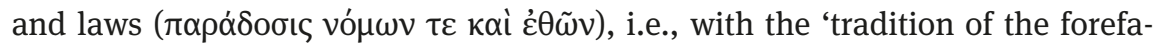
thers. ${ }^{57}$ In this sense, the skeptic does not make his 'own' decisions, which in turn would have to be based on value judgments (epoché also relates to the realm of moral values), but bases his actions on what is already accepted, usual, and customary in the society in which he happens to live. He adheres to the given law, follows traditional habits and customs, adopts in a way decisions that others have made, and thus lives a life guided by serenity. In this sense, non-action in daily life implies assuming a particular stance or position, whereas living according to the cultural morals and rules of one's society

56 Sextus Empiricus, Pyrr. Hyp. I, 22 (S. E., Outlines [cf. note 6], p. 16/17; my italics). Sextus then explains the different spheres of everyday life as follows: "And it would seem that this regulation of life is fourfold, and that one part of it lies in the guidance of Nature, another in the constraint of the passions, another in the tradition of laws and customs, another in the instruction of the arts. Nature's guidance is that by which we are naturally capable of sensation and thought; constraint of the passions is that whereby hunger drives us to food and thirst to drink; tradition of customs and laws, that whereby we regard piety in the conduct of life as good, but impiety as evil; instruction of the arts, that whereby we are not inactive in such arts as we adopt. But we make all these statements undogmatically" (I, $23 \mathrm{f.}$ [p. 16/17]).

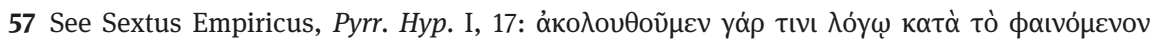

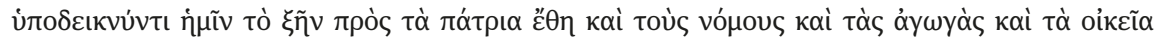
$\pi \alpha \dot{\theta} \theta$ /“For we follow a line of reasoning which, in accordance with appearances, points us to a life conformable to the customs of our country and its laws and institutions, and to our own instinctive feelings" (S. E., Outlines, p. 12/13). 
implies a non-stance. The problematic implications of consistent skepticism and the response of the skeptics appear in condensed form in an account by Diogenes Laertius on the conflict between dogmatists and skeptics.

And when the dogmatists argue that he [the skeptic] may thus live in such a frame of mind that he would not shrink from killing and eating his own father if ordered to do so, the Sceptic replies that he will be able so to live as to suspend his judgement in cases where it is a question of arriving at the truth, but not in matters of life and the taking of precautions. Accordingly we may choose a thing or shrink from a thing by habit and may observe rules and customs. ${ }^{58}$

\subsection{Skepticism in the Early Modern Period}

Ancient skepticism was rediscovered in the Early Modern period. Henri Estienne's first printing of a Latin translation of the Outlines of Pyrrhonism in 1562, followed, in 1569, by Gentian Hervet's Latin translation of Sextus Empiricus' complete works, resulted in widespread dissemination of Pyrrhonism's most important source. Sextus' writings propelled the renaissance of skepticism in the 16th and 17th centuries, and this in turn had a profound impact on the development of Western culture from this period on. The Greek original was published in 1621. The first vernacular translations of the Hypotyposeis, dating to 1590-1591, include a partial translation into English, and a full English version was printed in 1659. ${ }^{59}$ This is not to say that Sextus' writings were previously unknown. The Italian humanist intellectuals of the 15th century, for example, were clearly familiar with the work..$^{60}$ Moreover, Gianfrancesco Pico della Mirandola's Examen vanitatis doctrinae gentium (published in 1520), is clearly in dialogue with the Outlines of Pyrrhonism, a text he had to have encountered in manuscript form. ${ }^{61}$ The writings of Diogenes Laertius, Cicero, Lucian, and Galen, also served as sources of information on skeptical thinking, especially in the first half of the 16th century. ${ }^{62}$ Richard Popkin writes: "From the mid-fifteenth century onward, with the discovery of manuscripts

58 Diogenes Laertius, Vitae philosophorum IX,108 (Lives of Eminent Philosophers [cf. note. 4], p. 200/201).

59 See Popkin, The History of Scepticism (cf. note 1), pp. $18 \mathrm{f}$.

60 See, for instance, Luciano Floridi, Sextus Empiricus: The Transmission and Recovery of Pyrrhonism, Oxford/New York 2002, pp. 13-25, regarding the transmission in the Middle Ages; also pp. 25-51, regarding the reception in the Renaissance, and esp. pp. 27-35, regarding the rediscovery by the Italian humanists.

61 See Popkin, The History of Scepticism (cf. note 1), pp. 19-27.

62 See pp. 28-38. 
of Sextus' writings, there is a revival of interest and concern with ancient skepticism and with the application of its views to the problems of the day."63

It is without question that there had been discourses informed by skeptical thinking, or bearing an affinity to skepticism before the Early Modern period. ${ }^{64}$ Late medieval debates about nominalism, for example, particularly concepts going back to William of Ockham (1285-1349), foreshadow central (skeptical) foundations of modernity. Foundations that only begin to develop in the 16th century, or rather are re-appropriated within the context of this period. ${ }^{65}$ It is precisely this aspect, the 'context,' that needs to be emphasized in order to clarify the specificity of the Early Modern period's reception of skepticism as an integral part of modernity. Nominalism and Ockhamism were ultimately part of an intrasystem conflict, that is, situated in an internal conflict within the system of Christian theology, specifically, scholasticism.

The invention of letterpress printing enabled the rapid and broad dissemination of the skeptics' ideas in the Early Modern period. It was a period characterized by massive uncertainty caused by an onslaught of changes that weakened or profoundly shook the traditional view of the world. Renaissance humanism, the Reformation, and the increasing emancipation of the natural sciences are constitutive elements of this historical context. However, the central event that shook all previous certainties to their core was the discovery of the New World. The Age of Discovery, beginning in the early 15th century, led to profound political, economic, scientific, and cultural transformations, and confronted Europeans with a reality unknown in the theological tradition or ancient texts - a fact that must have been shocking. With these discoveries the Aristotelian system began to

63 P. XX.

64 See, for instance, the study by Dominik Perler, Zweifel und Gewißheit: Skeptische Debatten im Mittelalter, Frankfurt am Main 2006.

65 See, e.g., Floridi's remarks: "The late medieval debate on protoskeptical issues was connected [...] with epistemological investigations resulting from factors such as a critical approach to Aristotle's texts, the spread of logical studies and the parallel debate upon the paradoxes and 'insolubilia', the coming to maturity of the controversy over the nature of universals, and the discussion concerning the implications of the doctrine of the total contingency of the world. Ockhamism, for example, by developing to its final consequences the presupposition of God's boundless omnipotence, could raise a number of doubts about the nature of reality and the power of reason that would find a conceptual echo in Descartes's Meditationes. If God was really omnipotent, nothing was necessarily as it was; everything could have been otherwise. The possibility that things may in fact differ completely from the way they appear could be seriously and consistently entertained" (Floridi, Sextus Empiricus [cf. note 60], pp. 23 f.). On the role of Ockhamism in the constitution of the modern era, see Hans Blumenberg, The Legitimacy of the Modern Age, trans. Robert M. Wallace, Cambridge, MA/ London 1999, pp. 145-203 (esp. pp. 160-163 [on the Paris Decree of Bishop Tempier of 1277]). 
unravel. The existence of previously unknown continents, the circumnavigation of the globe, and the cosmological discoveries of Copernicus, and later of Galileo and Kepler, contradicted the Aristotelian epistemology that had, in principle, given reliability to sensory perception. The idea that the earth is a sphere and not a disk, that it orbits the sun and not vice versa, radically contradicts perception. These advances in knowledge, together with the uncertainty they engendered, proved fertile ground for the growth of skepticism.

The challenges to Aristotelian authority were not limited to the field of epistemology, but were extended to theology as well. The Thomist tradition of scholasticism (developed by Thomas Aquinas [1225-1274]) was based on Aristotle and the Aristotelian epistemological position that knowledge starts from perception and that the senses, if they are governed by reason, are able to transmit 'truth' about the world within the scope of the human possibilities of knowledge. Thomism retained its hold on theology, particularly in 16th and 17th century Spain. The Counter-Reformation, in particular the Council of Trent (1545-1563) reaffirmed and based itself on Thomist ideals. While this 'Aristotelized' current of Christianity collides with skepticism and its challenge to the reliability of sensory perception, the Paulinian-Augustinian tradition, the second main current in Christian discourse expressed in Nominalism, Erasmism, and Protestantism, has several affinities to skepticism ${ }^{66}$ and thus ultimately echoes the Christian system's inherent 'mistrust' of everything sense-related.

The Reformation is one context in which philosophical skepticism reemerged in the Early Modern period. Firstly, the Reformers' questioning of the ecclesiastical authority's claim to absoluteness as the mediator of a 'true faith' already bears skeptical traits. Yet, the prevalence of skepticism in the theological discourses of the 16th and 17th centuries went far beyond this. Accusations of skepticism were used by both ideological camps to disavow their enemies. It became a standard claim against the Reformation by representatives of the Counter-Reformation, but it was also used by Martin Luther (1483-1546) in De servo arbitrio [On the Bondage of the Will] (1525), his response to Erasmus of

66 The knowledge of the world, which we can obtain through sense perception, is always a vague impression: See, e.g., 1 Cor 13, 9-12 ("Ex parte enim cognoscimus, et ex parte prophetamus. Cum autem venerit quod perfectum est, evacuabitur quod ex parte est. [...] Videmus nunc per speculum in ænigmate: tunc autem facie ad faciem. Nunc cognosco ex parte: tunc autem cognoscam sicut et cognitus sum.”/‘For we know in part, and we prophesy in part. But when that which is perfect is come, then that which is in part shall be done away. [...] For now we see through a glass, darkly; but then face to face: now I know in part; but then shall I know even as also I am known' [my italics]). All biblical quotations in English are from the King James Version; those in Latin are from the Vulgata. 
Rotterdam's (1469-1536) polemic against Protestantism De libero arbitrio [On Free Will] (1524). Skepticism also served both sides as an instrument of argumentation to strengthen each one's position. The controversy over the regula fidei already implies the classic skeptical problem of the 'criterion of truth.' The argument put forward by Erasmus in De libero arbitrio, or the attitude he ultimately adopts corresponds to Pyrrhonism, ${ }^{67}$ namely that it is not possible to state what is the 'true' truth, as Protestantism does with regard to Scripture. Given that nothing can be known with certainty, said Erasmus, it is therefore better to suspend judgment, rely on tradition, and stick to the guidelines of the Church. Primarily on the basis of this 'conservative-Pyrrhonian attitude,' which regarded tradition and custom as the most appropriate guide for practical life in view of uncertainty, there was, in the 16th century, significant ideological consistency between the 'new skeptics,' the nouveaux Pyrrhoniens following Montaigne, as Popkin calls them, and those who advocated for the preservation of traditional Christianity. These Counter-Reformers were soon to abandon this position, however, over the course of the 17th century, in favor of a decidedly anti-skeptical position, as they instead began to insist, frantically, on dogmatic certainty and moral theological principles. ${ }^{68}$

The undisputedly most influential figure in the mediation of ancient skeptical thinking and the formulation of Early Modern skepticism was Michel de Montaigne (1533-1592). In his History of Scepticism, Popkin refers to Montaigne, the author of the Essais (1580/88/95) as "[...] the thinker who most absorbed the new influence of Sextus Empiricus and who used this material on the intellectual problems of his time [...]," saying further that: "His Pyrrhonism helped to create la crise pyrrhonienne of the early seventeenth century. [...] [T]hrough Montaigne, Renaissance skepticism became crucial in the formation of modern philosophy [...].”69

Given this pivotal role in the development of skepticism in the Early Modern period, the following section consists of an in-depth discussion on

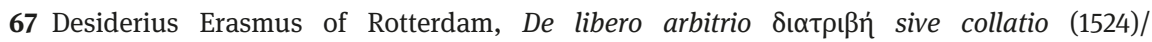
A Discussion of Free Will, trans. Peter Macardle, in: [Erasmus of Rotterdam], Collected Works of Erasmus, ed. William Barker, Alexander Dalzell, et al., vol. 76: Controversies, ed. Charles Trinkaus, Peter Macardle, and Clarence H. Miller, Toronto/Buffalo/London 1999, pp. 1-89, see esp. Ia 4 ff. (pp. 7 f.).

68 See Popkin, The History of Scepticism (cf. note 1), pp. 3-16 (among other things, on the controversy between Luther and Erasmus), pp. 57-79 (on the alliance between nouveaux pyrrhonisme and orthodox Christian theology), pp. 80-110 (on the growing distancing of the Pyrrhonians in the 17th century and the anti-skepticist reaction [cf. in this respect also the subchapter on Descartes' engagement with skepticism, chap. 1.2.3]).

69 P. 43. 
Montaigne's Essais. It is followed by a discussion of the equally influential Quod nihil scitur (1581) by Francisco Sánchez (1551-1623). The final section of the chapter explores René Descartes (1596-1650) and his highly influential work to 'overcome of the skeptical crisis.'

\subsubsection{Michel de Montaigne}

"Il n'y a raison qui n'en aye une contraire, dit le plus sage party des philosophes" ['No reason but has its contrary,' says the wisest of the Schools of Philosophy] is the opening line of the 15th chapter of the second book (titled Que nostre desir s'accroist par la malaisance [That difficulty increases desire]) of Michel de Montaigne's Essais, first published in Bordeaux in 1580. This expression of the Pyrrhonian-skeptical concept of isosthenia is one of the text's many explicit references to ancient skepticism (which Montaigne calls here even the 'wisest party of philosophers'). ${ }^{70}$ Montaigne's reading of Sextus is particularly apparent in his famous essay Apologie de Raimond de Sebonde [Apology for Raymond Sebond] (II, 12). In the course of this extensive and complex text, whose starting point is a defense of Raimundus Sabundus' Theologia naturalis (1434-1436), but whose further course develops towards a contrary position, central elements of Pyrrhonism are presented, complete with extensive quotations from the Outlines. The following passage is one in which Montaigne discusses the unreliability of sensory perception by referring back to Sextus' tropes:

Les sens sont aux uns plus obscurs et plus sombres, aux autres plus ouverts et plus aigus. Nous recevons les choses autres et autres, selon que nous sommes et qu'il nous semble. Or nostre sembler estant si incertain et controversé, ce n'est plus miracle, si on nous dit, que nous pouvons avouer que la neige nous apparoist blanche, mais que d'establir si de son essence elle est telle, et à la verité, nous ne nous en sçaurions respondre: et, ce commencement esbranlé, toute la science du monde s'en va necessairement à vau-l'eau. Quoy, que noz sens mesmes s'entr'empeschent l'un l'autre? une peinture semble eslevée à la veue, au

70 Michel de Montaigne, II, 15: Que nostre desir s'accroist par la malaisance, in: Montaigne, Les Essais, ed. Jean Balsamo, Michel Magnien, and Catherine Magnien-Simonin ("Notes de lecture" and "Sentences peintes" ed. by Alain Legros), Paris 2007, pp. 649-655, here p. 649. The English translation is to the edition: Michel de Montaigne, The Complete Essays, trans. and ed. Michael Andrew Screech, London 1991 (II, 15: That difficulty increases desire, pp. 694-700, here p. 694). It is worth mentioning that the skeptical principle of isosthenia, ПАNTI $\Lambda$ ОГ $\Omega \Lambda \mathrm{O} Г \Sigma$ I $\Sigma O \Sigma$ ANTIKEITAI, along with other guiding principles of Pyrrhonian skepticism, quoted from Sextus' Hypotyposeis, also belongs to those sayings and maxims which are burnt into the beams of the famous library in the 'Tour de Montaigne' (cf. "Sentences peintes et autres inscriptions de la bibliothèque de Montaigne,” in: Montaigne, Les Essais, pp. 1309-1316, here p. 1314 [No. 35]). 
maniement elle semble plate[;] [...] le miel est plaisant au goust, mal plaisant à la veue. [.. .] Or, nostre estat accommodant les choses à soy, et les transformant selon soy, nous ne sçavons plus quelles sont les choses en verité, car rien ne vient à nous que falsifié et alteré par nos sens. Où le compas, l'esquarre et la regle sont gauches, toutes les proportions qui s'en tirent, tous les bastimens qui se dressent à leur mesure, sont aussi necessairement manques et defaillans. L'incertitude de noz sens rend incertain tout ce qu'ils produisent. ${ }^{71}$

'Some people's senses are dullish and dimmer: others are more open and acute. We perceive objects to be like this or that in accordance with our own state and how they seem to us. But seeming, for human beings, is so uncertain and so controvertible that is it no miracle if we are told that we may acknowledge that snow seems white to us but cannot guarantee to establish that it is truly so in essence. And once you shake that first principle, all the knowledge in the world in inevitably swept away. What about our very sense hampering each other? A painting may seem to have depth, but feels flat [...] [;] honey is pleasent to taste, unpleasant to look at [. . . Now, since our state makes things correspond to itself and transforms them in conformity with itself, we can no longer claim to know what anything truly is: nothing reaches us except as altered and falsified by our senses. When the compass, the set-square and the ruler are askew, all the calculations made with them and all the structures raised according to their measurements, are necessarily out of true and ready to collapse. The unreliability of our senses renders unreliable everything which they put forward. ${ }^{72}$

71 Montaigne, II, 12: Apologie de Raimond de Sebonde, in: Montaigne, Les Essais (cf. note 70), pp. 458-642, here pp. 636 f.; on the explicit reference to skepticism, see esp. pp. 529-535 (there, e.g., on epoché, ataraxy, the 'skeptical expressions,' and the aspect of praxis: 'Or cette assiette de leur [des Pyrrhoniens] jugement droicte, et inflexible, recevant tous objects sans application et consentement, les achemine à leur Ataraxie; qui est une condition de vie paisible, rassise, exempte des agitations que nous recevons par l'impression de l'opinion et science

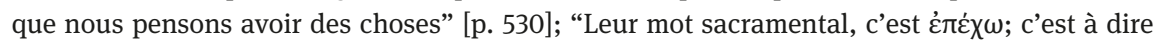
je soutiens, je ne bouge. [...] Leur effect [de leurs refreins], c'est une pure, entiere, et tresparfaicte surceance et suspension de jugement. Ils se servent de leur raison, pour enquerir et pour debattre: mais non pas pour arrester et choisir. Quiconque imaginera une perpetuelle confession d'ignorance, un jugement sans pente et sans inclination, à quelque occasion que ce puisse estre, il conçoit le Pyrronisme” [p. 532]; "Quant aux actions de la vie, ils sont en cela de la commune façon. Ils se prestent et accommodent aux inclinations naturelles, à l'impulsion et contrainte des passions, aux constitutions des loix et des coustumes, et à la tradition des arts[.] [. . . ] Ils laissent guider à ces choses là leurs actions communes, sans aucune opination ou jugement” [pp. 532 f.]), pp. 555 ff. (there also the much cited "Que sçay-je?” [What do I know?]: “Quand ils [les philosophes Pyrrhoniens] prononcent: J'ignore, ou, Je doubte, ils disent que cette proposition s'emporte elle mesme, quant et quant le reste: ny plus ne moins que la rubarbe, qui pousse hors les mauvaises humeurs, et s'emporte hors quant et quant elle mesmes. Cette fantasie est plus seurement conceue par interrogation: Que sçay-je? comme je la porte à la devise d'une balance" [p. 555]), pp. 613-618, pp. 625 f. and pp. 633-639.

72 Montaigne, II, 12: An Apology for Raymond Sebond, in: Montaigne, Essays (cf. note 70), pp. 489-682, here pp. $676 \mathrm{ff}$. 
Later, after elaborating on the problem of the criterion of knowledge according to the skeptic tradition, ${ }^{73}$ the narrating I concludes that there was no foundation of certainty, no basis for being able to judge with certainty, and that the attempt to grasp real being was like attempting to hold water in one's hands:

Finalement, il n'y a aucune constante existence, ny de nostre estre, ny de celuy des objects. Et nous, et nostre jugement, et toutes choses mortelles, vont coulant et roulant sans cesse. Ainsin il ne se peut establir rien de certain de l'un à l'autre, et le jugeant et le jugé estans en continuelle mutation et branle. Nous n'avons aucune communication à l'estre, par ce que toute humaine nature est tousjours au milieu entre le naistre et le mourir, ne baillant de soy qu'une obscure apparence et ombre, et une incertaine et debile opinion. Et si, de fortune, vous fichez vostre pensée à vouloir prendre son estre, ce sera ne plus ne moins que qui voudroit empoigner l'eau: car tant plus il serrera et pressera ce qui de sa nature coule par tout, tant plus il perdra ce qu'il vouloit tenir et empoigner. ${ }^{74}$

'To conclude, there is no permanent existence either in our being or in that of objects. We ourselves, our faculty of judgment and all mortal things are flowing and rolling ceaselessly: noting certain can be established about one from the other, since judged and judging are ever shifting and changing. We have no communication with Being; as human nature is whole situated, forever, between birth and death, it shows itself only as a dark shadowy appearance, an unstable weak opinion. And if you should determine to try and grasp what Man's being is, it would be exactly like trying to hold a fistful of water: the

73 I.e. in the sense of the infinite regress, cf.: "Pour juger des apparences que nous recevons des subjets, il nous faudroit un instrument judicatoire: pour verifier cet instrument, il nous y faut de la demonstration: pour verifier la demonstration, un instrument, nous voilà au rouet. Puis que les sens ne peuvent arrester nostre dispute, estans pleins eux-mesmes d'incertitude, il faut que ce soit la raison: aucune raison ne s'establira sans une autre raison, nous voylà à reculons jusques à l'infiny" (Montaigne, Apologie [cf. note 71] p. 638). Our ideas are derived from sensory perception, as the conclusion goes, but this only indicates how things appear to us, not how they really are ("Nostre fantasie ne s'applique pas aux choses estrangeres, ains elle est conceue par l'entremise des sens; et les sens ne comprennent pas le subject estranger, ains seulement leurs propres passions: et par ainsi la fantasie et apparence n'est pas du subject, ains seulement de la passion et souffrance du sens; laquelle passion, et subject, sont choses diverses: parquoy qui juge par les apparences, juge par chose autre que le subject" [p. 638]), so that a reliable judgment on the world becomes impossible, whether by means of direct sense-experience, or by means of ideas ("Tout ainsi comme, qui ne cognoit pas Socrates, voyant son pourtraict, ne peut dire qu'il luy ressemble. Or qui voudroit toutesfois juger par les apparences: si c'est par toutes, il est impossible, car elles s'entr'empeschent par leurs contrarietez et discrepances, comme nous voyons par experience: Sera ce qu'aucunes apparences choisies reglent les autres? Il faudra verifier cette choisie par une autre choisie, la seconde par la tierce: et par ainsi ce ne sera jamais faict” [p. 639]).

74 P. 639. 
more tightly you squeeze, anything the nature of which is always to flow, the more you will lose what you try to retain in your grasp. ${ }^{, 75}$

As this quotation shows, skeptical uncertainty does not relate to the outside world alone, but also to the human being who perceives and judges it. Montaigne's Essais not only convey the concrete contents of the ancient skeptics' concepts in the sense of a humanistic tradition, but, even more importantly, productively transform them. ${ }^{76}$ With his work Montaigne created a new literary form that was to have a profound impact on writing and thinking in the

75 Montaigne, An Apology, p. 680.

76 On the specificity of this 'adaptation'/'transformation' ("An-Verwandlung”) in the Apologie, see, amongst others, Andreas Kablitz, “Montaignes 'Skeptizismus.' Zur Apologie de Raimond Sebond (Essais: II, 12)," in: Gerhard Neumann (ed.), Poststrukturalismus: Herausforderung an die Literaturwissenschaft, Stuttgart 1997, pp. 504-539, quote p. 505; '[the transformation consisted in that] Montaigne's appropriation of this skepticism develops from its techniques an instrument with the help of which he also rejects the premises of Pyrrhonism itself; [...] on the other hand, he brings to light the abyss of that discourse which is bound to a Christian concept of truth' (“[Die Transformation besteht darin, daß] [...] Montaignes Aneignung dieser Skepsis aus ihren Techniken ein Instrument entwickelt, mit dessen Hilfe er ebenso den Prämissen des Pyrrhonismus selbst eine Absage erteilt, [...] er zum anderen die Abgründigkeit jenes Diskurses zum Vorschein bringt, der einem christlichen Wahrheitsbegriff verpflichtet ist" [ibid.]). On Montaigne's 'skeptical writing' in the Essais, the "aestheticproductive transformation of the philosophical reference text," see, furthermore, esp. Zepp, An Early Self (cf. note 1), pp. 93-115 (quote p. 99, on the Apologie: pp. 100 ff.). The scholarly literature on Montaigne's skepticism from a philosphical and philosophico-historical perspective is abundant, as Nicola Panichi notes: "[...] whole generations of scholars have practiced [on Montaigne's scepticism] [...]" ("Montaigne and Plutarch. A Scepticism That Conquers the Mind,” in: Paganini/Maia Neto [eds.], Renaissance Scepticisms [cf. note 1], pp. 182-211, here p. 182; p. 182 f., n. 1 lists relevant studies); to be mentioned here: the basic chapter in Popkin, The History of Scepticism (cf. note 1), pp. 44-63; Vicente Raga Rosaleny, "The Current Debate About Montaigne's Skepticism,” in: Maia Neto/Paganini/Laursen (eds.), Skepticism in the Modern Age (cf. note 1), pp. 55-70; Sérgio Cardoso, “On Skeptical Fideism in Montaigne's Apology for Raymond Sebond," in: Maia Neto/Paganini/Laursen (eds.), Skepticism in the Modern Age (cf. note 1), pp. 71-82; Luiz Eva, “Montaigne’s Radical Skepticism,” in: Maia Neto/ Paganini/Laursen (eds.), Skepticism in the Modern Age (cf. note 1), pp. 83-104; Markus Wild, “Montaigne als pyrrhonischer Skeptiker," in: Wild/Spoerhase/Werle (eds.), Unsicheres Wissen (cf. note 1), pp. 109-134; as well as the more recent study: Manuel Bermúdez Vázquez, The Skepticism of Michel de Montaigne, Cham/Heidelberg/New York 2015. It is not intended to deny here that all Hellenistic philosophical schools had influence on the Essais (with regard to the reception of Stoicism, see John D. Lyons, Before Imagination: Embodied Thought from Montaigne to Rousseau, Stanford, CA 2005, pp. 32-60; for this aspect in general, see also corresponding passages in Hugo Friedrich's comprehensive study on Montaigne [Hugo Friedrich, Montaigne, 3rd ed., Tübingen/Basel 1993 (1st ed. 1949), esp. pp. 60-71, pp. 93-131, pp. 252-260, pp. $301 \mathrm{ff}]$.$) . The reception of skepticism, however, has to be considered$ 
modern age. As Christian Schärf states in his study on the history of the essay (Geschichte des Essays),

\begin{abstract}
Montaigne war nicht nur der erste, der konsequent auf die innerweltliche Dimension des empirischen Ich abgehoben, nicht nur derjenige, der die antike Skepsis in Gestalt des Pyrrhonismus in die Neuzeit hineintransponiert hat, er war darüber hinaus auf bestimmte Art und Weise der erste, der sich zu einem vollkommen autonomen Schreibakt aufgeschwungen hat. Diese drei Komponenten sind bei ihm untrennbar miteinander verknüpft $[\ldots .]^{77}$

'Montaigne was not only the first one to consistently emphasize the inner-worldly dimension of the empirical I and not only the one who transposed ancient skepticism in the shape of Pyrrhonism into the modern age but, furthermore, he was, in a certain way, the first one to soar up towards an act of writing being entirely autonomous. In Montaigne, these three components are inseparably intertwined.'
\end{abstract}

In his preface to the reader, Montaigne places the Self at the center of contemplation: "[...] je suis moy-mesmes la matiere de mon livre [...]” [I myself am the subject of my book]; and that this contemplating is characterized by playful irony becomes evident in the sentence: “Que si j'eusse esté parmy ces nations qu'on dict vivre encore sous la douce liberté des premieres loix de nature, je t'asseure que je m'y fusse très-volontiers peint tout entier, et tout nud" [(F)or had I found myself among those peoples who are said still to live under the sweet liberty of Nature's primal laws, I can assure you that I would most willingly have portrayed myself whole, and wholly naked. ${ }^{78} \mathrm{He}$ even, as the

particular, as it is expressed not only thematically, but is manifest also in the form of the Essais, in the writing itself.

77 Christian Schärf, Die Geschichte des Essays: Von Montaigne bis Adorno, Göttingen 1999, pp. $46 \mathrm{f}$.; see altogether pp. 44-63.

78 Montaigne, “Au Lecteur," in: Montaigne, Les Essais (cf. note 70), p. 27; Montaigne, “To the Reader," in: Montaigne, Essays (cf. note 70), p. liv. It should be noted here the specific reference to the 'inhabitants of the New World' in the prominent essay Des Cannibales (I, 30) (but see as well, e.g., III, 6: Des Coches [in: Montaigne, Les Essais, pp. 941-960, here pp. 952-960] and regarding what is mentioned in the following, II, 11: De la cruauté [Montaigne, Les Essais, pp. 442-457, here p. 452]). There, the 'barbaric cruelty' (cannibalism) of the 'savages' is compared with the atrocities committed in the name of the faith during the religious wars raging in France: "Je pense qu'il y a plus de barbarie à manger un homme vivant, qu'à le manger mort, à deschirer par tourmens et par gehennes, un corps encore plein de sentiment, le faire rostir par le menu, le faire mordre et meurtrir aux chiens, et aux pourceaux (comme nous l'avons, non seulement leu, mais veu de fresche memoire, non entre des ennemis anciens, mais entre des voisins et concitoyens, et qui pis est, sous pretexte de pieté et de religion), que de le rostir et manger apres qu'il est trespassé” (I, 30: Les Cannibales, in: Montaigne, Les Essais, pp. 208-221, here p. 216). The exposing of the relativity of what is described as 'barbaric' holds subversive implications insofar as, on the one hand, a critical commentary related to actuality is made possible, and on the other hand, a fixed ascription is being dismantled. (In the 
following oft-quoted passage indicates, seems to elide the Self and the text: "Je n'ay pas plus faict mon livre que mon livre m’a faict. Livre consubstantiel à son autheur: D'une occupation propre: Membre de ma vie: Non d'une occupation et fin, tierce et estrangere comme tous autres livres" [I have not made my book any more than it has made me - a book of one substance with its author, proper to me and a limb of my life (and whose business is not designed for others, as that of all other books is.)] $]^{79}$ The intention of the Essais is not to popularize a knowledge accumulated from books nor to serve as a philosophical-moral treatise with claims to universal validity. The focus is no longer on the doctrines of ancient or theological authorities functioning as guarantors of truth, but on a self-reflexive subject whose self-questioning, undertaken with a skeptical and serene attitude, leads him to explore a wide variety of topics, through which he is presented with a multitude of opinions that he then integrates into his own thinking process. In the essay called Des livres [On Books] the speaking I says with self-irony:

Je ne fay point de doute, qu'il ne m'advienne souvent de parler de choses, qui sont mieux traictées chez les maistres du mestier, et plus veritablement. C'est icy purement l'essay de mes facultez naturelles, et nullement des acquises: Et qui me surprendra d'ignorance, il ne fera rien contre moy: car à peine respondroy-je à autruy de mes discours, qui ne m'en responds point à moy, ny n'en suis satisfaict. Qui sera en cherche de science, si la pesche où elle se loge: il n'est rien dequoy je face moins de profession. Ce sont icy mes fantasies, par lesquelles je ne tasche point à donner à connoistre les choses, mais moy: elles me seront à l'adventure connues un jour, ou l'ont autresfois esté, selon que la fortune m'a peu porter sur les lieux, où elles estoient esclaircies. Mais il ne m'en souvient plus. Et si je suis homme de quelque leçon, je suis homme de nulle retention. Ainsi je ne pleuvy aucune certitude, si ce n'est de faire connoistre jusques à quel poinct monte pour cette heure, la connoissance que j'en ay. Qu'on ne s'attende pas aux matieres, mais à la façon que j’y donne. ${ }^{80}$

following, however, it also says: "Nous les pouvons donc bien appeller barbares, eu esgard aux regles de la raison, mais non pas eu esgard à nous, qui les surpassons en toute sorte de barbarie" [ibid.]).

79 Montaigne, II, 18: Du desmentir, in: Montaigne, Les Essais, pp. 702-706, here pp. 703 f.; Montaigne, II, 18: On giving the lie, in: Montaigne, Essays, pp. 753-758, here p. 755.

80 Montaigne, II, 10: Des livres, in: Montaigne, Les Essais (cf. note 70), pp. 427-441, here pp. $427 \mathrm{f}$. See in this regard as well: "Les autres forment l'homme, je le recite: et en represente un particulier, bien mal formé: et lequel si j'avoy à façonner de nouveau, je ferois vrayment bien autre qu'il n'est: meshuy c'est fait. [. . . Le monde n'est qu'une branloire perenne [...]. La constance mesme n'est autre chose qu'un branle plus languissant. Je ne puis asseurer mon object [...]. Je ne peinds pas l'estre, je peinds le passage [. . .]. [. . . Je n'enseigne point, je raconte” (Montaigne, III, 2: Du repentir, in: Montaigne, Les Essais, pp. 844-859, here pp. $844 \mathrm{ff}$.$) .$ 
'I do not doubt that I often happen to speak of things which are treated better in the writings of master-craftsmen, and with more authenticity. What you have here is purely an essay of my natural, not at all of my acquired, abilities. Anyone who catches me out in ignorance does me no harm: I cannot vouch to other people for my reasonings: I can scarcely vouch for them to myself and am by no means satisfies with them. If anyone is looking for knowledge let him go where such fish are to be caught: there is nothing I lay claim to less. These are my own thoughts, by which I am striving to make known not matter but me. Perhaps I shall maser that matter one day; or perhaps I did so one when Fortune managed to bring me to places where light is thrown on it. But I no longer remember anything about that. I may be a man of fairly wide reading, but I retain nothing. So I guarantee you nothing for certain, except my making known what point I have so far reached in my knowledge of it. Do not linger over the matter but over my fashioning of it. ${ }^{, 81}$

What is central to the skeptic project of the Essais is the movement, the process of thinking, rather than its outcome. The narrative dynamics of the Essais are characterized by structures of isosthenia and suspension of judgment; not the assertion of certainty and assurance of truth, but the renouncing of the search for truth in a reflected way, 'attempts' as the title (essais) states. The last essay of the second book refers to this writing process as fagotage (meaning nonstructured and piecemeal, fagot, bundle). It is this process that results in the sense of openness and lack of dogmatism for which the work is famous, and which not least is also reflected in the well-known genesis and edition history of the content-wise and formally heterogeneous project of the Essais. ${ }^{82}$

In his study on Montaigne (which also examines the 'motion' [mouvement] present in the Essais), Jean Starobinski examines the idea of the 'return to oneself' advocated in Montaigne's writing, particularly in reference to the chapter De la solitude (I, 38). According to Starobinski, this 'return to oneself' differed

81 Montaigne, II, 10: On Books, in: Montaigne, Essays (cf. note 70), pp. 457-471, here pp. 457 f. 82 "Ce fagotage de tant de diverses pieces, se faict en ceste condition, que je n'y mets la main, que lors qu'une trop lasche oysiveté me presse, et non ailleurs que chez moy. Ainsin il s'est basty à diverses poses et intervalles, comme les occasions me detiennent ailleurs par fois plusieurs moys. Au demeurant, je ne corrige point mes premieres imaginations par les secondes, ouy à l'aventure quelque mot: mais pour diversifier, non pour oster. Je veux representer le progrez de mes humeurs, et qu'on voye chaque piece en sa naissance" (Montaigne, II, 37: De la ressemblance des enfans aux peres, in: Les Essais [cf. note 70], pp. 796-826, here p. 796). The first edition of 1580 - in 1572, in the year of the so-called St. Bartholomew's Day Massacre, Montaigne had begun with the work on the Essais - comprised 94 chapters in two books, the fourth edition published in 1588 was supplemented by new essays in a third book (now a total of 107 chapters) as well as by numerous corrections and additions to existing texts; until his death in 1592, Montaigne incorporated further additions and changes into his hand copy, the famous Exemplaire de Bordeaux; a final version was published posthumously by his adopted daughter Marie de Gournay in 1595 (this is also the basis of the edition used here). 
from the Christian-Augustinian turning inward and did not correspond to the traditional idea of the vita contemplativa (contemplative life) as opposed to the vita activa (active life). The purpose of the latter was to enable one to be ready to listen to the voice of God, and by internalizing the submission to transcendence and the hope for salvation, whereas in Montaigne's Essais the inner 'conversation' was a self-sufficing end in itself. ${ }^{83}$ The Essais launched a tradition of secular self-representation. In this respect, they also differ from confessional literature, a genre begun with Augustine's Confessiones (c. 397-400), in which self-knowledge is considered the path to a knowledge of God, a resting in God.

It is important to re-state here that the 16th century mindset that engaged with the ancient pagan philosophical skepticism was one shaped by Christianity and its internal pluralization. This period, particularly in France, saw an everescalating and bloody religious conflict that degenerated into a series of confessional civil wars. Montaigne refers to these conflicts throughout his work ${ }^{84}$ and in fact died before they were resolved. Despite this, Montaigne's skepticism does not amount to a rejection of faith, but, in the sense of a Pyrrhonian conservatism, it 'comes to terms' with the given, in this case with traditional Christianity. ${ }^{85}$ This

83 Jean Starobinski, Montaigne in Motion [Montaigne en mouvement, 1982], trans. Arthur Goldhammer, Chicago/London 1985, p. 12 ("Montaigne's interpreters have in general been clearly aware of how this kind of 'turning inward,' derived from the teachings of the Greek and Latin philosophers, differed from that urged by Christian piety and especially by Augustinian preaching: the latter advised turning inward in order to heed the voice of God and submit to his judgment, internalizing the individual's submission to the transcendental. By contrast, the withdrawal desired by Montaigne has as its only purpose the discovery of a conversational mirror within oneself; it aims to restore full powers of judgment to the mortal individual, dividing the self between two equal powers and rejecting the claims of any outside authority. Although humanism and religion both recommend interior 'conversation' and reappropriation, from the standpoint of the believer this is but a first step, to be followed by obedience to divine authority and the hope of salvation. For the humanist who has taken his distance from religion, the inner reappropriation, if successful, is sufficient unto itself. The solitude sanctioned by humanism is not to be confused with the traditional vita contemplativa, which in the religious scheme of things was opposed to the vita activa, or life in the world."). Regarding this, see also already Zepp, An Early Self (cf. note 1), p. 103 (on De la solitude in the following: pp. 103-106).

84 See one of the many examples above note 78.

85 Cf.: “Car, quelque apparence qu'il y ayt en la nouvelleté, je ne change pas aisément, de peur que j'ay de perdre au change: Et puis que je ne suis pas capable de choisir, je prens le choix d'autruy, et me tiens en l'assiette où Dieu m'a mis. Autrement je ne me sçauroy garder de rouler sans cesse. Ainsi me suis-je, par la grace de Dieu, conservé entier, sans agitation et trouble de conscience, aux anciennes creances de nostre religion, au travers de tant de sectes et de divisions que nostre siecle a produittes" (Montaigne, II, 12: Apologie de Raimond de Sebonde [cf. note 71], p. 604); regarding the aspect of 'skeptical practice,' that is, following the rules and customs customary in the society in which one lives, see also: “[. . . le sage doit au 
is evident in the essay Apologie de Raimond de Sebonde discussed above, where he uses the argumentative instruments of Pyrrhonian skepticism to criticize any attempt to prove the truth of Christian beliefs through reason. Montaigne's skepticism has thus been termed, variously, 'Catholic Pyrrhonism,' 'skeptical Fideism,' or 'conformist Fideism,' and his writings have been read as representative, if not defending, a specific form of Fideism. ${ }^{86}$ This aspect will not be discussed further here, especially as it is problematic to insinuate that the author would have a certain intention in this regard. What is clear, however, is that the skepticism expressed in Montaigne's work found its way into the theological discourse and was taken up as a welcome argumentative tool by representatives of the Counter-Reformation in their battle of words with the Reformers. ${ }^{87}$

In the context of a dynamic, instable, pluralizing world without binding variables to provide orientation, the Essais present a subjective-skeptical perspective; they do not attempt to systematize the observed and experienced diversity but rather appear to accept with composure the multiplicity and

dedans retirer son ame de la presse, et la tenir en liberté et puissance de juger librement des choses: mais quant au dehors, qu'il doit suivre entierement les façons et formes receues. La societé publique n'a que faire de nos pensées: mais le demeurant, comme nos actions, nostre travail, nos fortunes et nostre vie, il la faut prester et abandonner à son service et aux opinions communes [...]. Car c'est la regle des regles, et generale loy des loix, que chacun observe celles du lieu où il est" (Montaigne, I, 23: De la coustume, et de ne changer aisement une loy receue, in: Montaigne, Les Essais [cf. note 70], pp. 111-127, here pp. 122 f.). See, however, as well Zepp, An Early Self (cf. note 1), p. 102 (“[...] [T] he writing 'I' [of the Apologie] appears as a Christian and a Catholic. However, this decision does not result from (ethnic) affiliation or a pre-rational clinging to tradition, but rather from the lack of a rationally based alternative option, which becomes evident in the process of writing. The textual 'I' in the Essais is based on the impossibility of a decision for anything other than the given.").

86 See, among others, Friedrich, Montaigne (cf. note 76); Popkin, The History of Scepticism (cf. note 1), p. 47 and passim ("The 'Apologie' unfolds in Montaigne's inimitable rambling style as a series of waves of scepticism, with occasional pauses to consider and digest various levels of doubt but with the overriding theme an advocacy of a new form of fideism - Catholic Pyrrhonism."); Terence Penelhum, God and Skepticism: A Study on Skepticism and Fideism, Dordrecht/Boston/Lancaster 1983, pp. 18-31 ('conformist fideism'); taking up the discussion, see, e.g.: Cardoso, “On Skeptical Fideism in Montaigne’s Apology for Raymond Sebond” (cf. note 76); for readings of the Apologie problematizing this complex of issues, see, e.g., as well the publication by A. Kablitz mentioned in note 76; reference should also be made to the abundance of secondary literature about Montaigne's skepticism mentioned there (note 76).

87 Regarding this aspect, see once more Popkin, The History of Scepticism (cf. note 1), pp. 57-79 (who also makes it clear himself: "Regardless of what personal convictions Montaigne may or may not have had, his writings were to play an enormous role in the intellectual world of the seventeenth century" [p. 57]) and see chap. 1.2 above. 
inconstancy of the world, opinions, people, and the self. ${ }^{88}$ One could describe the skeptical project of the Essais as translating the abstract notions 'relativity of perception,' 'relativity of judgments,' 'suspension of certainty,' and 'suspension of judgement' into a serene, ironic, unsystematic, self-referred narration, which integrates observations of the world and real historical references into the process of narrating and thinking together with historical anecdotes, literary and biblical quotations, and philosophical aphorisms. The lack of certainty and the experience of contingent existence do not lead to despair, nor is there an attempt to 'overcome' skeptical doubt by means of reason or faith. Instead, it is celebrated in a playful way. Considering a perception of truth as relative and not absolute, a stance that ultimately came to include traditional moral theology, ${ }^{89}$ the human being's understanding of himself appears as an independent (purely worldly) ethical dimension:

\begin{abstract}
Je propose une vie basse, et sans lustre: C'est tout un. On attache aussi bien toute la philosophie morale, à une vie populaire et privée, qu'à une vie de plus riche estoffe: Chaque homme porte la forme entiere, de l'humaine condition. [.. .] J'ay mes loix et ma cour, pour juger de moy, et m'y adresse plus qu'ailleur. ${ }^{90}$

'I am expounding a lowly, lacklustre existence. You can attach the whole of moral philosophy to a commonplace private life just as well as to one of richer stuff. Every man bears the whole Form of the human condition. [...] I have my own laws and law-court to pass judgement on me and I appeal to them rather than elsewhere. ${ }^{91}$
\end{abstract}

The presence of skepticism in Montaigne's writing is particularly attested to in a passage from the 26th chapter of the first book. This somewhat short essay,

88 For this aspect, see, e.g.: Montaigne, II, 1: De l'inconstance de nos actions, in: Montaigne, Les Essais (cf. note 70), pp. 351-358 ("Toutes les contrarietez s'y trouvent, selon quelque tour et en quelque façon: Honteux, insolent, chaste, luxurieux, bavard, taciturne, laborieux, delicat, ingenieux, hebeté, chagrin, debonaire, menteur, veritable, sçavant, ignorant, et liberal, et avare, et prodigue: tout cela, je le vois en moy aucunement, selon que je me vire: et quiconque s'estudie bien attentivement trouve en soy, voire et en son jugement mesme, cette volubilité et discordance. Je n'ay rien à dire de moy, entierement, simplement, et solidement, sans confusion et sans meslange, ny en un mot” [p. 355]; "Nous sommes tous de lopins, et d'une contexture si informe et diverse, que chaque piece, chaque moment, faict son jeu. Et se trouve autant de difference de nous à nous mesmes, que de nous à autruy” [p. 357]).

89 Regarding this, see, e.g., Montaigne, II, 12: Apologie de Raimond de Sebonde (cf. note 71), pp. 460-465, p. 527, pp. 607-611; as well as the essai quoted in the following.

90 Montaigne, III, 2: Du repentir (cf. note 80), pp. 845-848 (my italics).

91 Montaigne, III, 2: On repenting, in: Montaigne, Essays (cf. note 70), pp. 905-921, here pp. 908-911. 
though thematically close to the philosophically dense Apologie, is entitled C'est folie de rapporter le vray et le faux à nostre suffisance [It is madness to judge the true and the false from our own capacities], ${ }^{92}$ which clearly reflects characteristics of Pyrrhonian criticism. The text begins by naming (in a toposlike way) two opposing human flaws that affect the ability to judge: simplicity and ignorance on the one hand and, on the other, the presumption that those things that do not seem probable are therefore false. ${ }^{93}$

Montaigne then uses a variety of examples to develop the idea of the credibility or non-credibility of those things that appear to be inaccessible to reason, implicitly referring to central aspects of the confessional debate of the time (in particular the 'miracle' of transubstantiation as the central dogma of Catholicism). The essay ends with the following passage:

Et d'avantage, je le puis dire pour l'avoir essayé, ayant autrefois usé de cette liberté de mon chois et triage particulier, mettant à nonchaloir certains points de l'observance de nostre Eglise, qui semblent avoir un visage ou plus vain ou plus estrange, venant à en communiquer aux hommes sçavans, j'ay trouvé que ces choses là ont un fondement massif et tressolide: et que ce n'est que bestise et ignorance, qui nous fait les recevoir avec moindre reverence que le reste. Que ne nous souvient il combien nous sentons de contradiction en nostre jugement mesmes? combien de choses nous servoyent hyer d'articles de foy, qui nous sont fables aujourd'huy? La gloire et la curiosité, sont les deux fleaux de nostre ame. Cette cy nous conduit à mettre le nez par tout, et celle là nous defend de rien laisser irresolu et indecis. ${ }^{94}$

'Moreover I can say that for having assayed it; in the past I made use of that freedom of personal choice and private selection of in order to neglect certain details in the observance of our Church because they seemed to be rather odd or rather empty; then, when I came to tell some learned men about it, I discovered that those very practices were based on massive and absolutely solid foundations, and that it is only our ignorance and animal-stupidity which make us treat them with less reverence that all the rest. Why cannot we remember all the contradictions which we feel within our own judgment, and how many things which were articles of belief for us yesterday and fables for us today? Vainglory and curiosity are the twin scourges of our souls. The former makes

92 Montaigne, I, 26: C'est folie de rapporter le vray et le faux à nostre suffisance, in: Montaigne, Les Essais (cf. note 70), pp. 185-189.

93 “Ce n'est pas à l'adventure sans raison, que nous attribuons à simplesse et ignorance, la facilité de croire et de se laisser persuader [...]. [...] Mais aussi de l'autre part, c'est une sotte presomption, d'aller desdaignant et condamnant pour faux, ce qui ne nous semble pas vraysemblable [...]” (p. 185; my italics).

94 P. 189. 
us stick out noses into everything: the latter forbids us to leave anything unresolved or undecided. ${ }^{95}$

The narrating I reports that once he himself had neglected certain points of church praxis and/or dogma that seemed to him vain or strange, only to realize, after discussing the matter with learned men, that those things indeed had a solid and strong foundation and that it was only because of our stupidity and ignorance that we received them with less reverence than others (aspects of the doctrine of the faith). However, certainty is only supposedly gained here; this position is not the last word, but it is isosthenia and epoché, the skeptical suspension of judgement resulting from it, that are expressed at the end of the essay. It is the shift into a mode of questioning (Que sçais-je? [What do I know?]) that expresses the skeptical attitude: 'Que ne nous souvient il combien nous sentons de contradiction en nostre jugement mesmes? combien de choses nous servoyent hyer d'articles de foy, qui nous sont fables aujourd'huy?' [Why do we not consider what contradictions we find in our own judgments; how many things were yesterday articles of our faith, that today appear (to us) no other than fables?]. The decisive factor here is that the articulated doubt concerns not only the writing 'I,' but, by using the plural (nous), is extended to include the hommes sçavans [the learned men] that had before been the former guarantors of dogmatic certainty. The text then ends with a formulaic, epistemological (and, in the context of the Essays' enterprise, also self-ironic) statement that presumption (gloire) and curiosity (curiosité) were scourges of our soul (fleaux de nostre ame). ${ }^{96}$

\subsubsection{Francisco Sánchez’ Quod nihil scitur}

In Lyon in 1581, only a year after the first publication of the immensely successful Essais (which by 1669 had gone through no less than 37 editions), appeared the second major text of importance for Early Modern skepticism, entitled, programmatically and provocatively, Quod nihil scitur [That Nothing is Known]. This philosophical treatise was written by Francisco Sánchez (also: Sanches, 1551-1623), called 'the Skeptic' by his contemporaries. Sánchez lived in Toulouse,

95 Montaigne, I, 27: That it is madness to judge the true and the false from our own capacities, in: Montaigne, Essays (cf. note 70), pp. 200-204, here pp. $457 \mathrm{f}$.

96 See also already Zepp, An Early Self (cf. note 1), pp. 99 f. 
where he was a practicing physician as well as a professor of philosophy and medicine at the university. ${ }^{97}$ Montaigne's Essais constitute a separate literary

97 Whether Franciscus Sanchez - this is the name given in his publications, all of which were written in Latin - is to be regarded as a Spaniard (Sánchez) or a Portuguese (Sanches) is a controversial question and is therefore usually reflected in the spelling of his name. (Even though the Spanish spelling is used here, this is not intended to be a determination in the sense of a 'national origin.' Quod nihil scitur bears witness to the prevalence of skepticism in the second half of the 16th century as a Europe-wide phenomenon.) Sánchez was born in the Spanish-Portuguese border region (in Tuy, on the Spanish-Galician side of the Miño border river, or in Braga, on the territory of Portugal) presumably into a Spanish family of conversos, who emigrated to Bordeaux in the early 1560s (probably as a result of the increasingly repressive approach of the Portuguese authorities that culminated with the establishment of the Inquisition in Portugal in 1536). There, Sánchez attended the famous Collège de Guyenne, where Montaigne had studied twenty years earlier. (Although a distant relationship between the two, through Montaigne's mother's family, has been posited, there is no evidence that they knew each other or exchanged ideas together. It is likely, however, that Montaigne knew of Sánchez' text, even if he does not explicitly mention it, at the time of the publication of the second edition of the Essais.) Sánchez studied medicine in Rome, among other places, and obtained his doctorate at the famous medical faculty of the University of Montpellier. Although teaching there, he did not receive the hoped-for professorship. He left the Huguenot Montpellier, marked by religious conflict, and settled in the Catholic city of Toulouse in 1575. For thirty years he worked as a doctor at the Hôtel-Dieu, the municipal hospital; his university activities in Toulouse began in 1585, when he was offered the chair of philosophy, and where from 1612 until his death in 1623 he held a professorship in medicine. In addition to his principal skeptical work, Quod nihil scitur, which was already available in manuscript form in 1574 (thus in close proximity to Montaigne's Essais), Sánchez wrote several philosophical as well as medical treatises; in 1636, the collected writings published by his sons appeared in Toulouse (Opera Medica: His iuncti sunt tractatus quidam philosophici non insubtiles). Worth mentioning is the Epistula ad Clavium (Letter to Christoph Clavius [1538-1612], one of the famous astronomers and mathematicians of the 16th century), a text that appears to be particularly interesting with regard to Descartes: Sánchez calls himself 'Carneades Philosophus' there, thus giving himself the name of one of the most important ancient Academic skeptics (Carneades of Cyrene) and critically examining the claims to certainty of mathematics. Pierre Bayle (1647-1706), in his Dictionnaire, considered Sánchez a 'great skeptic' or 'great Pyrrhonian' - the terms were used synonymously in the 16th and 17th centuries: "SANCHEZ (François) [...] C'étoit un gran Pyrrhonien [...]" [He was a great Pyrrhonian] (Pierre Bayle, Dictionnaire historique et critique, 4 vols., 5thed. Amsterdam 1740 [1st ed. 1697 (2 vols.)], vol. 4, pp. 133 f.). The dissemination of Quod nihil scitur throughout Europe is attested to not only by the number of editions (among others, Frankfurt 1618; Rotterdam 1649) but also by the fact that the text was the subject of much anti-skeptical discourse in the 17th century (see for example, these refutation attempts published in Germany: Ulrich Wild, Quod aliquid scitur, Leipzig 1664; Daniel Hartnack, Sanchez aliquid sciens, Szczecin 1665); a possible relation to Descartes is still to be discussed. This outline is based on the accounts in: Manuel Bermúdez Vázquez, La fuerza de la duda: Francisco Sánchez el escéptico, Madrid 2013, pp. 17-35; Kaspar Howald, "Einleitung," in: Francisco Sánchez, Quod nihil scitur/Daß nichts gewußt wird, introd. and ed. Kaspar Howlad, trans. Damian Caluori and Kaspar Howald, Latin 
genre that conveyed, particularly in the Apologie, the 'theory' and 'practice' of Pyrrhonian skepticism in an Early Modern, Christian context, and examined a variety of issues - philosophical, theological, scientific, ethical or political through a skeptical lens. Sánchez, however, focused exclusively on the epistemological dimension. His treatise was written in Latin and intended for an academic audience. It had a radically anti-Aristotelian and decidedly anti-scholastic impetus, but it was also, as scholarship repeatedly indicates, "a philosophical work in its own right." 98

The text's 'Preface to the Reader' opens with a quotation of the first sentence of Aristotle's Metaphysics: "Innatum hominum velle scire: paucis concessum scire velle: paucioribus scire" ['Mankind has an inborn desire to know'; to but a few has been granted the knowledge of how to desire; and to fewer still has it been granted to know]. ${ }^{99}$ Given that the goal of the treatise appears to be

text ed. Sergei Mariev, Hamburg 2007, pp. IX-CLXIII, esp. pp. IX-XXXIX; Elaine Limbrick, "Introduction,” in: Francisco Sánchez, That Nothing Is Known (Quod Nihil Scitur), ed. Elaine Limbrick, Latin text ed. and trans. Douglas F. S. Thomson, Cambridge/New York/New Rochelle 1988, pp. 1-88, esp. pp. 1-24, pp. 47-50, pp. 84-87; Popkin, The History of Scepticism (cf. note 1), pp. 38-43; see also the chapter on Sánchez in: Eloy Bullón y Fernández, Los precursores españoles de Bacon y Descartes, Salamanca 1905, pp. 153-192, here pp. 153-160; for a comparison Montaigne/Sánchez, see, e.g., Gianni Paganini, Skepsis: Le débat des modernes sur le scepticisme, Paris 2008, pp. 15-60 (“Chap. I: La redécouverte du phénomène - Montaigne vs Sanches"); see also with regard to the impact of being a converso on Sánchez' (and Montaigne's) thinking ("It seems that it was in Bordeaux, in the avant-guarde intellectual atmosphere of the newly arrived converso population - particularly at the Collège de Guyenne - that the skeptical problem was first identified and properly formulated, thus unleashing the skeptical crisis that would rage through seventeenth century Europe.”) and for an analysis of Sánchez' philosophy with respect to elements referring to a Jewish tradition: Faur, In the Shadow of History (cf. note 1), pp. 87-109 (quote p. 109).

98 Here in Popkin's formulation (The History of Scepticism [cf. note 1], p. 39).

99 The Latin text as well as its English translation are quoted from the edition: Francisco Sanches (Franciscus Sanchez), That Nothing Is Known (Quod Nihil Scitur), ed. Elaine Limbrick, ed. Latin text and trans. Douglas F.S. Thomson, Cambridge/New York/New Rochelle 1988, here p. 92/p. 166 ("Franciscus Sanchez Lectori S[alutem]," pp. 92-95; "Francisco Sanches to the Reader, Greetings,” pp. 166-172; italics in the original). Cf. Aristotle, Metaphysica 980a 21 (I, 1) (Aristotle, Metaphysics, trans. William D. Ross, in: [Aristotle], The Complete Works of Aristotle: The Revised Oxford Translation, ed. Jonathan Barnes, 6th ed., 2 vols., Princeton, NJ 1995, vol. 2, pp. 3343-3716, p. 3343: "All men by nature desire to know.”). Montaigne also begins the last of his Essais, which discusses 'experience,' with this quote of Aristotle (Montaigne, III, 13: De l'Experience, in: Montaigne, Les Essais [cf. note 70], pp. 1111-1167, here p. 1111: "Il n'est desir plus naturel que le desir de cognoissance."). It is this essai that is thought to be an indication that Montaigne knew Quod nihil scitur. Furthermore, reference has been made to the similar empirical-like conclusion (which is still to be explained in regard to Sánchez) that concrete experience could provide a possible ground for knowledge (see 
to undermine Aristotelian epistemology (and thus the basis of contemporary science and guarantee of human cognitive ability implicit in the quote from Aristotle), it must be read as ironic-programmatic. Sánchez then goes on to inform his readers that his thirst for knowledge, which he had from very early on, was quickly stymied by the lack of satisfactory results. Having examined the teachings of the ancients and of his contemporaries, he "[...] found not one who gave an honest and full report of the judgments one ought to form concerning facts (res)." The account of his experience and his subsequent reaction show obvious parallels to the self-presentation given in Descartes' Discours:

Subsequently I withdrew into myself; I began to question everything, and to examine the facts themselves as though no one had ever said anything about them, which is the proper method of acquiring knowledge. I broke everything down into its ultimate first principles. Beginning, as I did, my reflection at this point, the more I reflected the more I doubted. I was incapable of grasping anything in its whole nature. I was in despair, but I still persisted. ${ }^{100}$

Limbrick, "Introduction” [cf. note 97], pp. 80 f. with notes 41 and 43; Howald, "Einleitung” [cf. note 97], pp. XVI f. with note 15).

100 Sánchez, That Nothing Is Known (Quod Nihil Scitur) (cf. note 99), p. 167. "A prima vita, Naturae contemplationi addictus minutim omnia inquirebam. Et quāuis initio adidus animus sciendi quocumque oblato cibo contentus esset utcumque: post modicum tamen tempus indigestione praehensus reuomere coepit omnia. Quaerebamque iam tunc quid illi darem quod \& perfecte amplecteretur, \& fruerectur absolute: nec erat qui desiderium expleret meum. Euoluebam praeteritorum dicta, tentabam praesintiū corda: idem respondebant: quod tamen mihi satisfaceret, omnino nihil. [...] nullū tamen inueni, qui quid de rebus iudicandum sincere, absoluteque proferret. Ad me proinde memetipsum retuli; omniaque in dubium reuocans, ac si a quopiam nil unquam dictum, res ipsas examinare coepi: qui verus est sciendi modus. Resoluebam usque ad extrema principia. Inde initium contemplationis faciēs, quo magis cogito magis dubito: nil perfecte complecti possum. Despero. Persisto tamen” (p. 92). Descartes' engagement with skepticism will be discussed in detail in the following sub-chapter; however, since the explanations there do not explicitly include the above-mentioned (more extensive) Discours I, exemplary excerpts are quoted here for illustration: "J'ai été nourri aux lettres dès mon enfance, et pource qu'on me persuadait que, par leur moyen, on pouvait acquérir une connaissance claire et assurée de tout ce qui est utile à la vie, j'avais un extrême désir de les apprendre. Mais, sitôt que j'eus achevé tout ce cours d'études, au bout duquel on a coutume d'être reçu au rang des doctes, je changeai entièrement d'opinion. Car je me trouvais embarrassé de tant de doutes et d'erreurs, qu'il me semblait n'avoir fait autre profit, en tâchant de m'instruire, sinon que j’avais découvert de plus en plus mon ignorance. [. . .]"; "Mais après que j'eus employé quelques années à étudier [...] dans le livre du monde et à tâcher d'acquérir quelque expérience, je pris un jour résolution d'étudier aussi en moi-même, et d'employer toutes les forces de mon esprit à choisir les chemins que je devais suivre. [. . .]" (René Descartes, Discours de la Méthode, in: René Descartes, Euvres, ed. Charles Adam and Paul Tannery, 13 vols., Paris 1897-1913, vol. 6 [1902]: Discours de la Méthode \& Essais, pp. 1-78, here p. 4 and pp. 10 f.)/‘From my childhood 
It must be pointed out here that while for Descartes self-referentiality and 'hyperbolic doubt' are the basis for 'overcoming' doubt reached by the cogito, Sánchez' quo magis cogito magis dubito [the more I think, the more I doubt] reads like a skeptical counter-argument ante litteram. The quote articulates a skeptical attitude in the sense of doubt about the possibility of finding a 'right method of (possible) knowledge' and not, as postulated by Descartes, the certainty of actually having found it. ${ }^{101}$

After clarifying his deliberate turning away from authorities as guarantors of certainty and from the method of scholastic reasoning (logic only results in "a maze of words, without any foundation in the truth"102), and having addressed the reader as an ally in conceiving of res (things) that is exclusively "under the guidance of sense-perception and reason" and in "doubts concerning the nature of things," 103 the intention of the quest is made explicit:

I have been nourished upon letters, and because I was persuaded that by their means one could acquire a clear and certain knowledge of all that is useful in life, I was extremely eager to learn them. But as soon as I had completed the course of study at the end of which one is normally admitted to the ranks of the learned, I completely changed my opinion. For I found myself beset by so many doubts and errors that I came to think I had gained nothing from my attempts to become educated but increasing recognition of my ignorance. [...]'; 'But after I had spent some years pursuing these studies in the book of the world and trying to gain some experience, I resolved one day to undertake studies within myself too and to use all the powers of my mind in choosing the paths I should follow [...]' (René Descartes, Discourse on the Method, in: [René Descartes], The Philosophical Writings of Descartes, trans. John Cottingham, Robert Stoothoff, and Dugald Murdoch, 3 vols., Cambridge/London/New York 1984-1991, vol. 1, pp. 111-151, here p. 112 and p. 116). Howald points to the fact that the two texts belong to the genre of intellectual autobiography dating back to Galen and their strategic self-representation (Howald, "Einleitung” [cf. note 97], p. LXIII).

101 For this aspect, see also Howald, "Einleitung” (cf. note 97), pp. LXIII f.

102 Sánchez, That Nothing Is Known (Quod Nihil Scitur) (cf. note 99), p. 168; “[. . . ex his alias inferunt: \& ex his iterū alias; nil in rebus perpendentes, quousque labyrinthum verborum absque aliquo fundamento veritatis produxere: ex quo tandem non res intelligas naturales; sed nouarum rerum, fictionumque texturam discas: quibus intelligendis nulla sufficiat mens. Quis enim quae non sunt intelligat?” (p. 92). It should also be noted that there can already be observed here a reference to nominalism (res [. . . q quae non sunt [non-existing things]).

103 "Cum iis igitur mihi res sit, qui nullius addicti iurare in verba magistri, proprio marte res expendunt, sensu, rationeque ducti. Tu igitur quisquis es eiusdem mecū conditionis, temperamentique: quique de rerum naturis saepissime tecum dubitasti, dubita modo mecum: ingenia nostra, naturamque simul exerceamus. Sit mihi liberum iudicium, non irrationabile tamen. Tibi tale \& concedo, \& precor” (p. 93)/“Accordingly, I would address myself to those who, "not bound by an oath of fidelity to answer master's words', assess the facts for themselves, under the guidance of sense-perception and reason. You, reader, whoever you may be, who share my situation and disposition, who have very often entertained private doubts concerning the nature of things - share, now, my doubts too. Let us together apply our intellectual gifts and our 
Yet all the same I make no general promise that I shall therefore give you the Truth, for I am ignorant of her, as I am of everything else. Still, I will pursue my enquiry to the best of my powers; and you for your part shall be pursuing Truth [...]. Yet you are not to expect ever to capture her, or with full knowledge lay hold on her; let the chase suffice for you, as it does for myself. For me this is the aim and the end; an aim and an end, which you too must seek. ${ }^{104}$

He then goes on to emphasize a central point of reference in his approach, namely, medicine, and particularly the connection of philosophy and medicine and thus also the envisaged practical 'benefit' of the undertaking. ${ }^{105}$ Any rejection of authority in the field of science, however, did not apply to the realm of faith, as Sánchez emphasizes: "I shall follow Nature alone. Authority bids us believe, whereas Reason demonstrates; the former is more suited to faith, the latter to the sciences." ${ }^{106}$

The structure of the text underlines its skeptical orientation. It is designed dialogically, whereby on the one hand it is not always possible to clearly determine which utterances are to be assigned to 'Sánchez' or the textual I, respectively, and which to the fictus interlocutor; on the other hand, the imaginary interlocutor/reader or the imaginary interlocutors/readers take on different functions and roles, and act, for instance, as a (sometimes also mocked) counterpart; Aristotle or representatives of an Aristotelized scholasticism, function

natural inclinations. Give me leave to judge freely, so long as I do not depart from rationality; and I both grant you, and wish for you, the same” (pp. $168 \mathrm{f}$.).

104 P. 170. "Nec proinde tamen Veritatem tibi omnino polliceor, ut qui eam, ut alia omnia, ignorem: inquiram tamen in quantum potero: tuque utcumque apertam, \& e latebris excussam persequeris. Nec tamen eam arripere speres unquam, aut sciens tenere: sufficiat tibi quod \& mihi, eandem agitare. Hic mihi scopus, his finis est: hunc tu quaerere etiam debes” (p. 94).

105 "Quo posito, a principiis rerum exordium sumentes, grauiora Philosophiae capita examinabimus, ex quibus facilius reliquia colligi possint. Nec enim in his inmorari in votis est omnino: ad Medicam quippe artem viam affectamus, cuius professores sumus: cuiusque principia omnia Philosophicae contemplationis sunt: ut eadem manu duos simul moueamus lapides: nec enim aliter vita sufficeret” (p. 94)/“This established, we shall begin with the first principles of things, and shall investigate the more important topics of philosophy, to the end that from them other questions may more easily be deduced; for it is in no way to my purpose to linger over them, since the goal of my proposed journey is the art of medicine, which I profess, and the first principles of which lie entirely within the realm of philosophical contemplation. Thus we shall kill two birds with one stone" (p. 171). This connection is an aspect that in particular Limbrick ("Introduction" [cf. note 97]) elaborates on.

106 P. 172 (italics in the original). "Solam sequar ratione Naturam. Autoritas credere iubet; ratio demonstrat: Illa fidei; haec scientiis aptior” (p. 94). 
as an interested, supportive student and as an accomplice in the search for truth, or as frame of reference in an inner monologue. ${ }^{107}$

The text begins with a statement relativizing the dogmatic implication of the title: "Nec unum hoc scio, me nihil scire: Coniecto tamen nec me, nec alios. Haec mihi vexillum propositio sit, haec sequenda venit, Nihil scitur” [I do not know even this one thing, namely that I know nothing. I infer, however, that this is true both of myself and of others. Let this proposition be my battle colour - it commands my allegiance - 'Nothing is known.'] ${ }^{108}$

107 For this, see the observations in Howald ("Einleitung” [cf. note 97], pp. XLV-XLIX), who also refers to the tradition of the diatribe as well as to the tradition of the ad hominemargumentation.

108 Sánchez, That Nothing Is Known (Quod Nihil Scitur) (cf. note 99), p. 95; pp.172 f. (italics in the original). The opening sentence is - without this being indicated as such - a quotation attributed to Metrodorus of Chios (c. 5th-4th century BC), a student of Democritus, which is mentioned in Diogenes Laertius (Vitae et sententiae philosophorum IX, 10 [58]), in Cicero's Academica (II, 73), and also in Sextus Empiricus (Adversus Mathematicos VII, 88). The sentence 'Nihil scitur' inheres a self-contradiction, which is problematic from a skeptical point of view, if it is expressed with a claim to truth. The quotation cited above is succeeded by the following, which is marked in the marginal note as "Ambigua consequentia" [ambigue conclusion]: "Hanc si probare sciuero, merito concludam, nil sciri: si nesciuero, hoc ipso melius: id enim asserebam” (p. 95)/“If I come to know how to establish this, I shall be justified in drawing the conclusion that nothing is known; whereas if I do not know how to establish it, then all the more so - for that was what I claimed" (p. 173; italics in the original). Here the 'shifting' of the dogmatic assertion that 'nothing is known' (it is that of the dogmatic skeptics, those associated with Academic skepticism) to a logical-argumentative 'truth' becomes apparent. But it is not about 'demonstrating' (demonstrare) in the Aristotelian sense (as 'a syllogism that gives birth to knowledge'); this will be one of those elements in the Aristotelian scholastic system of knowledge that will later be removed from its postulate of certainty, but rather about a logicalargumentative making plausible without an absolute claim to knowledge (probare). With ironic wit and already giving a sense of the style and argumentation strategy of the entire treatise against any claim to perfect knowledge, the text continues: "At dices: si probare scias, contrariū sequetur, aliquid enim scis iam. At ego cōtra prius conclusi, quam tu argueres. Iam incipio turbare rem: Ex hoc ipso iam sequitur, nil sciri. Forsan non intellexisti, meque ignarum aut cauillatorem vocas. Verum dixisti. Melius ego te, quia non intellexisti. Ignari igitur ambo. Iam ergo nesciens concluisti quod quaerebam. Si intellexisti ambiguitatem consequentiae, aperte vidisti, nil sciri. sin minus, cogita, distingue, \& mihi solue nodum. Acue ingenium” (p. 95)/“But you will say, 'If you know how to establish it, this will result in a contradiction, for you already know something.' I have, however, anticipated your objection by coming to the opposite conclusion. Now I begin to upset the argument: it already follows, from this very consideration, that nothing is known. Perhaps you have failed to grasp my meaning and are calling me ignorant, or a quibbler. You have told the truth; but I have a better right to say this of you, since you have failed to understand. So we are both ignorant. This being so, you have unwittingly arrived at the conclusion I was looking for. If you have understood the ambiguity of the inference, you have clearly perceived that nothing is known; if not, then ponder, make 
What follows is a systematic attack on claims to certainty and the contemporary understanding of science. This is carried out under the skeptical vexillum, "[...] the name; for as far as I am concerned every definition, and almost every enquiry, is about names. More fully: we cannot comprehend the natures of things; at least, I cannot." ${ }^{109}$ Quod nihil scitur also contains a radical critique of language. ${ }^{110}$ This is followed by a primarily nominalist polemic against the Aristotelian-scholastic knowledge system and its theory of definitions and categories, including syllogistic reasoning, conception of the understanding of causes and principles and the conception of science. ${ }^{111}$ After problematizing the axioms of Aristotelian science and thus explaining the "[. . .] ignorance of others in relation to the definition of knowledge [science] and the nature of understanding [...]," the second step would consist of portraying his "own ignorance" in order to show "[. . ] how completely we lack knowledge. [...]."112 The

a distinction, and untie this knot for me. Sharpen your wits" (p. 173; italics in the original). (Regarding the opening passage and what is said here, see Howald, "Einleitung” [cf. note 97], pp. XL-XLIII; Limbrick, "Introduction” [cf. note 97], p. 65 and her commentary in the English translation: Sánchez, That Nothing Is Known (Quod Nihil Scitur) [cf. note 99], pp. 172 f., note 20; see also Agostino Lupilo, “Humanus Animus Nusquam Consistit'. Doctor Sanchez's Diagnosis of the Incurable Human Unrest and Ignorance,” in: Paganini/Maia Neto [eds.], Renaissance Scepticisms [cf. note 1], pp. 149-179, here p. 158).

109 Sánchez, That Nothing Is Known (Quod Nihil Scitur) (cf. note 99), p. 174 (italics in the original). "A nomine rem ducamus. Mihi enim omnis nominalis definitio est, \& fere omnis quaestio. Explico. Rerum naturas cognoscere non possumus, ego saltem” (p. 95).

110 See also the later reflection dedicated decisively to the topic of language (Sánchez, That Nothing Is Known (Quod nihil scitur), pp. 119-121; pp. 216-220).

111 See Sánchez, Quod nihil scitur, pp. 96-110; pp. 175-199. A detailed account of the argumentation leading to the 'nihil ergo sciunt' (among others, with the reference points "Tu tamen diffinitionem dicis esse quae rei naturam demonstrat" [p. 95]/“You, however, claim that there is a definition which 'demonstrates the nature of a thing"” [p. 174]; "Quid igitur ille? Scientia habitus per demonstrationem acquisitus” [p. 97]/“What, then does [Aristotle] say? 'Knowledge [science] is a mental disposition, acquired by demonstration"” [p. 178]; "Iā quid illud est: Demonstratio? Diffinies iterū, Syllogismus scientiā pariens” [p. 99]/“What, now, is the thing called a 'demonstration'? You will define it afresh as follows: 'a syllogism that gives birth to knowledge [science]"' [p. 181]) shall be omitted here. It should be noted that not only is Aristotle's dominant authority in the scholastic system challenged, so is the Platonic 'doctrine of science,' the idea that knowledge is a remembering, (using, among others, the skeptical argument of regressus ad infinitum) deprived of its basis of certainty (see pp. 106-108; pp. 192-195).

112 P. 200 ("Hucusque enim aliorum ignorantiam, circa scientiae definitionem, cognitionemque subinde ostendi: nunc meam proferam, ne solus ego scire aliquid videar. Ex quo videre poteris quam inscientes simus" [p. 110]). This according to the explanation articulated at the beginning: "Quae enim hucusque a pluribus recepta fuere, mihi falsa videntur, ut iam ostendi: quae deinceps dicam, vera. Forsan contrarium iudicabis tu, \& fortassis verum erit hoc: unde sequitur confirmatio propositi, Nil sciri” (pp. 110 f.)/“Now, the doctrines that have hitherto 
starting point of the subsequent systematic critique of knowledge is a (nominal) definition of knowledge or science, respectively, formulated on its own and qualified as an "easy [...] explanation": "SCIENTIA EST REI PERFECTA COGNITIO” [Knowledge (science) is perfect understanding of a thing]. ${ }^{113}$ This, however, does not suspend skeptical doubt, whose continuous presence can be seen, for example, in the question of what 'understanding' (cognitio) is and how it should be defined:

But I do not know what "understanding" is; define it for me. I should call it comprehension or perception or "intellection" of a thing, and anything else that means what these words mean. If you are still in doubt about this, I will be silent; but I shall ask you for another definition, and if you reply to my request I will raise a doubt about your statement. Thus we are always in difficulties because of our ignorance. [...] When, afterwards, I discuss understanding with you, $I$ suppose it to be such as I have grasped, while you suppose it to be such as you have grasped. I assert that it is this, while you, on the other hand, assert that it is that. Who is to arbitrate the dispute? ${ }^{114}$

Sánchez then carries out a detailed analysis of the possibility (or impossibility) of knowledge in accordance with the formulated hypothesis, i.e., on the basis of its components: "Accordingly, if you grant my definition, there are three factors in knowledge: the thing that is to be known [res scienda]; understanding (cognitio); and the perfection of knowledge [perfectum]. We shall have to consider each of them singly, in order that we may deduce that nothing is known." 115 In the problematization of assured knowledge, the difficulties arising from the object, the thing to be apprehended (res cognita) ${ }^{116}$ are dealt with first, then the aspect of

been accepted by the majority appear to me false, as I have already shown, whereas those I am about to formulate appear to me true. Perhaps you will take the opposite view, and it may be that this will be the true one - from which results the confirmation of the proposition that 'nothing is known'” (p. 200).

113 P. 111; p. 200 (capital letters in the original; for the status of the sentence as a nominal definition, see: "Ecce facilem, veram tamen nominis explicationem” [p. 111]/“There you have an easy, yet true, explanation of the term [...]” [p. 200]).

114 P. 200 f. (italics in the original). "Sed nescio quid sit cognitio, defini mihi. Dicerem rei comprehensionem, perspectionem, intellectionem, \& si quid aliud est, quod idem significet. Si de hoc adhuc dubites, tacebo: sed petam a te aliud. Si dederis, de tuo dubitabo: sicque perpetua laboramus ingorantia. [...] Dum de cognitione postea tecum loquor, qualem comprehēdi, talem suppono: tu contra qualem tu. Hoc ego assero eam esse: tu contra illud. Quis componet litem?” (p. 111).

115 Pp. 203 f. "In scientia igitur, si definitionem admittas meam, tria sunt, res scienda, cognitio, \& perfectum: quorum quodlibet singillatim nobis expēdendum erit, ut inde colligamus nihil sciri” (p. 113).

116 Pp. 113-131; pp. 204-238. 
knowledge (cognitio), where in the presentation of the real reasons preventing knowledge a distinction is made between the act of apprehending (cognitio ipsa) ${ }^{117}$ and the apprehending subject, the person that understands (cognoscens). ${ }^{118}$

In the course of this argument - as in the first part of the treatise that questions knowledge based on authority - numerous skeptical topoi are applied, as for example in the context of the discussion of the unreliability of sensory perception. ${ }^{119}$ Sánchez does not explicitly refer to the central texts of ancient skepticism, inasmuch as neither the writings of Sextus Empiricus nor Cicero's Academica are mentioned in Quod nihil scitur. However, there are references to other ancient texts that were familiar with skepticism, such as: Diogenes Laertius' Vitae et sententiae philosophorum, Plutarch's Lucullus and Adversus Colotem, and Galen's De optima doctrina. ${ }^{120}$ Scholars are still divided as to whether the skepticism developed in Quod nihil scitur is more aligned with the Pyrrhonian or the Academic traditions, and even whether Sánchez saw himself as related to one or the other of these schools. ${ }^{121}$

117 Pp. 131-141; pp. 238-254.

118 Pp. 141-163; pp. 254-289.

119 Pp. 135-142; pp. 245-254 (this in connection with the analysis of the 'act of cognition').

120 Limbrick (“Introduction" [cf. note 97], p. 64 with note 63) notes that Erasmus' translation of Galen's De optimo docendi genere was contained both in the edition of 1562 of the Hypotyposes Pyrrhonianae and in the edition of Sextus' writings of 1569, so that Sánchez might have read Sextus Empiricus 'in the original' after all. However, the skeptics are not mentioned often in Quod nihil scitur (the Pyrrhonians four times, the Academics twice, and in fact together with the Pyrrhonians). For example, in a passage where Socrates ('I know that I know nothing') is characterized as being 'most wise,' Sánchez also points out the difference to his own project: "Now, what I have always most earnestly looked for in anyone is what I am doing, namely that he should truly say whether he knew anything completely. But such a person I have nowhere found, save for that wise and honest man Socrates (though the Pyrrhonians, and the Academic school, and the so-called sceptics, and Favorinus too, made the same assertion), who knew only this, that he knew nothing. For this saying alone he earns in my opinion the supreme place among mankind of wisdom; yet even so, he has not fully satisfied my mind, since he was ignorant even of that one fact, just as he was of others. But it was in order the more positively to assert that he knew nothing, that he said he knew that one fact. Accordingly, since he knew nothing, he dicided not to write down for us moderns to read" (Sánchez, Quod nihil scitur, p. 184) ("Hoc enim unum semper maxime ab aliquo expetiui, quod modo facio, ut vere diceret an aliquid perfecte sciret: nusquam tamen inueni, praeterquam in sapienti illo, proboque viro Socrate, (licet \& Pyrrhonij, Academici, \& Sceptici vocati, cum Fauorino id etiam asserent) qui Hoc unum sciebat, quod nihil sciebat. Quo solo dicto mihi doctissimus iudicatur: quāquam nec adhuc omnino mihi explerit mentem: cum \& illud unum, sicut alia, ignoraret. Sed ut magis assereret se nil scire, illud unum se scire dixit: qui proinde quum nihil sciret, nihil nobis scribere voluit” [p. 101]).

121 For this aspect, see Howald, "Einleitung" (cf. note 97), pp. LXXII-LXXXVIII. 
The Ockhamist-Nominalist nescio appears to be hinted at in the guiding principle quod nihil scitur. Man's 'not knowing' in the face of the contingency of the world and an unlimited all-powerful and omniscient God is not, however, the central underlying thesis of Sánchez' text, nor can it properly be classified as a work of Christian-skeptical fideism. ${ }^{122}$ The omniscience of God is stressed (as well as the unquestionable truth of Holy Scripture), but this occurs in the context of a critique of the reliability of human cognitive faculty and the established sciences: "[...] Sanches rarely indulges in metaphysical discussion and, whenever he does, it is with the object of refuting Aristotle or Galen." "123 Two arguments in this context are worth mentioning, both recall the (theological) nominalist discourse mentioned previously and refer to the discovery of new worlds; as discussed earlier in the chapter, these discoveries were the cause of significant uncertainty experienced in this period (epistemologically and in terms of faith).

Nay, perhaps there are (or have been, or will be) some others still more unlike us than they are, in some part of the world not yet discovered by us. For who can state anything with certainty about all that was, is, or will be? ${ }^{124}$

Yesterday you said in the light of your complete scientific knowledge - or rather, knowledge that was complete even long ages ago - that the entire earth was surrounded by the Ocean; and you divided it into three all-embracing parts, namely Asia, Africa, and Europe. But what are you to say today? A new world has been discovered - new realities in New Spain or in the West and East Indies. ${ }^{125}$

The phrase 'Deus omnia novit' [God knows everything] appears a few passages later in the marginalia, mentioned to show the ignorance in things and man's

122 See Limbrick, "Introduction” (cf. note 97), pp. 73 f.; Popkin, The History of Scepticism (cf. note 1), p. 43; Howald, "Einleitung” (cf. note 97), pp. LI ff. (there are also references to opposing positions).

123 Limbrick, "Introduction” (cf. note 97), p. 74.

124 Sánchez, That Nothing Is Known (Quod Nihil Scitur) (cf. note 99), p. 221; my italics (“[...] quin \& aliqui forsan sunt alij magis his a nobis diuersi in aliqua orbis parte, nobis nondum aperta, aut fuere, aut erunt. Quis enim de omni quod fuit, quod est, aut quod erit certum quid proferre potest?" [p. 122, my italics]). The sentence is also given in the marginalia: "Nullus de omni quod fuit, quod erit, certum quid dicere potest" [No one can say anything certain about all that has been and will be].

125 Pp. 221 f.; my italics. "Dicebas heri perfecta scientia tua, imo \& a plurimus saeculis, totam terram Oceano circumflecti, eamque in tres diuidebas partes uniuersales, Asiam, Aphricam, Europam. Nunc quid dices? nouus est inuentus mundus, nouae res, in noua Hispania, aut Indiis Occidentalibus, Orientalibusque” (p. 122; my italics). 
lack of the ability of cognition. Due to a lack of proportionality man cannot apprehend the perfect and sublime God and anything that comes close to him. ${ }^{126}$

Throughout the treatise it engages with the posited definition (scientia est rei perfecta cognitio [knowledge (science) is perfect understanding of a thing]); the use of conclusions such as 'nihil scitur' (and its variants, such as 'Nihil ergo scimus,' 'Quid ergo scimus? Nihil,' 'ergo nil scis,' and so on) makes it clear that there is no scientia in the sense of a rei perfecta cognitio (and probably cannot exist either). The aspect of perfection, the last element of the definition, is then summarized at the end: "And no one doubts that scientific knowledge ought to be a perfect form of 'cognition'; but what that is, and where and in what it is about this there is the greatest doubt. This too, like other things, is unknown. Perhaps it does not exist anywhere, and this is the more reasonable position." For "perfect cognitive understanding (cognitio)" requires "a perfect 'cognising' subject (cognoscens)" and a "[duly arranged] object to be 'cognised'," that is "[something perfect] in Nature."127 This implies that any knowledge man can gain about the world can only approximate perfection. The abandonment of the claim to truth in favor of probability is an expression of the probabilism of Academic skepticism. By abandoning Aristotelian-scholastic essentialism and its methods of supposed knowledge acquisition, by recognizing the limitations of one's own cognitive faculties and those of potential objects of cognition, there still remains, as the text tends to suggest, certainly the possibility of (imperfect, limited) knowledge achieved through one's own observation of nature

126 “[N]obis autem cum Deo nulla proportio, quemadmodum nec finito cum infinito, nec corruptibili cum aeterno: denique eius collatione nihil potius sumus quam aliquid. Hac eadem ratione ille omnia novit, ut qui omnibus maior, superior, praestantior, aut melius, ne collationem cum creaturis facere videar, maximus, supremus, praestantissimus sit. Quaecumque summo huic optifici propinquiora sunt, ea ratione nobis incognita etiam sunt” (p. 124)/“[T]o us, however, there is no proportion in relation to God, since there can be no proportion between the finite and the infinite, or the corruptible and the eternal; in a word, compared to Him we are nothing, rather than something. On the same principle, God knows everything, inasmuch as he is greater, higher, and most excellent of all. Whatever things approach more closely to this Supreme Artificer are for that very reason also unknown to us” (pp. 224 f.).

127 P. 289; italics in the original. "Et quod perfecta esse debeat cognitio scientia, nulli dubium: quae autem illa sit, ubi, \& in quo, maximum. Sicut \& alia, hoc etiam ignoratur. Forsan nulibi est: \& hoc magis rationale. Diximus partim supra: Perfecta cognitio perfectum requirit cognoscentem, debiteque dispositam rem cognoscendam: quae duo nusquam vidi. $\mathrm{Si}$ vidisti tu, scribe mihi. Nec hoc solum: sed an videris perfectum quid in natura. Illud autem requiri vidisti iam supra, nec proinde necesse est hic repetere” (p. 163). For the mentioned aspects, see pp. 142-147; pp. 256-264 (among other things, a perfect body would be a prerequisite, since the human soul needed the most perfect body for knowledge; furthermore: God alone is perfect). 
(of the individual things), concrete experience, and evaluation of the empirical observations. $^{128}$

In his conclusion, Sánchez states that:

[...] [his] purpose is to establish [...] a kind of scientific knowledge that is both sound and as easy as possible to attain; but not a science that is full of those chimeras and fictions, unconnected with factual truth, which are put together, not to teach facts, but solely to show off the writer's intellectual subtlety. ${ }^{129}$

He concludes the treatise by writing: "In the meantime, as I prepare to examine Things, I shall raise the question whether anything is known, and if so, how, in the introductory passages of another book, a book in which I will expound, as far as human frailty allows, the method of knowing." 130 Sánchez states several times throughout the treatise that it is his goal to 'establish a science as firm and simple as possible' and to compose a 'method of knowledge,' - in other

128 Regarding this, see, e.g.: "Cognitio omnis a sensu trahitur. Ultra hanc, omnia confusio, dubitatio, perplexitas, divinatio: nil certum. Sensus solum exteriora videt: nec cognoscit" (p. 130)/“All understanding is derived from the senses, and beyond this kind of understanding, all is confusion, doubt, perplexity, guesswork; nothing is certain” (p. 236); “Certissima cognitio a sensu. Incertissima a ratione" [The most certain knowledge comes from the senses, the most uncertain from reason] (marginalia); "Nil certius sensu: nil eodem fallacius” (p. 140)/ "[N]othing is more reliable, or again more deceptive, than the senses" (p. 252); pp. 157-163/pp. 277-289 (for the central quote [p. 157; p. 277], see below note 131); "Experimentum sine iudicio stare nequit" [Experience can not exist without judgment] (marginalia); “[...] quot experimenta habere potest iuuenis? Sat pauca. Quomodo ergo super pauca recte iudicium ferat?" (p. 157)/“[. . ] how many experiences can a mere youth command? Few enough. How, then, is he to judge aright on the basis of only a few?” (p. 278; italics in the original); "Proinde \& maior literatorum numerus his temporibus fidelis quidem est, non sciens: quippe qui ex libris quidquid habent hauriant, non adhibito iudico, rerumque experimento, ut decet [. . .]" (p. 159)/“For just this reason, the majority of educated men in our day are indeed characterised by belief, not knowledge, insofar as they derive all they possess from books. They do not apply judgment and an experimental grasp of facts, as they should [...]" (p. 282). Limbrick puts this aspect as follows: "Sanches's scepticism is philosophically anchored in the Academic scepticism of the school of Carneades and confirmed by his own experiences as a physician who adhered to the Galenic method with its insistence on judgement and empirical observation" ("Introduction" [cf. note 97], p. 88; see, furthermore, esp. pp. 54 f.).

129 P. 290; italics in the original. "Mihi namque in animo est firmam, \& facilem quantum possim scientiam fundare: nin vero chimaeris \& fictionibus a rei veritate alienis, quaeque ad ostendendam solum scibentis ingenij subtilitatem, non ad docendas res comparatae sunt, plenam" (pp. 163 f.).

130 P. 290; italics in the original. "Interim nos ad res examinandas accingentes, an aliquid sciatur, \& quomodo, libello alio praeponemus: quo methodum sciendi, quantum fragilitas humana patitur, exponemus” (p. 164). 
words a treatise dedicated to 'scientific method' (De methodo sciendi) based on 'experience' and 'judgement.' 131 This, as well as the tendency towards empiricism identified in his work, has led him be considered a precursor of empiricism. There are also those who have interpreted his doubt as 'methodical' in the sense that his skeptical criticism of existing knowledge merely serves to create a new basis of certainty, and thus corresponds in principle to Cartesian doubt. ${ }^{132}$ Whether or not Sánchez ever wrote this treatise on scientific method we do not know. Certainly, no such treatise has survived, nor is any mention of it made in the literature of the period. The question of whether something can be known with certainty is left open at the end of the text and thus a claim to absoluteness of the proposition 'nihil scitur' is relativized. After examining the 'things' (res), he would discuss 'whether something is known and how' ('[...] nos ad res examinandas accingentes, an aliquid sciatur, et quomodo, libello alio

131 See: "Duo sunt inueniendae veritatis media miseris humanis: quādoquidem res per se scire non possunt, quas si intelligere, ut deberent, possent, nullos alio indigerent medio: sed cum hoc nequeant, adiumenta ignorantiae sua adinvenere: quibus propterea nil magis sciunt, perfecte saltem. Seda liquid percipiunt, discuntque. Ea vero sunt experimentum, iudicumque. Quodrum neutrum sine alio stare recte potest: quorumque utrumque quomodo habendum, adhibendumque sit, in libello huic proximo, quem indies parturimus, latius declarabimus. Interim vede ex hoc Nihil sciri” (p. 157)/“For luckless humanity, there are two means of discovering truth, since men cannot know things in themselves. If they could acquire intellectual understanding of them as they should be able to do, then they would need no other means; but since they cannot do this, they have found additional ways of coming to the aid of their own ignorance. Consequently, although they have no more knowledge because of these aids (at least in the sense of perfect knowledge) yet they do perceive something, and learn something. Those methods consist of experience and judgment. Neither of these two can properly retain validity without the other. I shall explain at greater length how each of them is to be acquired, and how applied, in my next treatise after this one (I am daily bringing it to birth). For the present, abserve how it follows, from the following consideration, that "nothing is known"” (p. 278; italics in the original); as well as the marginalias: "De modo sciendi librum expecta" [Expect a book On the method of knowledge] and "In libro, Modi sciendi, docebitur quomodo quid discutiatur sine syllogistica doctrina" [In the book On the method of knowledge I will teach how something is discussed without the science of the syllogists].

132 See, e.g., Bullón, Los precursores de Bacon y Descartes (cf. note 97), pp. 160-188 ("Podemos, por lo tanto, afirmar que si la labor filosófica de Francisco Sánchez empieza pareciéndose a la de Descartes, termina por ser semejante a la de Bacon de Verulam” [p. 186]); Popkin, The History of Scepticism (cf. note 1), p. 41 (“[...] Sanches put forward a procedure, not to gain knowledge but to deal constructively with human experience. This procedure, for which Sanches introduced the term (for the first time) scientific method, 'Método universal de las ciencias', consists in patient, careful empirical research and cautious judgement and evaluation of the data we observe.”); Howald, "Einleitung” (cf. note 97), pp. LVII-LXXII, who provides an overview of the two interpretive lines ('constructive interpretation' and 'skeptical interpretation') of the Sanchezian doubt. 
praeponemus: quo methodum sciendi [...]'), the answer to the first question serving as a prerequisite for the exploration of the second. ${ }^{133}$ Remarkably, Sánchez concludes Quod nihil scitur with the word “QUID?” [What?]. ${ }^{134}$ The question implies openness, room for counterargument, a continuation of the conversation, a lack of closure and persistence of doubt, an open-ended search for an answer to the question of whether knowledge is possible or not. In this respect,

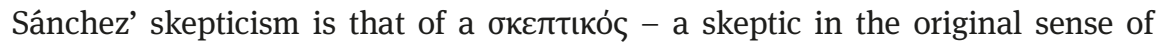
a seeking, questioning, examining, inquiring person. ${ }^{135}$

\subsubsection{René Descartes and Skeptical Philosophy}

In comparison to the previously discussed texts, René Descartes' (1596-1650) engagement with skepticism is situated in a changed discursive context. Called the father of modern philosophy by Schopenhauer, ${ }^{136}$ Descartes, a mathematician

133 See also: "You have, then, observed the difficulties that place scientific knowledge beyond our reach. I am aware that perhaps much of what I have said will not find favour; but on the other hand, you will say, neither have I demonstrated that nothing is known. At least, I have expounded my own opinion as clearly, accurately, and truthfully as I could [...]" (Sánchez, That Nothing is Known [Quod nihil scitur] [cf. note 99], p. 289; my italics) ("Ergo vidisti difficultates quae scientiam nobis adimunt. Scio, plura forsam non placebunt ex his quae hic dixi: sed nec, dices, demonstraui nil scire. Saltem quantum potui clare, fideliter, \& vere, quid sentirem exposui” [p. 163; my italics]).

134 P. 164; p. 290.

135 Cf. once more Sextus Empiricus' distinction between the philosophical schools at the beginning of his Outlines: "The natural result of any investigation is that the investigators either discover the object of search or deny that it is discoverable and confess it to be inapprehensible or persist in their search. So, too, with regard to the objects investigated by philosophy, this is probably why some have claimed to have discovered the truth, others have asserted that it cannot be apprehended, while others again go on inquiring. Those who believe they have discovered it are the 'Dogmatists,' specially so called-Aristotle, for example, and Epicurus and the Stoics and certain others; Cleitomachus and Carneades and other Academics treat it as inapprehensible: the Sceptics keep on searching" (Sextus Empiricus, Pyrr. Hyp. I, 1-3 [S. E., Outlines (cf. note 6), p. 2/3; my italics]); see also Diogenes Laertius, Vitae et sententiae philosophorum IX, 11(69) (Diogenes Laertius, Lives of Eminent Philosophers [cf. note 4], p. 183). Limbrick ("Introduction" [cf. note 97], p. 3) and Howald ("Einleitung” [cf. note 97], p. CLVIII), too, point to this aspect, despite differences in the interpretation of Sánchez' skepticism.

136 As already in his dissertation Über die vierfache Wurzel des Satzes vom zureichenden Grunde (1813): “[. . .] unser[n] vortreffliche[r] Kartesius, [. . . Vater der neuern [sic] Philosophie [...]" (Arthur Schopenhauer, Ueber die vierfache Wurzel des Satzes vom zureichenden Grunde: Eine philosophische Abhandlung, ed. Julius Frauenstädt, 4th ed., Leipzig 1875 [1st ed. 1813], p. 9); see also Schopenhauer, “Skizze einer Geschichte der Lehre vom Idealen und Realen,” in: 
and philosopher, was active during a time when political, social, economic, and ideological conflicts were intensifying throughout Europe. The bloody Thirty Years' War (1618-1648) that engulfed much of central Europe represents a farreaching escalation in this period of crisis. It ended up transforming the political face of Europe and testifies the insoluble hardening of the battle lines that had begun to be drawn with the Reformation. It came on the heels of the French Wars of Religion (1562-1598) that took place between Catholics and Protestant Huguenots and claimed the lives of an estimated three million people in France. This conflict officially ended in 1598 when, sixteen years after the so-called St. Bartholomew's Day Massacre, Henry of Navarre, the first Bourbon to rise to the French throne in 1594, had (once again) converted to Catholicism to become King Henry IV of France and issued the Edict of Nantes. The edict confirmed Catholicism as a state religion, but granted subjects freedom of conscience. Calvinist Protestants were granted civil and political equality, and were allowed to practice their religion within specific territories. ${ }^{137}$ King Henry IV was assassinated in 1610, an indication of the changing political, ideological, and intellectual climate in Europe and France in particular. ${ }^{138}$ With his death the freedoms

Schopenhauer, Parerga und Paralipomena: Kleinere philosophische Schriften, 2 vols., Berlin 1851, vol. 1, pp. 1-27, here p. 3, passim. It should be added more precisely that Descartes primarily next to Francis Bacon - is of course regarded as 'one' of the pioneers of modern philosophy and science.

137 Protestants were forbidden to worship openly at court, or in Paris and the surrounding area (cf. Art. 13 and Art. 14 of the Edict); the places of refuge and security given to them (for eight years they maintained military garrisons that were financially subsidised by the Crown) were primarily in the Protestant south and southwest of the kingdom (cf. the second addition to the Edict, 'Brevet des garnisons': “Aujourd'huy dernier jour d'avril 1598, le roy etant à Nantes, voulant donner tout le contentement qu'il luy est possible à ses sujets de la Religion pretendue reformée sur les demandes et requestes qui luy ont esté faites de leur part pour ce qu'ils ont estimé leur estre necessaire, tant pour la liberté de leurs consciences que pour l'asseurance de leurs personnes, fortunes et biens, et pour l'asseurance que Sa Majesté a de leur fidelité et sincere affection à son service, [. . . ] leur a accordé et promis: Que toutes les places, villes et chasteaux qu'ils tenoient jusques à la fin du mois d'aoust dernier, esquelles y aura garnisons, par l'estat qui en sera dressé et signé par Sa Majesté, demeureront en leur garde sous l'authorité et obeïssance de Sa[dite] Majesté par l'espace de huict ans à compter du jour de la publication du[dit] edict. [...] Et pour l'entretenement des garnisons qui devront estre entretenues e[n lesdites] villes, places et chasteaux, leur a Sa[dite] Majesté accordé jusques à la somme de neuf-vingts mille escus [...]”; important cities were, for instance, La Rochelle, Cognac, Saumur, Montpellier, Nîmes) (Consulted edition: Bernard Barbiche [ed.], L'Édit de Nantes et ses antécédents (1562-1598), Paris n.d. [critical online edition], URL: http://elec.enc. sorbonne.fr/editsdepacification/ [retrieved: 28 March 2019]).

138 Stephen E. Toulmin, Cosmopolis: The Hidden Agenda of Modernity, Chicago 1992 (1st ed. New York 1990), pp. 45-56 (cf. “To suggest that this event [the assassination of King Henry IV 
granted to the Huguenots were increasingly eroded, particularly under the leadership of Cardinals Richelieu and Mazarin ${ }^{139}$ during the reign of Louis XIII and his son Louis XIV. The situation continued to deteriorate until in 1685, Louis XIV issued the Edict of Fontainebleau that revoked the Edict of Nantes and banned Protestantism in France, leading to the emigration of the majority of Huguenots to England, Prussia, and Holland. In France, the religious conflict was, from the beginning, strongly mixed with political motivations. The principle of cuius regio, eius religio [Whose realm, his religion] established at the Peace of Augsburg in 1555 could not be applied to the large, contiguous territory of the French kingdom. Henry IV's policy of seeking to stabilize 'national' unity, ${ }^{140}$ which formed one of the foundations of the state absolutism that was consolidating itself among its successors, was integrative; for the first time, it conceded a separation between loyalty to a sovereign and religious affiliation. ${ }^{141}$ "In practical terms," says Toulmin, who also sees a resemblance between Henry's political approach and Montaigne's intellectual approach, ${ }^{142}$ "the murder of King Henry IV carried

of France] caused the shift from humanism to more rigorous, dogmatic modes of thought would be an exaggeration: it will be enough to see it as emblematic of changes that were ready to begin or had already begun. Henry's murder may or may not have been 'epoch-making'; but, at least, we can take it as 'epoch-marking'” [p. 46; italics in the original]). Already before the murder perpetrated by François Ravaillac on 14 May 1610, a fanatical supporter of the Catholic League, there had been assassination attempts against the king (the predecessor to the throne Henry III had also been murdered in 1589): In 1594 this led to an expulsion of the Jesuits from parts of the country decided by the Paris Parliament, since the assassin was a member of the order, which, however, was annulled again in 1603 by a decree of Henry IV (see p. 48 and p. 52).

139 Cf. p. 51. To be mentioned by way of example are the siege and fall of the Huguenot main base La Rochelle (1627-28) and the so-called Edict of Grace of Nîmes, issued in 1629 by Louis XIII, which decreed the military and political disempowerment of the Protestants but (still) confirmed the right to exercise religion in accordance with the Edict of Nantes (see Janine Garrisson, L'Édit de Nantes et sa révocation: Histoire d'une intolérance, Paris 1985, pp. 65-80). 140 The foreign policy situation was also fragile: the conflict with Spain continued to pose a threat to the French kingdom, which in principle was not resolved until the Pyrenean Peace of 1659 and their final takeover of hegemonic power on the continent.

141 Toulmin points out, on the one hand, that also in Poland Protestants had initially been guaranteed religious tolerance (Cosmopolis [cf. note 138], p. 51), but in the course of the Counter-Reformation the constitutionally anchored religious freedom was abolished in the 1630s (p. 53). On the other hand, he emphasizes again the exceptional status of the politics attempted in France by referring to the situation in England, more precisely: the persecution of the Protestants under Queen Mary I (r. 1553-1558) respectively of the Catholics under Elizabeth I (r. 1558-1603) (p. 51).

142 P. 50 (cf.: "Henry IV's relaxed attitude to practical politics reminds one of Michel de Montaigne's attitude in the intellectual realm."). 
to people in France and Europe the simple message, 'A policy of religious toleration was tried, and failed.' For the next forty years, in all the major powers of Europe, the tide flowed the other way." 143

The first decades of the 17th century were also rocked by the acceptance of the heliocentric world view as a result of Galileo Galilei's (1564-1641) proof of the Copernican hypotheses and the findings of Johannes Kepler (1571-1630). ${ }^{144}$

As a result of these political, religious, and scientific upheavals, the skepticism of the 16th century and the openness and plurality that characterized Renaissance discourse were followed, in the 17th century, by an increasingly urgent need for certainty and a discursive change and the rejection of the answers provided by Pyrrhonian skepticism. ${ }^{145}$ For this period, shaken by one crisis after another, the 'answers' of skepticism, a Pyrrhonian attitude seemed more and more "unacceptable." ${ }^{146}$ As Popkin states, in the first half of the 17th century,

The Reformation had produced a crise pyrrhonienne in religious knowledge in the quest for absolute assurance about religious truths. [...] As the scientific reformation began, and the system of Aristotle was challenged, the sceptical attack quickly broadened the problem to an assault on the basis of all knowledge. [...] The "new science" of Copernicus, Kepler, Galileo, and Gassendi has "cast all in doubt." The discoveries in the New World and in the classical world had given other grounds for scepticism. The cumulative attacks of humanistic Pyrrhonists[,] [...] [like] Montaigne [...], and of scientific Pyrrhonists like Gassendi [...], left the quest for guaranteed knowledge about the "real" world without a method, a criterion, or basis. No type of rational inquiry into the truth of things seemed possible [...]. The crise pyrrhonienne had overwhelmed man's quest for certainty in both religious and scientific knowledge. [...] In this critical situation, the scientists, the philosophers, and the theologians would either have to fight for survival or

143 P. 53. According to Toulmin, the only remaining "haven of tolerance" were the Netherlands (ibid.).

144 The discovery of the telescope dates from 1609, in 1610/11, Galileo's relevant astronomical discoveries follow, in 1632, the Dialogo on the two world systems is published, in 1636 the Discorsi; the so-called Kepler's Laws of planetary motion are formulated in the years 1609 and 1619.

145 Significantly, in Popkin's study, the chapter opening this complex of discussion is titled "The Counterattack Begins" (The History of Scepticism [cf. note 1], pp. 99-110 [see also the following quote above]); Toulmin calls the first half of the 17th century "Counter-Renaissance" (Cosmopolis [cf. note 138], pp. 45-87).

146 Cf. p. 55: "By 1620, people in positions of political power and theological authority in Europe no longer saw Montaigne's pluralism as a viable intellectual option, any more than Henri's tolerance was for them a practical option. The humanists' readiness to live with uncertainty, ambiguity and differences of opinion had done nothing (in their view) to prevent religious conflict from getting out of hand: ergo (they inferred) it had helped cause the worsening state of affairs. If skepticism let one down, certainty was more urgent. It might not be obvious what one was supposed to be certain about, but uncertainty had become unacceptable." 
abandon the quest for certainty. Gradually, first in the area of religion and then in science and philosophy, the menace of Pyrrhonism was recognized, and a counterattack was begun. ${ }^{147}$

When Descartes published his first work, the Discours de la méthode pour bien conduire sa raison et chercher la vérité dans les sciences [Discourse on the Method of Rightly Conducting One's Reason and Seeking the Truth in the Sciences], ${ }^{148}$ anonymously in Leiden (he arrived in the Netherlands in 1629), an anti-skepticist reaction was in ascendance and Montaigne's playful, open form of skepticism was no longer possible. Descartes' exploration of skepticism was aimed at overcoming the ever-intensifying 'quest for certainty.' It was his intention to create a firm basis of knowledge, a solid philosophical foundation on which all other sciences could be built.

Before looking at the text that is central to this, the Meditationes de prima philosophia [Meditations on First Philosophy], first published in $1641,{ }^{149}$ I will first refer to a discussion on the foundations of metaphysics that appears in the

147 Popkin, The History of Scepticism (cf. note 1), pp. 97 ff. See also Toulmin: "If Europeans were to avoid falling into a skeptical morass, they had, it seemed, to find something to be "certain' about. [...] On reflection, perhaps, human experience might turn out to embody clarities and certainties that Montaigne and the skeptics had overlooked. Henry's murder was not an immediate occasion to renew the philosophical dialogue, but it helped to bring the desperation of the time into sharper focus, and provided a natural context in which the Quest for Certainty could take shape.” (Cosmopolis [cf. note 138], pp. 55 f.; italics in the original).

148 - followed by the three treatises, 'essays with this method' (Essais de cette méthode): La Dioptrique, Les Météors, and La Géometrie (the subtitle of the first edition reads further: Plus La Dioptrique, Les Météors, et La Géometrie. Qui sont des essais de cette Méthode [and in addition the Optics, the Meteorology and Geometry, which are essays in this Method]).

149 Descartes' Meditations on First Philosophy were published in Paris in 1641 under the full title Meditationes de Prima Philosophia, in qua Dei existentia et animae immortalitas demonstratur [Meditations on First Philosophy in which are demonstrated the existence of God and the distinction between the human soul and the body], together with the first six 'Objectiones et Responsiones,' the 'objections' formulated by, among others, Thomas Hobbes (1588-1679) and Pierre Gassendi (1592-1655) and Descartes' respective 'replies'; the second edition, published in Amsterdam in 1642, was extended by another series of 'Objections' and 'Replies' (Meditationes de Prima Philosophia, in quibus Dei existentia, et animae humanae a corpore distinctio, demonstrantur. His adjunctae sunt variae objectiones doctorum virorum in istas de Deo et anima demonstrationes; cum Responsionibus Authoris. Secunda editio septimis objectionibus antehac non visis aucta); in 1647, for the first time a French translation of the texts was published (Les Méditations Métaphysiques). Also relevant is the first part ('De principiis cognitionis humanae'/'About the principles of human knowledge') of the Principia philosophiae [Principles of Philosophy] published in 1644 (in: Descartes, E Euvres [cf. note 100], vol. 8,1 [1905], here pp. 5-39; The Philosophical Writings of Descartes [cf. note 100], vol. 1, pp. 177-291, here pp. 193-222). 
fourth part of the Discours. ${ }^{150}$ This text provides an outline of what Descartes goes on to elaborate in great detail in the Meditationes, and as such can be understood as a kind of prologue to the later work. ${ }^{151}$ The text begins:

[...] [A]lors je désirais vaquer seulement à la recherche de la vérité, je pensai qu'il fallait [...] que je rejetasse, comme absolument faux, tout ce en quoi je pourrais imaginer le moindre doute afin de voir s'il ne resterait point, après cela, quelque chose en ma créance, qui fût entièrement indubitable. ${ }^{152}$

'[...] I now wished to devote myself solely to the search for truth, I thought it necessary to do the very opposite and reject as if absolutely false everything in which I could imagine the least doubt, in order to see if I was left believing anything that was entirely indubitable., ${ }^{, 153}$

The way to achieve the goal of a 'entirely indubitable' knowledge base (qui fût entièrement indubitable) requires the rejection as false of all that can be called into doubt. More precisely, that for which only the slightest doubt could be 'imagined' (en quoi je pourrais imaginer le moindre doute). The reference to the dream argument (which will be explained later in more detail) is then formulated as follows:

Et enfin, considérant que toutes les mêmes pensées, que nous avons étant éveillés, nous peuvent aussi venir, quand nous dormons, sans qu'il y en ait aucune, pour lors, qui soit vraie, je me résolus de feindre que toutes les choses qui m'étaient jamais entrées en l'esprit n'étaient non plus vraies que les illusions de mes songes. ${ }^{154}$

'Lastly, considering that the very thoughts we have while awake may also occur while we sleep without any of them being at the that time true, I resolved to pretend [to feign/for the fiction] that all the things that had ever entered my mind were no more true than the illusions of my dreams. ${ }^{, 155}$

150 This is what it says in Descartes' summary of content, preceding Discours: "En la $4^{\mathrm{e}}$ [partie], [on trouvera] les raisons par lesquelles il [l'auteur] prouve l'existence de Dieu et de l'âme humaine, qui sont les fondements de sa métaphysique" (Descartes, Discours de la méthode [cf. note 100], p. 1)/'In the fourth [discourse] [you will find] the arguments by which he proves the existence of God and the human soul, which are the foundations of his metaphysics' (Descartes, Discourse on the Method [cf. note 100], p. 111).

151 Cf. Christian Wohlers, "Vision und Illusion des Neuanfangs," in: René Descartes, Meditationes de prima philosophia [Latin-German], ed. and trans. Christian Wohlers, Hamburg 2008, pp. VII-XLIX, here pp. XIII f.

152 Descartes, Discours de la méthode IV (cf. note 100), p. 31, my italics.

153 Descartes, Discourse on the Method (cf. note 100), pp. 126 f., my italics.

154 Descartes, Discours de la méthode IV, 1 (cf. note 100) p. 32; my italics.

155 Descartes, Discourse on the Method (cf. note 100), p. 127; my italics. 
The constructed exaggeration, the artificiality of the argument, are revealed by the use of the verb feindre ('to pretend/to feign'). This highlights clearly that Descartes' 'search for truth' primarily makes use of the tools of rhetoric (rather than of logic). In the continuation of the passage above, Descartes begins to formulate his concept of certainty, which is central to his thinking, as well as explicitly stating the relation of skepticism, and its quasi rhetorical instrumentalization, to his epistemological project:

Mais, aussitôt après, je pris garde que, pendant que je voulais ainsi penser que tout était faux, il fallait nécessairement que moi, qui le pensais, fusse quelque chose. Et remarquant que cette vérité: je pense, donc je suis, était si ferme et si assurée, que toutes les plus extravagantes suppositions des sceptiques n'étaient pas capables de l'ébranler, je jugeai que je pouvais la recevoir, sans scrupule, pour le premier principe de la philosophie que je cherchais. ${ }^{156}$

'But immediately I noticed that while I was trying thus to think everything false, it was necessary that I, who was thinking this, was something. And observing that this truth 'I am thinking, therefore I exist' was so firm and sure that all the most extravagant suppositions of the sceptics were incapable of shaking it, I decided that I could accept it without scruple as the first principle of the philosophy I was seeking. ${ }^{, 157}$

Elsewhere in the text Descartes distances himself from the skeptics and makes a distinction between skeptical and methodical doubt. He was not imitating the skeptics, he claims, for they doubted solely in order to doubt and gladly gave the impression that they were always indecisive; his intention, however, was to achieve certainty and 'to cast aside the loose earth and sand so as to come upon rock or clay.' In other words, Descartes saw doubt as a means to achieve his goal of irrefutable certainty:

Non que j'imitasse [...] les sceptiques, qui ne doutent que pour douter, et affectent d'être toujours irrésolus: car, au contraire, tout mon dessein ne tendait qu'à m'assurer, et à rejeter la terre mouvante et le sable, pour trouver le roc ou l'argile. ${ }^{158}$

156 Descartes, Discours de la méthode IV, 1 (cf. note 100) p. 33 (italics in the original ['je pense, donc je suis'] and my italics).

157 Descartes, Discourse on the Method (cf. note 100), p. 127 (italics in the original ['I am thinking, therefore I exist'] and my italics).

158 Descartes, Discours de la méthode III, 6, p. 29 (In context: "Et en toutes les neuf années suivantes, je ne fis autre chose que rouler çà et là dans le monde, tâchant d'y être spectateur plutôt qu'acteur en toutes les comédies qui s’y jouent; et faisant particulièrement réflexion, en chaque matière, sur ce qui la pouvait rendre suspecte, et nous donner occasion de nous méprendre, je déracinais cependant de mon esprit toutes les erreurs qui s'y étaient pu glisser auparavant. Non que j'imitasse pour cela les sceptiques, qui ne doutent que pour douter, et affectent d'être toujours irrésolus: car, au contraire, tout mon dessein ne tendait 
'[. . . I I was not copying the sceptics, who doubt only for the sake of doubting and pretend to be always undecided; on the contrary, my whole aim was to reach certainty - to cast aside the loose earth and sand so as to come upon rock or clay. ${ }^{159}$

In the Meditationes there are also instances of a decidedly anti-Pyrrhonian attitude. For example, in his 'Reply' to the 'Fifth Set of Objections' elaborated by Pierre Gassendi (Responsio authoris ad quintas objectiones), ${ }^{160}$ when responding to objections raised regarding doubt over the reliability of sensory perception in the second Meditatio Descartes emphasizes the separation between theory and practice. One must strictly distinguish between the "inquisitione[s] veritatis" ("investigation of the truth") and the "actiones vitae" ("actions of life"). Absolute doubt should not be transferred to the "[vita] regenda" ("way of living'), and his judgement about the skeptics is accordingly mocking:

When I said that the entire testimony of the senses should be regarded as uncertain and even as false, I was quite serious; indeed this point is so necessary for an understanding of my Meditations that if anyone is unwilling or unable to accept it, he will be incapable of producing any objection that deserves a reply. However, we must note the distinction which I have insisted on in several passages, between the actions of life and the investigation of the truth. For when it is a question of organizing our life, it would, of course, be foolish not to trust the senses, and the sceptics who neglected human affairs to the point where friends had to stop them falling off precipices deserved to be laughed at. Hence I pointed out in one passage that no sane person ever seriously doubts such things. ${ }^{161}$

qu'à m'assurer, et à rejeter la terre mouvante et le sable, pour trouver le roc ou l'argile. Ce qui me réussissait, ce me semble, assez bien, d'autant que, tâchant à découvrir la fausseté ou l'incertitude des propositions que j'examinais, non par de faibles conjectures, mais par des raisonnements clairs et assurés, je n'en rencontrais point de si douteuses, que je n'en tirasse toujours quelque conclusion assez certaine, quand ce n'eût été que cela même qu'elle ne contenait rien de certain” [pp. 28 f.]/“Throughout the following nine years I did nothing but roam about in the world, trying to be a spectator rarher than an actor in all the comedies that are played out there. Reflecting especially upon the points in every subject which might make it suspect and give occasion for us to make mistakes, I kept uprooting from my mind any errors that might previously have slipped into it. In doing this I was not copying the sceptics, who doubt only for the sake of doubting and pretend to be always undecided; on the contrary, my whole aim was to reach certainty - to cast aside the loose earth and sand so as to come upon rock or clay. In this I think I was quite successful. For I tried to expose the falsity or unerrtainty of the propositions I was examining by clear and certain arguments, not by weak conjectures; and I never encountered any proposition so doubtful that I could not draw from it some quite certain conclusion, if only the conclusion that it contained nothing certain' [Descartes, Discourse on the Method, p. 125]).

159 Descartes, Discourse on the Method, p. 125.

160 For the Objectiones et Responsiones, see above note 149.

161 René Descartes, Meditations on First Philosophy, in: The Philosophical Writings of Descartes (cf. note 100), vol. 2, p. 243 (Author's Replies to the Fifth Set of Objections, 
The starting point of Descartes' Meditations on First Philosophy is a “[...] general demolition of [all] my opinions [.. .] to demolish everything completely and start again right from the foundations [...] [in order] to establish [some]thing [...] in the sciences that was stable and likely to last.” The I of the Meditationes continues: "[...] [F]or the purpose of rejecting all my opinions [...] it will be enough if I find in each of them at least some reason for doubt."162 Radical doubt is not propagated as a goal, but as a method by which to arrive at a solid basis of knowledge. It is a pursuit whose goal is not to establish isosthenias that can lead to epoché and ultimately to an indifferent serenity perceived as happiness, but to pave the way to assured certainty. Descartes opposes the idea that truth is impossible to recognize by striving for the creation of unquestionable truths.

When orchestrating radical methodical doubt as preparation for the acceptance of the basis of certainty of the cogito, ergo sum, Descartes attributes particular significance to the skeptical dream argument. ${ }^{163}$ In Sextus Empiricus'

pp. 241-267). "Quod enim dixi, 'omnia sensuum testimonia pro incertis, imo etiam pro falsis, esse habenda', omnino serium est, \& ad meas Meditationes intelligendas adeo necessarium, ut quisquis illud admittere non vult, aut non potest, nihil in ipsas responsione dignum objiciendi sit capax. Sed advertenda est distinctio, variis in locis a me inculcata, inter actiones vitae \& inquisitionem veritatis. cùm enim de regendâ vitâ quaestio est, ineptum sane esset sensibus non credere, planeque ridendi fuerunt illi Sceptici qui res humanas eò usque negligebant, ut, ne se in praecipitia conjicerent, ab amicis deberent asservari; atque idcirco alicubi admonui, 'neminem sanae mentis de talibus seriò dubitare"' (René Descartes, Meditationes de prima philosophia, in: Descartes, Euvres [cf. note 100], vol. 7 [1904]: Meditationes de prima philosophia, pp. 350 f. [Responsio Authoris ad Quintas Objectiones, pp. 347-391]); see also Descartes, Euvres, vol. 7, p. 460 ('the metaphysical, hyperbolic doubt can not be transferred to practical life': "[...] de summâ illâ dubitatione, quam saepe metaphysicam, hyperbolicam, atque ad usum vitae nullo modo transferendam esse [...]” ['Objectiones Septimae cum notis authoris']; regarding the mentioned anecdote, see Diogenes Laertius, Vitae philosophorum IX,62 (Lives of Eminent Philosophers [cf. note 4], pp. 457 ff.).

162 Descartes, Meditations (cf. note 161), First Meditation 'What can be called into doubt,' p. 12; “[ . . ] ac proinde funditus omnia semel in vita esse evertenda, atque a primis fundamentis denuo inchoandum, si quid aliquando firmum \& mansurum cupiam in scientiis stabilire; [...] solus secedo, serio tandem \& libere generali huic mearum opinionum eversioni vacabo. [...] sed quia jam ratio persuadet, non minus accurate ab iis quae non plane certa sunt atque indubitata, quam ab aperte falsis assensionem esse cohibendam, satis erit ad omnes rejiciendas, si aliquam rationem dubitandi in unaquaque reperero" (Descartes, Meditationes [cf. note 161], Meditatio I 'De iis quae in dubium revocari possunt,' pp. $17 \mathrm{f}$.).

163 It should be noted that though the corresponding line of argument is (see Meditatio II), the prominent formulation, however, is not to be found in the Meditationes (there it reads: 'ego sum, ego existo; certum est' and 'res cogitans [sum]' [see below]). The central passage from the Discours de la méthode ('je pense, donc je suis') has already been quoted (see above, 


\section{Outlines of Pyrrhonism, the fourth of the ten 'tropes of suspension of judgement' attributed to Aenesidemus relativizes the possibility of obtaining reliable}

notes 156 and 157); see, furthermore, Principia philosophiae I, 7 and I, 10 (Descartes, Principia philosophiae [cf. note 149], p. 7 and p. 8; Descartes, Principles of Philosophy [cf. note 149], pp. 194 f. and pp. 195 f.). The aspect extensively discussed in research of the "historical precursors' of the Cartesian formula of certainty (cf. the related remarks in Wohlers, "Vision und Illusion des Neuanfangs" [cf. note 151], p. XXXIII) can only be mentioned here. Worth mentioning in this context (without going into the differences with regard to statement, context and intention of the argumentation) is the Augustinian Si fallor, sum [If I am mistaken, I am] - the doubt itself cannot be doubted; it reflects the recognition of one's own being). On the one hand, Descartes himself points to the source in a letter to Marin Mersenne (1588-1648): "Vous m'auiez cy-deuant auerty d'vn passage de S. Augustin, touchant mon Je pense, donc je suis, que vous m'auez, ce me semble, redemandé depuis; il est au Liure onzième de Ciuitate Dei, chap. 26" (Lettre CCXXII: Descartes à Mersenne [Leyde, décembre 1640], in: Descartes, Euvres [cf. note 100], vol. 3 [1899]: Correspondance III, janvier 1640 à juin 1642, pp. 253-262, here p. 261)/'Some time ago, you drew my attention to a passage from St Augustine concerning my I am thinking therefore I exist, and I think you have asked me about it again since then. It is in Book Eleven, chapter 26 of De Civitate Dei' (The Philosophical Writings of Descartes [cf. note 100], vol. 3: The Correspondence, p. 161). On the other hand, in Augustine, who as is known also deals with skepticism elsewhere, especially in his early work Contra Academicos, the argument is explicitly directed against the (however: Academic) skeptics: "Nulla in his veris [mihi esse me, idque nosse et amare certissimum est] Academicorum argumenta formido dicentium: Quid, si falleris? Si enim fallor, sum. Nam qui non est, utique nec falli potest; ac per hoc sum, si fallor" [In these truths (that I am, that I know this, and that I love it), I am not afraid of any objection from the Academics who ask, What if you are wrong? For even if I am wrong, I am. Anyone who is not, cannot be mistaken either, and that is why I am, if I am mistaken] (Aurelius Augustinus, De civitate Dei XI, 26; quoted from: Sancti Aurelii Augustini episcopi De civitate Dei libri XXII, ed. Bernhard Dombart and Alfons Kalb, 2 vols., Stuttgart/Leipzig 1993, vol. 1, p. 498. See also Augustine, Enchiridion de fide, spe et caritate 7,20; De trinitate XV, 12,21; and above all De trinitate X, 10,14 ['dubito ergo sum']). It can also be read in Thomas Aquinas that in the act of thinking the knowledge of self-existence manifests itself: “[...] [N]ullus potest cogitare se non esse cum assensu: in hoc enim ipso quod cogitat aliquid, percipit se esse" [No one can think with consent that he is not; for by thinking something he realizes that he is] (De veritate q. 10 a. 12 ad. 7; quoted from: Thomas Aquinas, Opera omnia [Editio Leonina], 50 vols. [still unfinished], Rome 1882-, vol. 22,2 [1972]: Quaestiones disputatae de veritate, QQ. 8-20, p. 342). Bullón (Los precursores españoles de Bacon y Descartes [cf. note 97], p. 104), among others, refers to the pre-forms of the cogito, ergo sum in Augustine and Thomas Aquinas and the passages cited here; he does this in the context of the discussion of the Antoniana Margarita (1554) by the Spanish physician and philosopher Gómez Pereira (1500-1567) as a precursor of Cartesian philosophy (cf. pp. 90-129), the central (cogito-)sentence there reads: "Nosco me aliquid noscere, \& quicquid noscit est, ergo ego sum" [I know that I know something, and everything that knows is; therefore I am] (Gómez Pereira, De immortalitate animorum Antonionae Margaritae, in: Gómez Pereira, Antoniana Margarita: opus nempe physicis, medicis, ac theologis, non minus utile, quam necessarium, Medina del Campo 1554, cols. 609-832, here col. 760 [cf. Bullón, pp. 102 ff.]). 
knowledge by means of sensory perception on the basis of the variability of the state in which the perceiving subject finds himself, and refers, in this context, to the un-decidability of the states of dream and of wakefulness. ${ }^{164}$ The Meditationes initially question the reliability of sensory perception, which hitherto functioned as a mediator of truth, ${ }^{165}$ but then determines that with the exception of insanity, sensory perception gives reliable evidence of objects in the immediate vicinity and of the things concerning the body. However, Descartes then goes further in his radicalization of doubt, and begins to identify the dream as paradigmatic of the deception of sensory perception:

As if I were not a man who sleeps at night, and regularly has all the same experiences I while asleep as madmen do when awake - indeed sometimes even more improbable ones. How often, asleep at night, am I convinced of just such familiar events - that I am here in my dressing-gown, sitting by the fire - when in fact I am lying undressed in bed! Yet at the moment my eyes are certainly wide awake when I look at this piece of paper; I shake my head and it is not asleep; as I stretch out and feel my hand I do so deliberately, and I know what I am doing. All this would not happen with such distinctness to someone asleep. Indeed! As if I did not remember other occasions when I have been tricked by exactly similar thoughts while asleep! As I think about this more carefully, I see plainly that there are never any sure signs by means of which being awake can be

164 Sextus Empiricus, Pyrr. Hyp. I, 100-117 [fourth trope], here I, 104 [dream argument] ("[I, 100:] This is the Mode [the Fourth Mode of suspension] based, as we say, on the 'circumstances,' meaning by 'circumstances' conditions or dispositions. And this Mode, we say, deals with states that are natural or unnatural, with waking or sleeping, with conditions due to age, motion or rest, hatred or love, emptiness or fulness, drunkenness or soberness, predispositions, confidence or fear, grief or joy. [...] [I, 104:] Sleeping and waking, too, give rise to different impressions, since we do not imagine when awake what we imagine in sleep, nor when asleep what we imagine when awake; so that the existence or nonexistence of our impressions is not absolute but relative, being in relation to our sleeping or waking condition. Probably, then, in dreams we see things which to our waking state are unreal, although not wholly unreal; for they exist in our dreams, just as waking realities exist although non-existent in dreams" [Sextus Empiricus, Outlines (cf. note 6), pp. 58/59-68/69, here pp. 60/61-62/63]). It should already be said that precisely this skeptical argument and also the reference to Descartes will play a central role in the context of the discussion of Calderón's drama later in this study (chap. 3.1).

165 "Nempe quidquid hactenus ut maxime verum admisi, vel a sensibus, vel per sensus accepi; hos autem interdum fallere deprehendi, ac prudentiae est nunquam illis plane confidere qui nos vel semel deceperunt” (Descartes, Meditationes [cf. note 161], Meditatio I, p. 18)/ "Whatever I have up till now accepted as most true I have acquired either from the senses or through the senses. But from time to time I have found that the senses deceive, and it is prudent never to trust completely those who have deceived us even once" (Descartes, Meditations [cf. note 161], First Meditation, p. 12). 
distinguished from being asleep. The result is that I begin to feel dazed, and this very feeling only reinforces the notion that I may be asleep. ${ }^{166}$

If dream and wakefulness cannot be distinguished empirically, and if all this is merely a dream, as the thought experiment continues, ${ }^{167}$ nevertheless, simple and universal generalities that shape phenomena (be they true or false) - such as the (Aristotelian) categories - must be undoubtedly true; therefore, in the sciences too, a distinction must be made between unreliable disciplines that depend on the examination of composite things, and the reliable mathematical disciplines: "For whether I am awake or asleep, two and three added together are five, and a square has no more than four sides. It seems impossible that such transparent truths should incur any suspicion of being false." ${ }^{168}$ Building on a "[...] long-standing opinion [...] firmly rooted in my mind [...] that there

166 Descartes, Meditations, First Meditation, p. 13; my italics; “[...] tanquam non sim homo qui soleam noctu dormire, \& eadem omnia in somnis pati, vel etiam interdum minus verisimilia, quam quae [amentes] isti vigilantes. Quam frequenter vero usitata ista, me hic esse, toga vestiri, foco assidere, quies nocturna persuadet, cum tamen positis vestibus jaceo inter strata! Atqui nunc certe vigilantibus oculis intueor hanc chartam, non sopitum est hoc caput quod commoveo, manum istam prudens \& sciens extendo \& sentio; non tam distincta contingerent dormienti. Quasi scilicet non recorder a similibus etiam cogitationibus me alias in somnis fuisse delusum; quae dum cogito attentius, tam plane video nunquam certis indiciis vigiliam a somno posse distingui, ut obstupescam, \& fere hic ipse stupor mihi opinionem somni confirmet” (Descartes, Meditationes, p. 19; my italics).

167 "Age ergo somniemus, nec particularia ista vera sint, nos oculos aperire, caput movere, manus extendere, nec forte etiam nos habere tales manus, nec tale totum corpus" (Descartes, Meditationes, p. 7)/“Suppose then that I am dreaming, and that these particulars - that my eyes are open, that I am moving my head and stretching out my hands - are not true. Perhaps, indeed, I do not even have such hands or such a body at all” (Descartes, Meditations, p. 13).

168 Descartes, Meditations, p. 13. "Nam sive vigilem, sive dormiam, duo \& tria simul juncta sunt quinque, quadratumque non plura habet latera quam quatuor; nec fieri posse videtur ut tam perspicuae veritates in suspicionem falsitatis incurrant” (Descartes, Meditationes, p. 20). For the outlined above, see Descartes, Meditations, pp. 13 f. (cf. Descartes, Meditationes, p. 20: "Nec dispari ratione, quamvis etiam generalia haec, oculi, caput, manus, \& similia, imaginaria esse possent, necessario tamen saltem alia quaedam adhuc magis simplicia \& universalia vera esse fatendum est, ex quibus tanquam coloribus veris omnes istae, seu verae, seu falsae, quae in cogitatione nostra sunt, rerum imagines effinguntur. Cujus generis esse videntur natura corporea in communi, ejusque extensio; item figura rerum extensarum, item quantitas, sive earumdem magnitudo \& numerus; item locus in quo existant, tempusque per quod durent, \& similia. Quapropter ex his forsan non male concludemus Physicam, Astronomiam, Medicinam, disciplinasque alias omnes, quae a rerum compositarum consideratione dependent, dubias quidem esse; atqui Arithmeticam, Geometriam, aliasque ejusmodi, quae nonnisi de simplicissimis \& maxime generalibus rebus tractant, atque utrum eae sint in rerum natura necne, parum curant, aliquid certi atque indubitati continere"). 
is an omnipotent God who made me the kind of creature that I am," doubts about logic and the propositions of mathematics are ultimately also possible, namely in the case that God wanted to cause this deception. But this would be contrary to the benevolence of God, which is assumed. ${ }^{169}$ Even if one espoused the position that there was no almighty God, it would be all the more likely to always be mistaken out of imperfection. ${ }^{170}$ The meditator admits that everything that he had thought to be true so far, all the familiar opinions could ultimately be doubted - and this for well-considered reasons - but stresses that these views are nevertheless so credible that it would be much more reasonable to agree with them and to trust them than to deny them. ${ }^{171}$ In this way, the next

169 "Verumtamen infixa quaedam est meae menti vetus opinio, Deum esse qui potest omnia, \& a quo talis, qualis existo, sum creatus. [...] Imò etiam, quemadmodum judico interdum alios errare circa ea quae se perfectissime scire arbitrantur, ita ego ut fallar quoties duo \& tria simul addo, vel numero quadrati latera, vel si quid aliud facilius fingi potest? At forte noluit Deus ita me decipi, dicitur enim summe bonus; sed si hoc ejus bonitati repugnaret, talem me creasse ut semper fallar, ab eâdem etiam videretur esse alienum permittere ut interdum fallar; quod ultimum tamen non potest dici” (Descartes, Meditationes, p. 21)/“And yet firmly rooted in my mind is the long-standing opinion that there is an omnipotent God who made me the kind of creature that I am. [.. .] What is more, since I sometimes believe that others go astray in cases where they think they have the most perfect knowledge, may I not similarly go wrong every time I add two and three or count the sides of a square, or in some even simpler matter, if that is imaginable? But perhaps God would not have allowed me to be deceived in this way, since he is said to be supremely good. But if it were inconsistent with his goodness to have created me such that I am deceived all the time, it would seem equally foreign to his goodness to allow me to be deceived even occasionally; yet this last assertion cannot be made" (Descartes, Meditations, p. 14). Here are all the concepts that will appear after the establishment of the 'thinking self' as the 'firm foundation of certainty': the precondition of a benevolent God who does not deceive, the primacy of mathematics, and the 'innate ideas' given by God, which enable 'clear and distinct' knowledge.

170 "Essent verò fortasse nonnulli qui tam potentem aliquem Deum mallent negare, quàm res alias omnes credere esse incertas. Sed iis non repugnemus, totumque hoc de Deo demus esse fictitium; [...] quoniam falli \& errare imperfectio quaedam esse videtur, quo minùs potentem originis meae authorem assignabunt, eo probabilius erit me tam imperfectum esse ut semper fallar" (Descartes, Meditationes, p. 21)/“Perhaps there may be some who would prefer to deny the existence of so powerful a God rather than believe that everything else is uncertain. Let us not argue with them, but grant them that everything said about God is a fiction. [...] yet since deception and error seem to be imperfections, the less powerful they make my original cause, the more likely it is that I am so imperfect as to be deceived all the time” (Descartes, Meditations, p. 14).

171 " [...] sed tandem cogor fateri nihil esse ex iis quae olim vera putabam, de quo non liceat dubitare, idque non per inconsiderantiam vel levitatem, sed propter validas \& meditatas rationes; [.. . ] nec unquam iis [consuet(is) opinion(ibus)] assentiri \& confidere desuescam, quamdiu tales esse supponam quales sunt revera, nempe aliquo quidem modo dubias, ut jam jam ostensum est, sed nihilominus valde probabiles, \& quas multo magis rationi consentaneum sit credere quàm negare” (Descartes, Meditationes, pp. 21 f.)/“[ . . ] but [I] am finally compelled to 
step of the strategic-radical doubt, which is intended to establish a firm foundation of knowledge, is initially provided with similar indications as outlined in the abovementioned reference to the Discours: ${ }^{172}$ The constructedness of the argument is made explicit ("[...] non male agam, si, me ipsum fallam, illasque aliquandiu omnino falsas imaginariasque esse fingam [...]”) and the 'riskless' epistemological approach is highlighted ("[...] scio nihil inde periculi vel erroris interim sequuturum, [. . .] quandoquidem nunc non rebus agendis, sed cognoscendis tantum incumbo."). ${ }^{173}$

On the third level of hyperbolic doubt, the indistinguishability between the dream state and the waking state is followed by a hypothesis of an allencompassing deception by a "geniu[s] [...] malignu[s]." Not God, who is the "source of truth" ("fontem veritatis"), but an "evil, most powerful and cunning demon" ("genium [...] malignum, [...] summe potentem \& callidum"), a "deceiver" (“deceptor") who could, with malicious and deceptive intent, ensure that all perceptions and "[...] all external things are merely the delusions of dreams [...]."174

admit that there is not one of my former beliefs about which a doubt may not properly be raised; and this is not a flippant or ill-considered conclusion, but is based on powerful and well thought-out reasons. [...] I shall never get out of the habit of confidently assenting to these opinions, so long as I suppose them to be what in fact they are, namely highly probable opinions - opinions which, despite the fact that they are in a sense doubtful, as has just been shown, it is still much more reasonable to believe than to deny" (Descartes, Meditations, pp. 14 f.).

172 See above pp. $55 \mathrm{f}$.

173 Descartes, Meditationes (cf. note 161), p. 22; my italics (“[. . . I think it will be a good plan to turn my will in completely the opposite direction and deceive myself, by pretending for a time that these former opinions are utterly false and imaginary. I shall do this until the weight of preconceived opinion is counter-balanced and the distorting influence of habit no longer prevents my judgement from perceiving things correctly. In the meantime, I know that no danger or error will result from my plan, and that I cannot possibly go too far in my distrustful attitude. This is because the task now in hand does not involve action but merely the acquisition of knowledge" [Descartes, Meditations (cf. note 161), p. 15; my italics]).

174 "Supponam igitur non optimum Deum, fontem veritatis, sed genium aliquem malignum, eundemque summe potentem, \& callidum, omnem suam industriam in eo posuisse, ut me falleret: putabo coelum, aërem, terram, colores, figuras, sonos, cunctaque externa nihil aliud esse quam ludificationes somniorum, quibus insidias credulitati mea tetendit: considerabo me ipsum tanquam manus non habentem, non oculos, non carnem, non sanguinem, non aliquem sensum, sed haec omnia me habere falso opinantem [...]" (Descartes, Meditationes, pp. 22 f.)/ "I will suppose therefore that not God, who is supremely good and the source of truth, but rather sorne malicious demon of the utmost power and cunning has employed all his energies in order to deceive me. I shall think that the sky, the air, the earth, colours, shapes, sounds and all external things are merely the delusions of dreams which he has devised to ensnare 
The Meditationes do not remain for long in this extreme state of doubt. At its most radical point, the meditator finds the Archimedean point ${ }^{175}$ of all knowledge. All-consuming doubt is finally replaced by the sought-after unquestionable basis of knowledge - the certainty of the existence of the thinking self:

But there is a deceiver of supreme power and cunning who is deliberately and constantly deceiving me. In that case I too undoubtedly exist, if he is deceiving me; and let him deceive me as much as he can, he will never bring it about that I am nothing so long as I think that I am something. So after considering everything very thoroughly, I must finally conclude that this proposition, $I$ am, I exist, is necessarily true whenever it is put forward by me or conceived in my mind. ${ }^{176}$

[...]

Sense-perception? This surely does not occur without a body, and besides, when asleep I have appeared to perceive through the senses many things which I afterwards realized I did not perceive through the senses at all. Thinking? At last I have discovered it thought; this alone is inseparable from me. I am, I exist - that is certain. [. . .] At present I am not admitting anything except what is necessarily true. I am, then, in the strict sense only a thing that thinks; I that is, I am a mind, or intelligence, or intellect, or reason [...]. [...] I am a thing which is real and which truly exists. But what kind of a thing? As I have just said - a thinking thing. ${ }^{177}$

my judgement. I shall consider myself as not having hands or eyes, or flesh, or blood or senses, but as falsely believing that I have all these things" (Descartes, Meditations, p. 15); "deceptor"/“deceiver": ibid. and passim.

175 "Nihil nisi punctum petebat Archimedes, quod esset firmum \& immobile, ut integram terram loco dimoveret; magna quoque speranda sunt, si vel minimum quid invenero quod certum sit \& inconcussum” (Descartes, Meditationes, Meditatio II 'De natura mentis humanae: quod ipsa sit notior quam corpus,' p. 24)/“Archimedes used to demand just one firm and immovable point in order to shift the entire earth; so I too can hope for great things if I manage to find just one thing, however slight, that is certain and unshakeable" (Descartes, Meditations, Second Meditation 'The nature of the human mind, and how it is better known than the body,' p. 16).

176 Descartes, Meditations, p. 17; my italics. "Sed est deceptor nescio quis, summe potens, summe callidus, qui de industria me semper fallit. Haud dubie igitur ego etiam sum, si me fallit; \& fallat quantum potest, nunquam tamen efficiet, ut nihil sim quamdiu mea liquid esse cogitabo. Adeo ut, omnibus satis superuqe pensitatis, denique statuendum sit hoc pronuntiatum, 'Ego sum, ego existo,' quoties a me profertur, vel mente concipitur, necessario esse verum” (Descartes, Meditationes, p. 25; my italics).

177 Descartes, Meditations, p. 18; my italics. "Sentire? nempe etiam hoc non fit sine corpore, et permulta sentire visus sum in somnis, quae deinde animadverti me non sensisse. Cogitare? Hic invenio: cogitatio est, haec sola a me divelli nequit. Ego sum, ego existo; certum est. [... ] Nihil nunc admitto nisi quod necessario sit verum: sum igitur praecise tantum res cogitans, id est, mens, sive animus, sive intellectus, sive ratio, voces mihi prius significationis ignotae. Sum autem res vera, \& vere existens, sed qualis res? Dixi, cogitans” (Descartes, Meditationes, Meditatio II, p. 27; my italics; see also pp. 28 f. [Descartes, Meditations, pp. 19 f.], but also 


\section{[...]}

I am a thing that thinks: that is, a thing that doubts, affirms, denies, understands a few things, is ignorant of many things, is willing, is unwilling, and also which imagines and has sensory perceptions; [...] even though the objects of my sensory experience and imagination may have no existence outside me, nonetheless the modes of thinking which I refer to as cases of sensory perception and imagination, in so far as they are simply modes of thinking, do exist within me - of that I am certain. [. . . I am certain that I am a thinking thing. ${ }^{178}$

Such cognitive certainty, however, presupposes the rejection of the 'demon hypothesis. ${ }^{, 179}$ Only under the premise of a metaphysical assurance of the existence of a perfect, almighty, and, in particular, benevolent God, who acts as guarantor

the Second Meditation altogether (Descartes, Meditationes, pp. 23-34; Descartes, Meditations, pp. 16-23).

178 Descartes, Meditations, p. 24; my italics. "Ego sum res cogitans, id est dubitans, affirmans, negans, pauca intelligens, multa ignorans, volens, nolens, imaginans etiam \& sentiens; ut enim ante animadverti, quamvis illa quae sentio vel imaginor extra me fortasse nihil sint, illos tamen cogitandi modos, quos sensus \& imaginationes appello, quatenus cogitandi quidam modi tantum sunt, in me esse sum certus. [...] Sum certus me esse rem cogitantem" (Descartes, Meditationes, Meditatio III 'De Deo, quod existat,' pp. 34 f.). This is the beginning of the Third Meditation ('The existence of God'), which takes up the results of the second (“[...] nam cum mihi nunc notum sit ipsamet corpora non proprie a sensibus, vel ab imaginandi facultate, sed a solo intellectu percipi, nec ex eo percipi quod tangantur aut videantur, sed tantum ex eo quod intelligantur, aperte cognosco nihil facilius aut evidentius mea mente posse a me percipi” [Descartes, Meditationes, Meditatio II, p. 34]/“I now know that even bodies are not strictly perceived by the senses or the faculty of imagination but by the intellect alone, and that this perception derives not from their being touched or seen but from their being understood; and in view of this I know plainly that I can achieve an easier and more evident perception of my own mind than of anything else" [Descartes, Meditations, Second Meditation, pp. 22 f.]).

179 See Descartes, Meditationes, Meditatio III, pp. 35 f.; Descartes, Meditations, p. 25. (After recalling that the doubt about mathematical truths is based on the hyperbolic doubt of the 'genius malignus-argument,' it reads: “Et certe cum nullam occasionem habeam existimandi aliquem Deum esse deceptorem, nec quidem adhuc satis sciam utrum sit aliquis Deus, valde tenuis \&, ut ita loquar, Metaphysica dubitandi ratio est, quae tantum ex ea opinione dependet. Ut autem etiam illa tollatur, quamprimum occurret occasio, examinare debeo an sit Deus, \&, si sit, an possit esse deceptor; hac enim re ignorata, non videor de ulla alia plane certus esse unquam posse” [Descartes, Meditationes, p. 36]/“And since I have no cause to think that there is a deceiving God, and I do not yet even know for sure whether there is a God at all, any reason for doubt which depends simply on this supposition is a very slight and, so to speak, metaphysical one. But in order to remove even this slight reason for doubt, as soon as the opportunity arises I must examine whether there is a God, and, if there is, whether he can be a deceiver. For if I do not know this, it seems that I can never be quite certain about anything else” [Descartes, Meditations, p. 25]). 
of truth, can the basis of knowledge be guaranteed. ${ }^{180}$ The guarantee for building objective knowledge is provided by the 'rational ideas' given by God and in particular by the 'clear and distinct' concepts of mathematics and logic. As the meditator determines, after having reassured himself of his own (thinking) existence (itself the result of doubt), only that which can be grasped entirely "clearly and distinctly" ("clare \& distincte") has a claim to truth. ${ }^{181}$ And in contrast to the 'ideas coming from outside' ("ideae adventitiae") and the 'self-generated ideas' ("ideae me ipso factae"), only the "innate ideas" ("ideae innatae") received directly from God, fulfill this claim. ${ }^{182}$ A further axiom of the system of rational

180 See the proofs of God's existence in the third (Meditatio III 'De Deo, quod existat'/'The existence of God') and fifth meditation (Meditatio V 'De rerum materialium; \& iterum de Deo, quod existat'/'The essence of material things, and the existence of God considered a second time'), which, however, shall not be explained here in more detail (cf. esp. Descartes, Meditationes, pp. 41-52 and pp. 65-71; Descartes, Meditations, pp. 28-35 and pp. 45-49), as well as, among other things, regarding the compatibility of error with the idea of a perfect and benevolent God: Meditatio IV 'De vero \& falso'/'Truth and falsity' (cf. esp. Descartes, Meditationes, pp. 54-62; Descartes, Meditations, pp. 38-43). (Cf. e.g.: "In primis enim agnosco fieri non posse ut ille me unquam fallat; in omni enim fallacia vel deceptione aliquid imperfectionis reperitur; \& quamvis posse fallere, nonnullum esse videatur acuminis, aut potentiae argumentum, proculdubio velle fallere, vel malitiam vel imbecillitatem testatur, nec proinde in Deum cadit [Descartes, Meditationes, p. 53]/“To begin with, I recognize that it is impossible that God should ever deceive me. For in every case of trickery or deception sorne imperfection is to be found; and although the ability to deceive appears to be an indication of cleverness or power, the will to deceive is undoubtedly evidence of malice or weakness, and so cannot apply to God" [Descartes, Meditations, p. 37]; "Atque ita plane video omnis scientiae certitudinem \& veritatem ab una veri Dei cognitione pendere, adeo ut, priusquam illum nossem, nihil de ulla alia re perfecte scire potuerim" [Meditationes, p. 71]/“Thus I see plainly that the certainty and truth of all knowledge depends uniquely on my awareness of the true God, to such an extent that I was incapable of perfect knowledge about anything else until I became aware of him” [Meditations, p. 49]).

181 " [...] ac proinde jam videor pro regula generali posse statuere, illud omne esse verum, quod valde clare \& distincte percipio” (Descartes, Meditationes, p. 35)/“So I now seem to be able to lay it down as a general rule that whatever I perceive very clearly and distinctly is true" (Descartes, Meditations, p. 24); cf. as well the formulation of the 'rule of evidence' in the Discours, the first of the four rules of understanding set up there (Descartes, Discours de la méthode II, 7 [cf. note 100], p. 18; Descartes, Discourse on the Method [cf. note 100], p. 120 [followed by: 'rule of decomposition,' 'rule of order,' 'rule of completeness']), see also the further explanation of 'clare et distincte' in the sixth meditation (Descartes, Meditationes [cf. note 161], p. 78; Descartes, Meditations [cf. note 161], p. 54); see also the broader thematization of this aspect in connection with the discussion of La vida es sueño later in this study (chap. 3.1).

182 Regarding the ideae innatae, see in particular the third meditation (Descartes, Meditationes, pp. 34-52, esp. pp. 37-40; Descartes, Meditations, pp. 24-36, esp. pp. 26 f.; cf., furthermore, Meditationes, pp. 68-71 and pp. 78 ff.; Meditations, pp. $47 \mathrm{ff}$. and pp. 54 f.); for the aspect of the assured certainty of the innate 'clear' mathematical categories, cf., e.g., Meditationes, p. 43; 
cognition constitutes the strict separation of mind (res cogitans) and body (res extensa), of reason and sensory perception. ${ }^{183}$ Knowledge about the material world,

Meditations, pp. 29 f. ('extension in length, breadth and depth,' 'motion,' 'duration,' 'number,' etc.) and Meditationes, pp. 63 ff.; Meditations, pp. 44 f. (e.g., 'the idea of the triangel'; moreover: "meminique me semper [...] ejusmodi veritates, quae nempe de figuris, aut numeris, aliisve ad Arithmeticam, vel Geometriam, vel in genere ad puram atque abstractam Mathesim pertinentibus, evidenter agnoscebam, pro omnium certissimis habuisse” [Meditationes, p. 65]/“I also remember that [...] I always held that the most certain truths of all were the kind which I recognized clearly in connection with shapes, or numbers or other items relating to arithmetic or geometry, or in general to pure and abstract mathematics" [Meditations, p. 45]) as well as the following above. (For the mentioned classification of ideas, cf.: "Ex his autem ideis aliae innatae, aliae adventitiae, aliae a me ipso factae mihi videntur: nam quod intelligam quid sit res, quid sit veritas, quid sit cogitatio, haec non aliunde habere videor quam ab ipsamet mea natura; quod autem nunc strepitum audiam, solem videam, ignem sentiam, a rebus quibusdam extra me positis procedere hactenus judicavi; ac denique Syrenes, Hyppogryphes, \& similia a me ipso finguntur” [Meditationes, pp. 37 f.; my italics]/“Among my ideas, some appear to be innate, some to be adventitious, and others to have been invented by me. My understanding of what a thing is, what truth is, and what thought is, seems to derive simply from my own nature. But my hearing a noise, as I do now, or seeing the sun, or feeling the fire, comes from things which are located outside me, or so I have hitherto judged. Lastly, sirens, hippogriffs and the like are my own invention" [Meditations, p. 26; my italics]; for the 'first innate idea,' cf.: "idea[e] vera[e] mihi ingenita[e], quarum prima \& praecipua est idea Dei” [Meditationes, p. 68]/“the true ideas which are innate in me, of which the first and most important is the idea of God" [Meditations, p. 24]; on the aspect of the God given ratio, the innate ability to grasp the evident, cf.: "[. . .] nam quaecumque lumine naturali mihi ostenduntur, ut quod ex eo quod dubitem, sequatur me esse, \& similia, nullo modo dubia esse possunt, quia nulla alia facultas esse potest, cui aeque fidam ac lumini isti, quaeque illa non vera esse possit docere" [Meditationes, pp. 38f]/“Whatever is revealed to me by the natural light - for example that from the fact that I am doubting it follows that I exist, and so on - cannot in any way be open to doubt. This is because there cannot be another faculty both as trustworthy as the natural light and also capable of showing me that such things are not true" [Meditations, p. 27]).

183 Cf. for this esp. the explanation in Meditatio V 'De rerum materialium; \& iterum de Deo, quod existat'/'The essence of material things, and the existence of God considered a second time' and Meditatio VI 'De rerum materialium existentia, \& reali mentis a corpore distinctione'/'The existence of material things, and the real distinction between mind and body' (Descartes, Meditationes, pp. 63-90, esp. pp. 78-81; Descartes, Mediations, pp. 44-62, esp. pp. 54 ff. [e.g.: "Et quamvis fortasse (...) habeam corpus, quod mihi valde arcte conjunctum est, quia tamen ex una parte claram \& distinctam habeo ideam mei ipsius quatenus sum tantum res cogitans, non extensa, \& ex alia parte distinctam ideam corporis, quatenus est tantum res extensa, non cogitans, certum est me a corpore meo revera esse distinctum, \& absque illo posse existere"/“It is true that I may have (...) a body that is very closely joined to me. But nevertheless, on the one hand I have a clear and distinct idea of myself, in so far as I am simply a thinking, non-extended thing; and on the other hand I have a distinct idea of body, in so far as this is simply an extended, non-thinking thing. And accordingly, it is certain that I am really distinct from my body, and can exist without it”]; Meditationes, pp. 85 f.; Meditations, 
whose existence is now guaranteed by the non-deceptive God, can only be obtained through reason, the recognition of rational-mathematically translatable structures. ${ }^{184}$ After having established the certainty of reason and the explanatory model of the world based on it, the sixth Meditation undertakes a revision of the doubts expressed in the first Meditation: the senses may deceive, but not always (“[...] non quidem omnia, quae habere videor a sensibus, puto esse temere admittenda; sed neque etiam omnia in dubium revocanda"). ${ }^{185}$ Here, once again Descartes rejects traditional (Aristotelian) epistemology that maintains that the experience of sensory perception could serve as the first, secure basis for knowledge. Sensory perception must first

p. 59 [the body is divisible, the mind indivisible]; for the determination of the ego as a 'thinking substance,' cf. in addition to what has just been quoted further the above ['Ego sum res cogitans'; 'Sum certus me esse rem cogitantem'] as well as, among others: “[. .. ] ego, qui nihil aliud sum quam res cogitans [...]” [Meditationes, p. 81]/“[...] I, who am nothing but a thinking thing [...]" [Meditations, p. 56]). It should be noted that, even though Cartesian metaphysics is still essentially based on the authority of God, the paradigm of a strict separation of reason and physis holds highly problematic theological implications, not least of which was the accusation of the incompatibility of substance theory with the central Catholic dogma of transubstantiation, which ultimately led to a ban on his writings. They were placed on the Index of Forbidden Books, introduced in 1559 by the Tridentinum, on November 20th 1663 (thirteen years after his death) (cf. Index Librorum prohibitorum, ed. Pope Alexander VII, Rome 1664, pp. 393b-394a and p. 396; cf. also the discussions on the topic of the Eucharist in the Objectiones et Responsiones [Descartes, Meditationes (cf. note 161), pp. 217 f. (Objectiones Quartae, pp. 196-218) and pp. 248-256 (Responsio ad Quartas Objectiones, pp. 218-256); Descartes, Meditations (cf. note 161), pp. 152 f. (Forth Set of Objections, pp. 138-153) and pp. 173-178 (Author's Replies to the Fourth Set of Objections, pp. 154-178)]). Thirteen years later, in 1676, Montaigne's Essais were indexed, but interestingly enough, the writings of Sextus Empiricus were not.

184 "Non tamen forte omnes [res corporeae] tales omnino existunt, quales illas sensu comprehendo, quoniam ista sensuum comprehensio in multis valde obscura est \& confusa; sed saltem illa omnia in iis sunt, quae clare \& distincte intelligo, id est omnia generaliter spectata, quae in purae Matheseos objecto comprehenduntur" (Descartes, Meditationes, p. 80; see as well Meditationes, p. 71)/“They [corporeal things] may not all exist in a way that exactly corresponds with my sensory grasp of them, for in many cases the grasp of the senses is very obscure and confused. But at least they possess all the properties which I clearly and distinctly understand, that is, all those which, viewed in general terms, are comprised within the subject-matter of pure mathematics” (Descartes, Meditations, p. 55; see as well p. 49).

185 Descartes, Meditationes, pp. 77 f. (“[ . . ] although I do not think I should heedlessly accept everything I seem to have acquired from the senses, neither do I think that everything should be called into doubt” [Descartes, Meditations, p. 54]). 
undergo the 'prior examination by the intellect' - i.e. be compared with the ideae innatae, the 'mathematizability' - in order to be considered reliable, to be grasped as 'clear and distinct.'186

Radical doubt shook and then collapsed the foundations of existing certainties in order to build on the newly uncovered foundation of reliable knowledge; namely, the doubting person's own certainty of being. This new certainty of knowledge, i.e., rationalism, is then denied its actual effective power at the end of the Meditationes. In order to recognize and avoid errors based on sensory perception, the various senses serve as a means of comparison, with memory and the mind available as suitable instruments. ${ }^{187}$ Coherence, continuity, and order are determined as adequate criteria for distinguishing between false and unproblematic sensory perceptions. The previously expressed "exaggerated

186 Cf.: “[. . .] Ideoque haec natura docet quidem ea refugere quae sensum doloris inferunt, \& ea prosequi quae sensum voluptatis, \& talia; sed non apparet illam praeterea nos docere ut quicquam ex istis sensuum perceptionibus sine praevio intellectus examine de rebus extra nos positis concludamus, quia de iis verum scire ad mentem solam, non autem ad compositum videtur pertinere [...]” (Descartes, Meditationes, pp. 82 f.; my italics)/“My nature [what God has bestowed on me as a combination of mind and body], then, [. . .] does indeed teach me to avoid what induces a feeling of pain and to seek out what induces feelings of pleasure, and so on. But it does not appear to teach us to draw any conclusions from these sensory perceptions about things located outside us without waiting until the intellect has examined the matter. For knowledge of the truth about such things seems to belong to the mind alone, not to the combination of mind and body" (Descartes, Meditations, p. 57; my italics); on the aspect of 'mathematization,' see above note 184; for the referring to traditional epistemology, which is then replaced by the 'rationalistic system,' cf.: “Atque etiam quia recordabar me prius usum fuisse sensibus quam ratione, videbamque ideas quas ipse effingebam non tam expressas esse, quam illae erant quas sensu percipiebam, \& plerumque ex earum partibus componi, facile mihi persuadebam nullam plane me habere in intellectu, quam non prius habuissem in sensu” (Meditationes, p. 75)/“In addition, I remembered that the use of my senses had come first, while the use of my reason came only la ter; and I saw that the ideas which I formed myself were less vivid than those which I perceived with the senses and were, for the most part, made up of elements of sensory ideas. In this way. I easily convinced myself that I had nothing at all in the intellect which I had not previously had in sensation" (Meditations, p. 52). 187 Furthermore, all the senses, as far as what is beneficial to the body, more often gave true than false information: "Nam sane, cum sciam omnes sensus circa ea, quae ad corporis commodum spectant, multo frequentius verum indicare quam falsum, possimque uti fere semper pluribus ex iis ad eandem rem examinandam, \& insuper memoria, quae praesentia cum praecedentibus connectit, \& intellectu, qui jam omnes errandi causas perspexit; [...]” (Descartes, Meditationes, p. 89; my italics)/“For I know that in matters regarding the well-being of the body, all my senses report the truth much more frequently than not. Also, I can almost always make use of more than one sense to investigate the same thing; and in addition, I can use both my memory, which connects present experiences with preceding ones, and my intellect, which has by now examined all the causes of error" (Descartes, Meditations, p. 61). 
doubts" ("hyperbolicae [...] dubitationes") would thus have to be rejected, moreover, they would be downright "laughable" ("risu dignae"). This applies particularly to: "[...] the principal reason for doubt, namely my inability to distinguish between being asleep and being awake." ${ }^{" 188}$ Descartes then refutes the skeptical 'dream trope' by using the argument of continuity:

For I now notice that there is a vast difference between the two [being asleep and being awake], in that dreams are never linked by memory with all the other actions of life as waking experiences are. If, while I am awake, anyone were suddenly to appear to me and then disappear immediately, as happens in sleep, so that I could not see where he had come from or where he had gone to, it would not be unreasonable for me to judge that he was a ghost, or a vision created in my brain, rather than a real man. But when I distinctly see where things come from and where and when they come to me, and when I can connect my perceptions of them with the whole of the rest of my life without a break, then I am quite certain that when I encounter these things I am not asleep but awake. $^{189}$

The examination of the connection between current perceptions and previous life experiences can provide reliable information about whether one is awake or dreaming, since continuity in this respect can only be consistent with the waking state. The clarity of the nexus provides the evidence. Under the axiomatic conditions of the distinction between reason and sensory perception and the existence of a benevolent God, who guarantees the reality of the outside world and ensures the reliable functioning of reason, dream and reality are kept explicitly distinct. Descartes then continues:

And I ought not to have even the slightest doubt of their reality if, after calling upon all the senses as well as my memory and my intellect in order to check them, I receive no

188 Descartes, Meditations, p. 61; “[. . . ] non amplius vereri debeo ne illa, quae mihi quotidie a sensibus exhibentur, sint falsa, sed hyperbolicae superiorum dierum dubitationes, ut risu dignae, sunt explodendae. Praesertim summa illa de somno, quem a vigilia non distinguebam" (Descartes, Meditationes, p. 89).

189 Descartes, Meditations, pp. $61 \mathrm{f}$. "[N]unc enim adverto permagnum inter utrumque esse discrimen, in eo quod nunquam insomnia cum reliquis omnibus actionibus vitae a memoria conjungantur, ut ea quae vigilanti occurunt; nam sane, si quis, dum vigilo, mihi derepente appareret, statimque postea dispareret, ut fit in somnis, ita scilicet, ut nec unde venisset, nec quo abiret, viderem, non immerito spectrum potius, aut phantasma in cerebro meo effictum, quam verum hominem esse judicarem. Cum vero eae res occurrunt, quas distincte, unde, ubi, \& quando mihi adveniant, adverto, earumque perceptionem absque ulla interruptione cum tota reliqua vita connecto, plane certus sum, non in somnis, sed vigilanti occurrere" (Descartes, Meditationes, pp. 89 f.). 
conflicting reports from any of these sources. For from the fact that God is not a deceiver it follows that in cases like these I am completely free from error. ${ }^{190}$

And it is this very aspect mentioned again here - the authority of God to whom man owes the 'innate ideas' that enable him to achieve a reliable perception of the material world based on mathematical understanding - that gives the epistemological project of this 'Father of Modernity' a 'pre-modern' impulse. The change of perspectives in Descartes' line of thought, however, points to philosophical modernity, for the focus is not on the knowledge of the very nature of things themselves, but on the self-assurance of thinking, the methodical backing of one's own thinking processes. The anchoring of knowledge in reason makes recourse to authority-related knowledge obsolete, and inextricably detaches itself from traditional epistemology. In Descartes' work, the path to this 'new beginning' is not an explicit engagement with authority and tradition, but rather in the form of 'meditation' and an engagement with skepticism. However, Descartes' view inwards, to the self, is not that the introspection of Montaigne; it is epistemologically motivated. Radical skeptical doubt serves to establish the foundation of subjective, and, ultimately, objective certainty. In contrast to the Early Modern skeptics Montaigne and Sánchez, Descartes' reception of ancient Pyrrhonism is not affirmative; rather, the hyperbolic doubt of the Meditationes serves as a rhetorical volte to create a foundation of certainty that ultimately cannot be logically demonstrated. Cartesian rationalism, based on methodical reference to skepticism, is not a refutation of skepticism, of doubt about the reliability of sensory perception.

190 Descartes, Meditations, p. 62. "Nec de ipsarum veritate debeo vel minimum dubitare, si, postquam omnes sensus, memoriam \& intellectum ad illas examinandas convocavi, nihil mihi quod cum caeteris pugnet, ab ullo ex his nuntietur. Ex eo enim quod Deus non sit fallax, sequitur omnino in talibus me non falli" (Descartes, Meditationes, p. 90). It should be noted that in the following sentence, which concludes the Meditationes, the theoretical character is again emphasized. Even if the possibility of certain knowledge is theoretically guaranteed, in practical, everyday life errors can occur after all, which is ultimately all too human. Implicitly, the aspect which Descartes emphasizes in several places is also mentioned again, namely, that the methodical doubt can not be transferred to the realm of action, the 'res agendae' ("Sed quia rerum agendarum necessitas non semper tam accurati examinis moram concedit, fatendum est humanam vitam circa res particulares saepe erroribus esse obnoxiam, \& naturae nostrae infirmitas est agnoscenda” [Meditationes, p. 90]/“But since the pressure of things to be done does not always allow us to stop and make such a meticulous check, it must be admitted that in this human life we are often liable to make mistakes about particular things, and we must acknowledge the weakness of our nature" [Meditations, p. 62]). 